Supporting Information for

\title{
Superfast tetrazole-BCN cycloaddition reaction for bioorthogonal protein labeling on live cells
}

\section{Gangam Srikanth Kumar, Stefano Racioppi, Eva Zurek, and Qing Lin*}

Department of Chemistry, State University of New York at Buffalo, Buffalo, New York 14260-3000,

United States

*Email: qinglin@buffalo.edu

\section{Table of Contents}

Supplemental Figures and Tables

Figure S1. Calculated SlogP and LogS values for the sterically shielded tetrazoles.................................S2

Figure S2. HPLC traces of Boc- and $\mathrm{CF}_{3}$-substituted tetrazoles and sulfonated tetrazoles 1-6 .........S3-S4

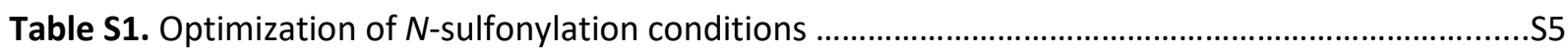

Table S2. Crystal data and structure refinement for tetrazole 1...........................................................S6

Table S3. Product distributions for the photoclick reactions of sulfonated tetrazoles with an equimolar mixture of acrylamide and glutathione in phosphate buffer/acetonitrile (1:1) ........................... S7-S14

Figure S3. Determining half-life of the nitrile imine photogenerated from tetrazole 1...................... S15

Figure S4. Survey of photoclick reactions of tetrazole 1 with various dipolarophiles.....................S16-S19

Figures S5-S10. Kinetics determination of the reactions between tetrazole 1-6 and Sph............ S20-S25

Figures S11-S16. Comparison of BCN reactivity to Sph in the photoclick reactions........................S26-S31

Table S4. Activation strain analysis of the strain-promoted cycloaddition reactions........................... S32

Figure S17. QTOF-LC/MS analysis of unmodified lysozyme and BCN modification of lysozyme after incubation with BCN-OCOO-PNP.

Figure S18. QTOF-LC/MS analysis of lyso-BCN conjugate and unmodified lysozyme after photoclick reaction with tetrazole 1 .

Figure S19. Bioorthogonal labeling of GCGR on HEK 293T cells via photoclick chemistry......

Figure S20. Confocal micrographs of HEK 293T cells expressing BCNK or BocK-encoded GCGR-GFP after photoclick chemistry with tetrazole 7

Figure S21. Confocal micrographs of HEK 293T cells expressing GCGR-H372SphK/BCNK-GFP after photoclick chemistry with tetrazole 7 . S38

Figure S22. Determination of quantum yield for photoinduced ring rupture of tetrazole $\mathbf{1}$ using the potassium ferrioxalate-based chemical actinometer S39

General Information S40

Experimental Procedures and Characterization Data. S40-S48

Computational Details 548

References S48-S49

${ }^{1} \mathrm{H}$ and ${ }^{13} \mathrm{C}$ NMR Spectra S50-S64 Computed Structures (Figures S23-S30) and Cartesian Coordinates S65-S85 
a)

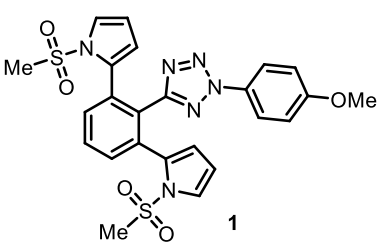

$\mathrm{S} \log \mathrm{P}=2.8903$

LogS $=-5.7004$
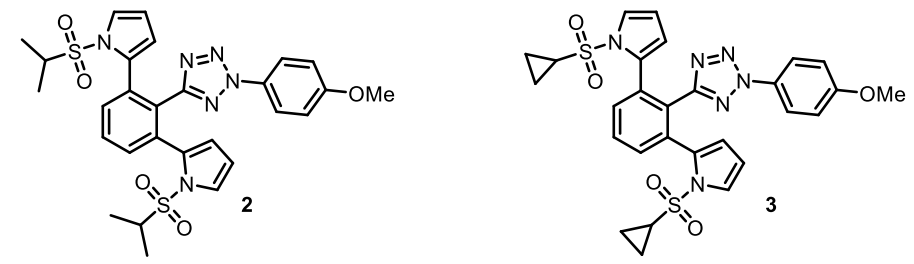

$S \log P=4.4475$

LogS $=-7.0092$

$\mathrm{S} \log \mathrm{P}=3.9555$

LogS $=-6.8051$
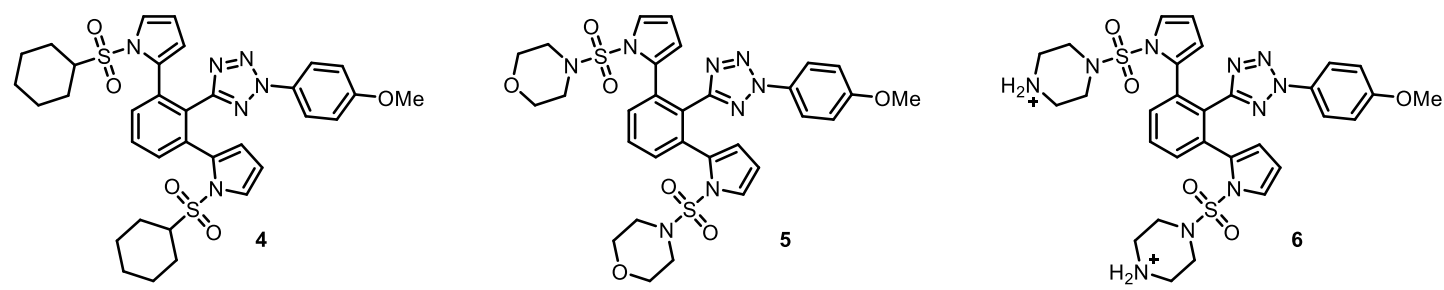

$\mathrm{S} \log \mathrm{P}=6.2961$

LogS $=-8.6426$

$\mathrm{S} \log \mathrm{P}=3.9619$

LogS $=-7.5970$

Slog $\mathrm{P}=1.0555$

LogS $=-6.7560$

b)
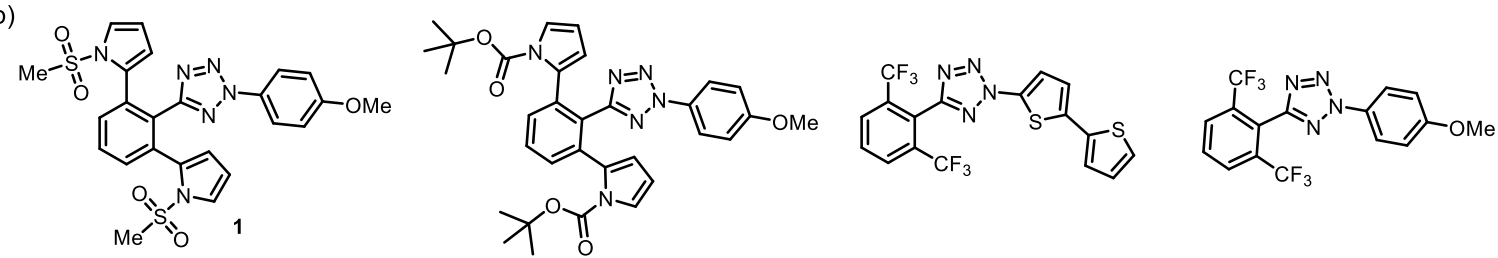

$\mathrm{S} \log \mathrm{P}=2.8903$

LogS $=-5.7004$

$S \log P=6.8413$

LogS $=-8.1467$

Slog $P=6.7799$

LogS $=-7.8348$

$\mathrm{S} \log \mathrm{P}=4.9985$

LogS $=-5.9025$

Figure S1. Calculated SlogP and LogS values for the sterically shielded tetrazoles. (a) Calculated SlogP (for lipophilicity) and LogS (for water solubility) values for the designed sulfonated tetrazoles; (b) Comparision of SlogP and LogS values for sulfonated tetrazole 1, Boc-substituted tetrazole, ${ }^{1}$ and $\mathrm{CF}_{3^{-}}$ substituted tetrazoles. ${ }^{2}$ SlogP and LogS values were calculated following a literarure report. ${ }^{3}$ 

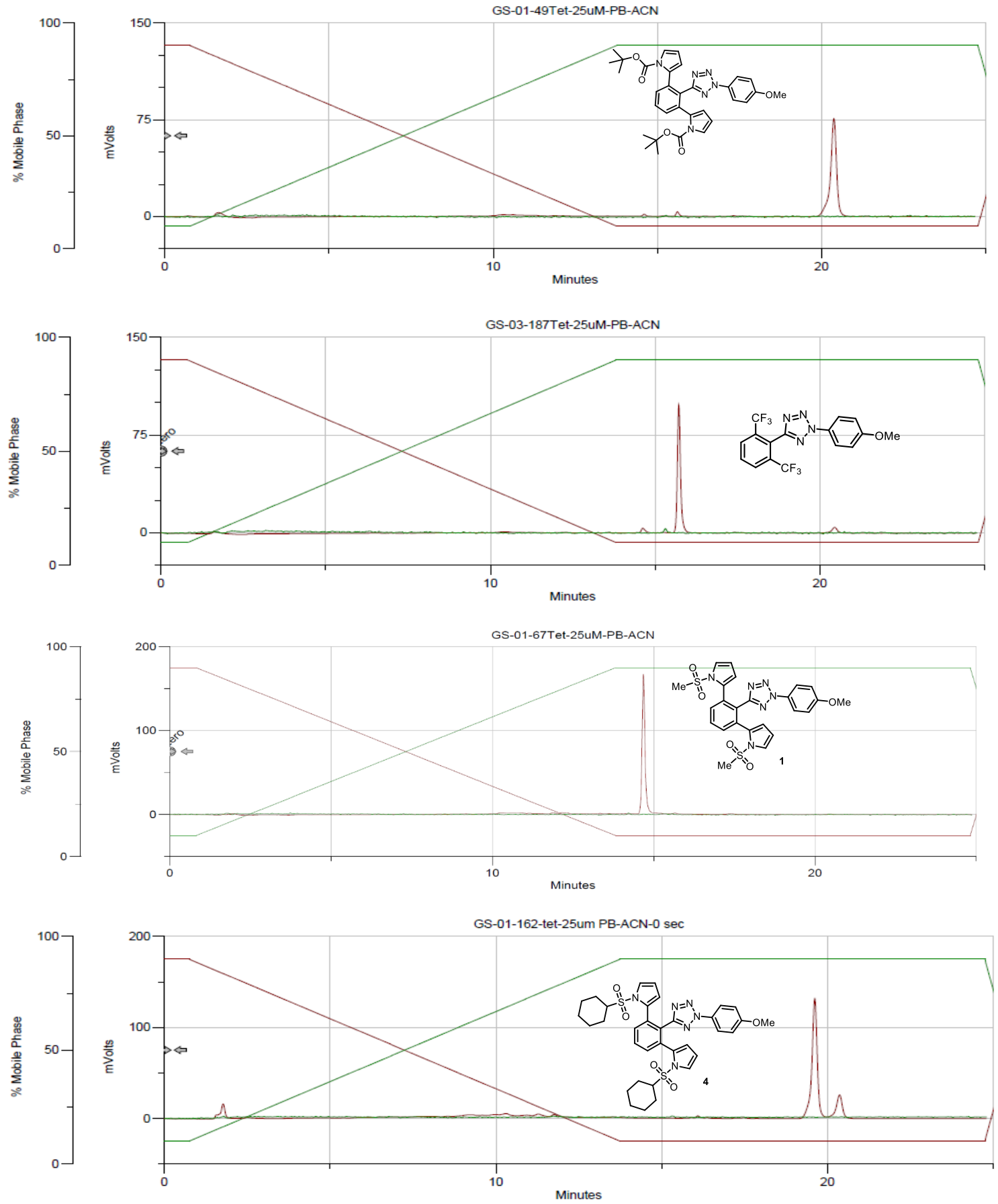

S3 

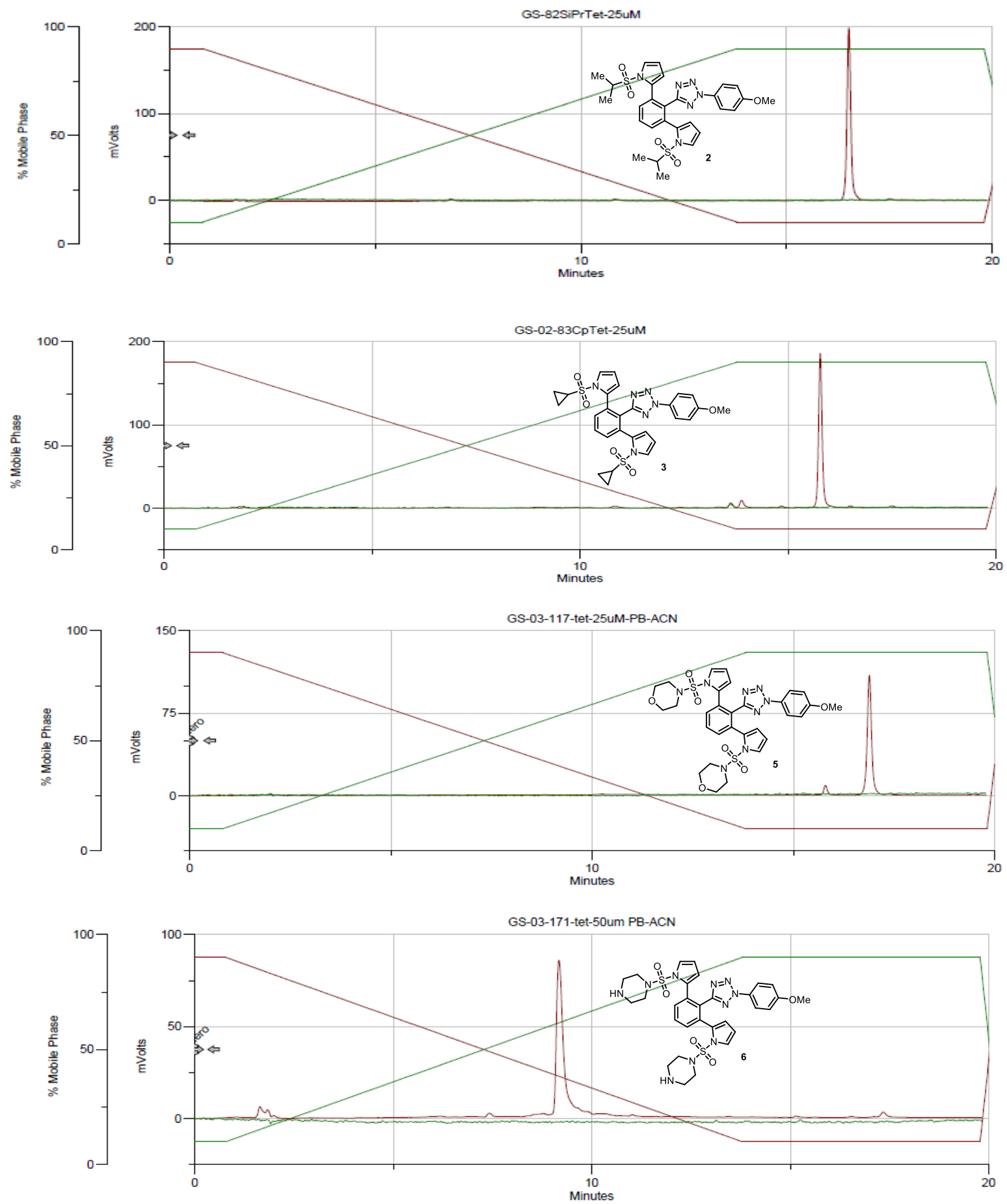

Figure S2. HPLC traces of Boc-substituted tetrazole, and $\mathrm{CF}_{3}$-substituted tetrazole and sulfonated tetrazoles 1-6. The shortest retention time of terazole $\mathbf{1}$ and $\mathbf{6}$ indicates highest polarity and greatest water solubility. Red trace $=$ absorbance at $254 \mathrm{~nm}$; green trace $=$ absorbance at $370 \mathrm{~nm}$. 
Table S1. Optimization of $N$-sulfonylation conditions ${ }^{a}$

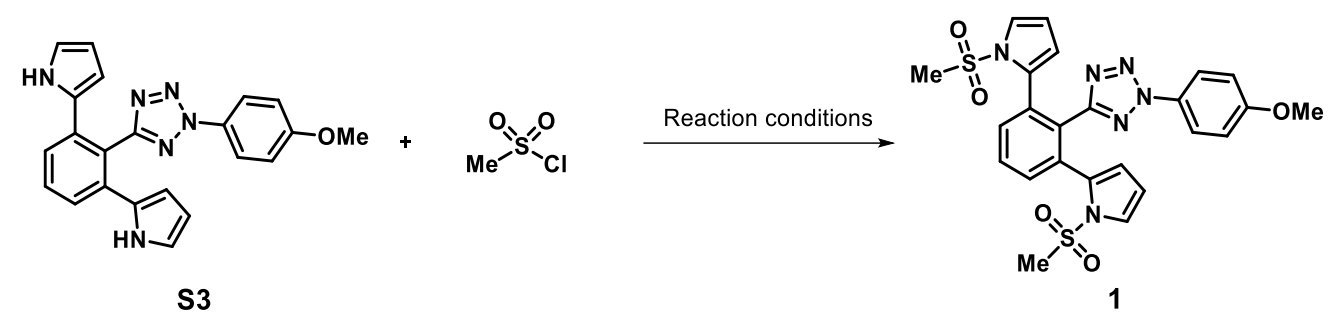

\begin{tabular}{|c|c|c|}
\hline Entry & Conditions & Results \\
\hline 1 & $\begin{array}{l}\mathrm{KOH} \text { ( } 25 \text { equiv), } \mathrm{Bu}_{4} \mathrm{NHSO}_{4} \text { ( } 0.2 \text { equiv), } \mathrm{MsCl} \text { (4 equiv), DCM, } \\
\mathrm{rt}, 5 \mathrm{~h}\end{array}$ & Messy reaction \\
\hline 2 & $\mathrm{NaH}$ (3.0 equiv), $\mathrm{MsCl}$ (3 equiv), DMF, $\mathrm{rt}, 12 \mathrm{~h}$ & S.M. remained unreacted \\
\hline 3 & $\begin{array}{l}\mathrm{LiOH} \text { (5 equiv), } \mathrm{Bu}_{4} \mathrm{NHSO}_{4} \text { ( } 0.1 \text { equiv), } \mathrm{MsCl} \text { ( } 3 \text { equiv), } \mathrm{DCM}, \mathrm{rt} \text {, } \\
12 \mathrm{~h}\end{array}$ & S.M. remained unreacted \\
\hline 4 & $n$-BuLi (5.0 equiv), $\mathrm{MsCl}$ (5.0 equiv), THF, $-20^{\circ} \mathrm{C} \rightarrow \mathrm{rt}, 12 \mathrm{~h}$ & Trace amount of product ${ }^{b}$ \\
\hline 5 & $\mathrm{NaH}$ (3.0 equiv), $\mathrm{MsCl}$ (3 equiv), THF, rt, $12 \mathrm{~h}$ & S.M. remained unreacted \\
\hline 7 & $\mathrm{DBU}$ (3.0 equiv), $\mathrm{MsCl}$ (3 equiv), DCM, rt, $12 \mathrm{~h}$ & S.M. remained unreacted \\
\hline 8 & $\mathrm{KO}^{\mathrm{t}} \mathrm{Bu}$ (5.0 equiv), $\mathrm{MsCl}$ (5 equiv), THF, $0^{\circ} \mathrm{C}-\mathrm{rt}, 24-48 \mathrm{~h}$ & $18 \%^{b}$ \\
\hline
\end{tabular}

${ }^{a}$ The reaction was performed on $0.075 \mathrm{mmol}$ scale. ${ }^{b} \mathrm{~A}$ mixture of $\mathrm{C}-2$ and $\mathrm{C}-3$ sulfonated products was obtained along with the desired product. 
Table S2. Crystal data and structure refinement for tetrazole 1

\begin{tabular}{|c|c|}
\hline Empirical formula & $\mathrm{C}_{24} \mathrm{H}_{22} \mathrm{~N}_{6} \mathrm{O}_{5} \mathrm{~S}_{2}$ \\
\hline Formula weight & 538.59 \\
\hline Temperature/K & 90.0 \\
\hline Crystal system & triclinic \\
\hline Space group & P-1 \\
\hline $\mathrm{a} / \AA ̊$ & $11.6937(4)$ \\
\hline$b / \AA$ & $14.5993(5)$ \\
\hline$c / \AA ̊$ & $15.9912(5)$ \\
\hline$\alpha /^{\circ}$ & $68.3950(10)$ \\
\hline$\beta /{ }^{\circ}$ & $85.1140(10)$ \\
\hline$\gamma / /^{\circ}$ & $76.9150(10)$ \\
\hline Volume/Å3 & $2472.31(14)$ \\
\hline Z & 4 \\
\hline pcalcg/cm3 & 1.447 \\
\hline$\mu / m m-1$ & 0.264 \\
\hline$F(000)$ & 1120.0 \\
\hline Crystal size/mm3 & $0.05 \times 0.04 \times 0.04$ \\
\hline Radiation & $\operatorname{MoK} \alpha(\lambda=0.71073)$ \\
\hline $2 \Theta$ range for data collection $/^{\circ}$ & 3.07 to 63.656 \\
\hline Index ranges & $-17 \leq h \leq 17,-21 \leq k \leq 21,-23 \leq \mathrm{I} \leq 23$ \\
\hline Reflections collected & 62464 \\
\hline Independent reflections & $16924[$ Rint $=0.0534$, Rsigma $=0.0514]$ \\
\hline Data/restraints/parameters & $16924 / 50 / 762$ \\
\hline Goodness-of-fit on F2 & 1.035 \\
\hline Final $R$ indexes $[\mid>=2 \sigma(I)]$ & $\mathrm{R} 1=0.0490, w R 2=0.1126$ \\
\hline Final $R$ indexes [all data] & $R 1=0.0673, w R 2=0.1210$ \\
\hline Largest diff. peak/hole / e Å-3 & $0.71 /-0.95$ \\
\hline
\end{tabular}


Table S3. Product distributions for the photoclick reactions of sulfonated tetrazoles with an equimolar mixture of acrylamide and glutathione in phosphate buffer/acetonitrile $(1: 1)^{a}$

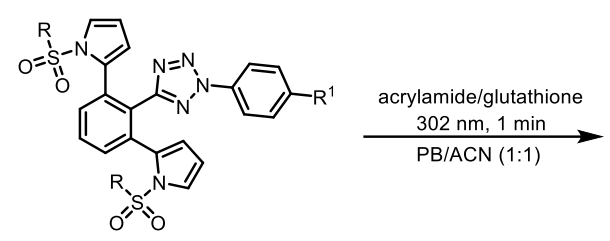

1-6

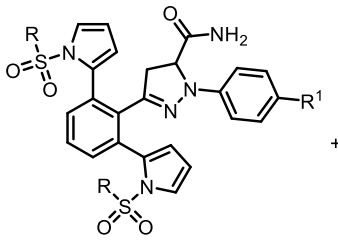

cycloadduct A

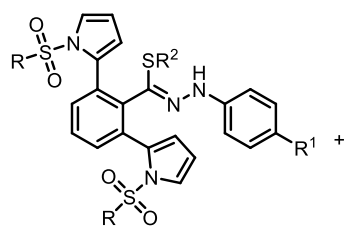

GSH adduct B

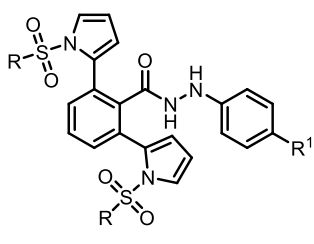

$\mathrm{H}_{2} \mathrm{O}$ adduct $\mathrm{C}$

\begin{tabular}{|c|c|c|c|c|}
\hline \multirow{2}{*}{ Entry } & \multirow{2}{*}{ Tetrazole } & \multicolumn{3}{|c|}{ Product distribution (\%) $)^{b}$} \\
\hline & & $A$ & B & $\mathrm{C}$ \\
\hline 1 & $1: R=M e ; R^{1}=O M e$ & 88 & 6 & 6 \\
\hline 2 & 2: $R=\stackrel{\mathrm{i}}{\mathrm{Pr}} ; \mathrm{R}^{1}=\mathrm{OMe}$ & 89 & 7 & 5 \\
\hline 3 & 3: $\mathrm{R}=$ cyclopropyl; $\mathrm{R}^{1}=\mathrm{OMe}$ & 90 & 4 & 6 \\
\hline 4 & 4: $R=$ cyclohexyl; $R^{1}=O M e$ & 90 & trace & 8 \\
\hline 5 & 5: $R=$ morpholine; $R^{1}=O B n$ & 92 & trace & 6 \\
\hline $6^{c}$ & 6: $R=$ piperazine; $R^{1}=O B n$ & 75 & trace & 10 \\
\hline
\end{tabular}

${ }^{a} \mathrm{~A}$ solution of $25 \mu \mathrm{M}$ sulfonated tetrazole and $500 \mu \mathrm{M}$ each of acrylamide and glutathione (GSH, reduced form) in $500 \mu \mathrm{L}$ phosphate buffer/acetonitrile (1:1), pH 7.4, was irradiated with a handheld 302-nm UV lamp at room temperature for $1 \mathrm{~min} .{ }^{b}$ The product distribution was determined by reverse-phase HPLC with absorbance set at $254 \mathrm{~nm}$. The product peaks were assigned by comparing the trace of the product mixture to those of control reactions using either acrylamide or glutathione alone. ${ }^{c} 1000 \mu \mathrm{M}$ of acrylamide and glutathione was used. Along with the desired cycloadduct, intramolecular adduct was also observed. 
Table S3, entry 1:

a) Reaction scheme

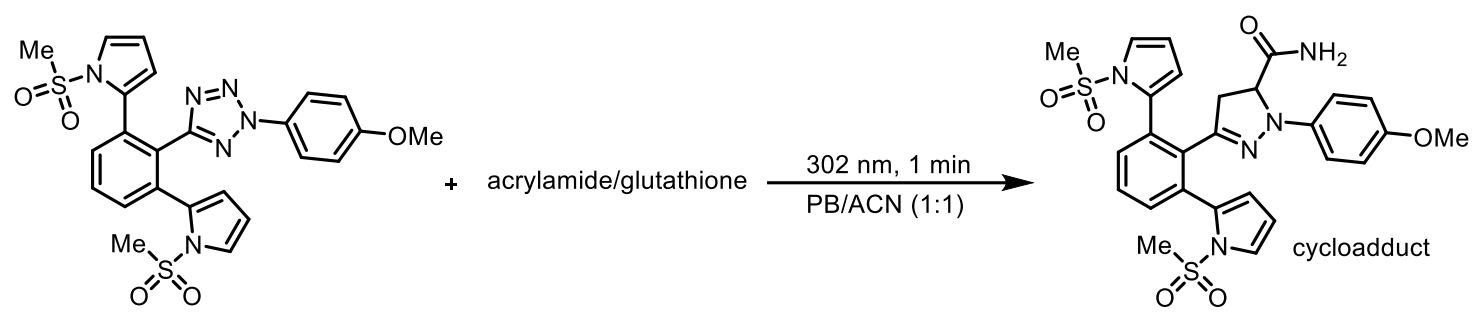

b) HPLC analysis
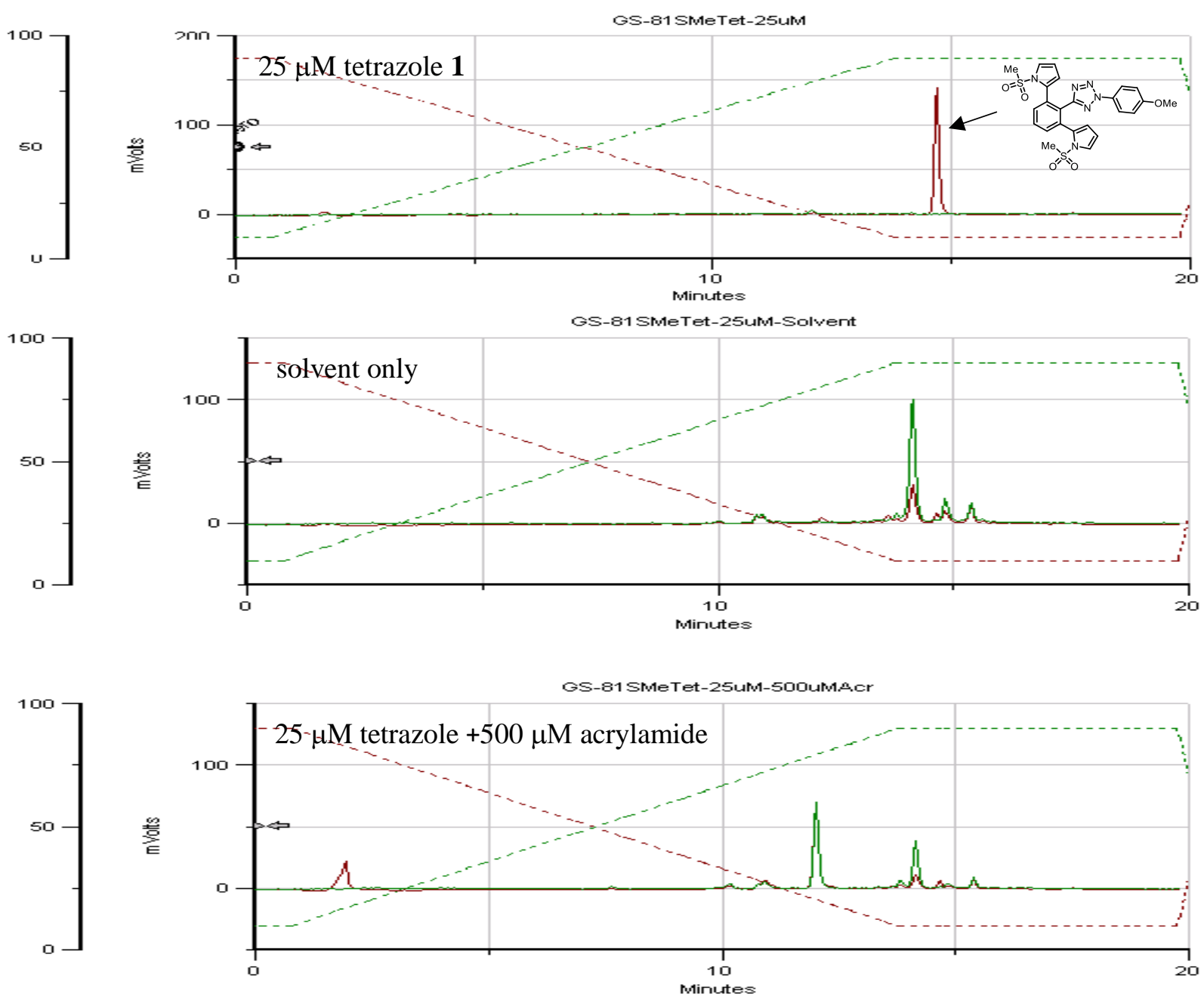

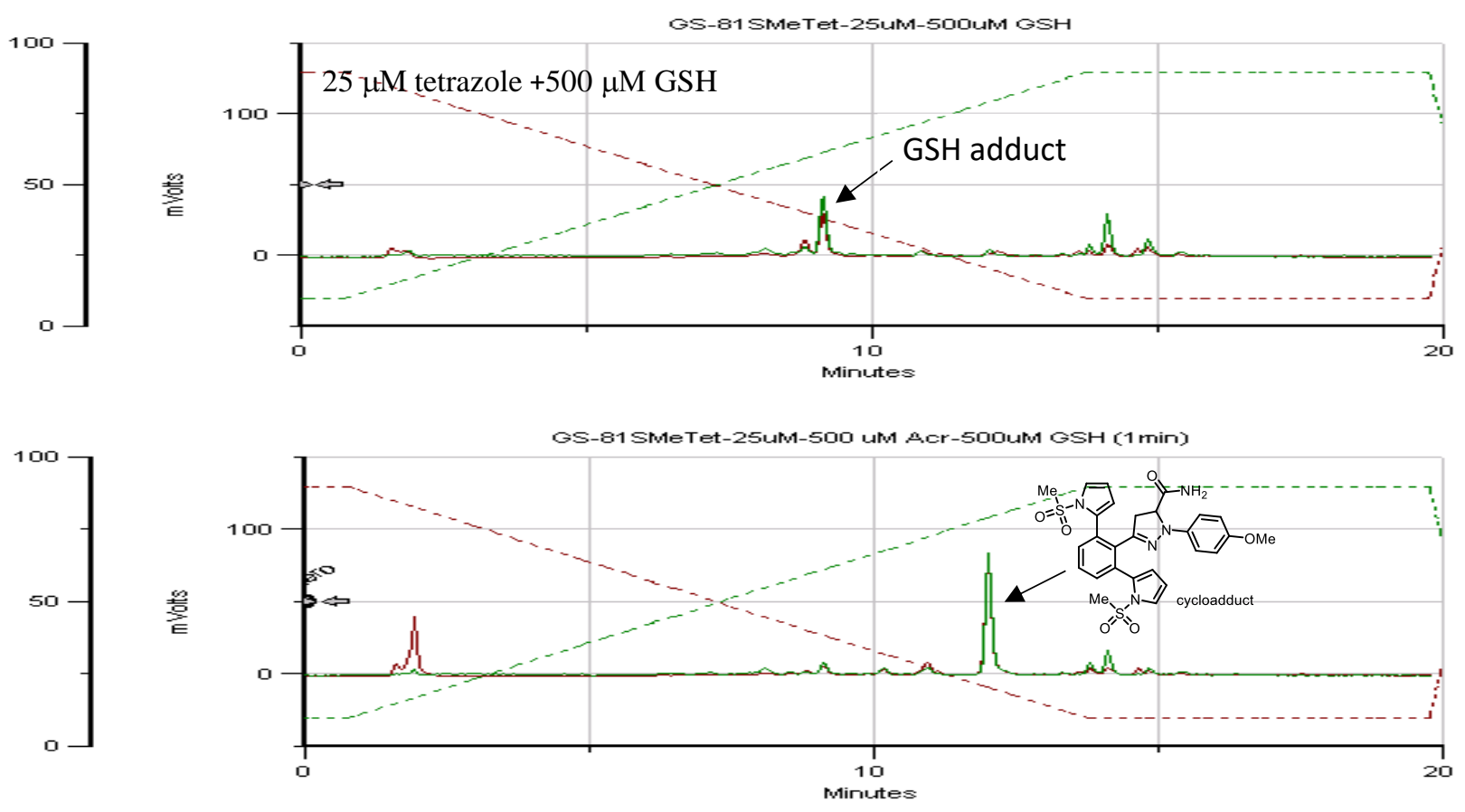

c) QTOF-LC/MS analysis of the reaction mixture

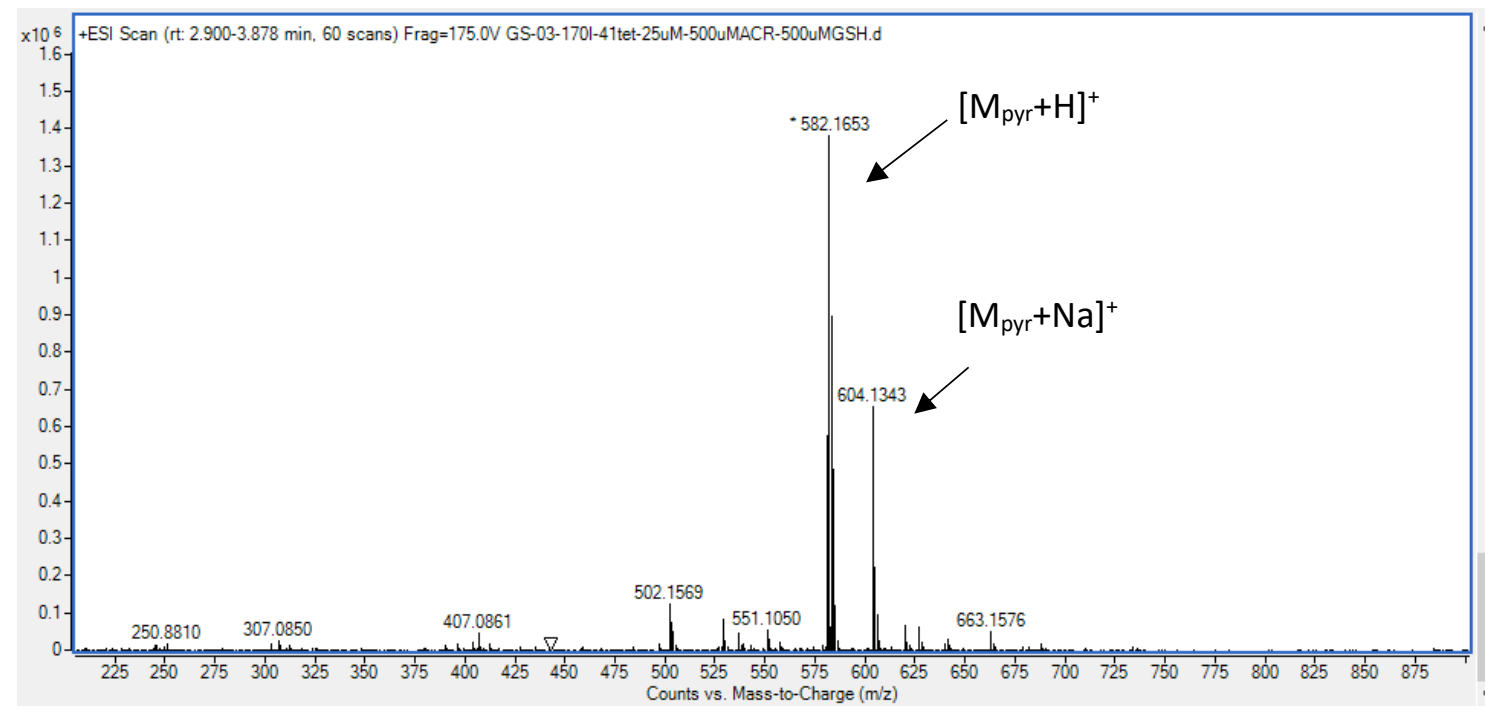


Table S3, entry 2:

a) Reaction scheme

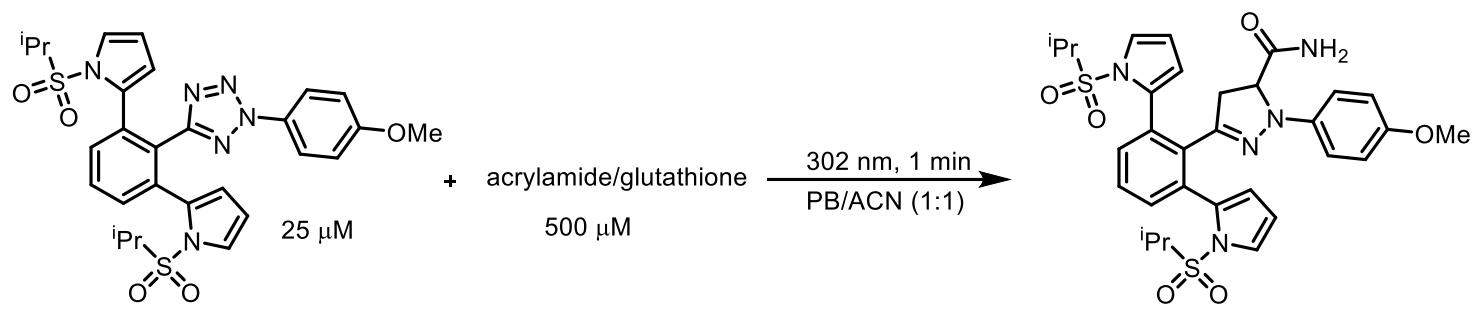

b) HPLC analysis of the reaction mixture

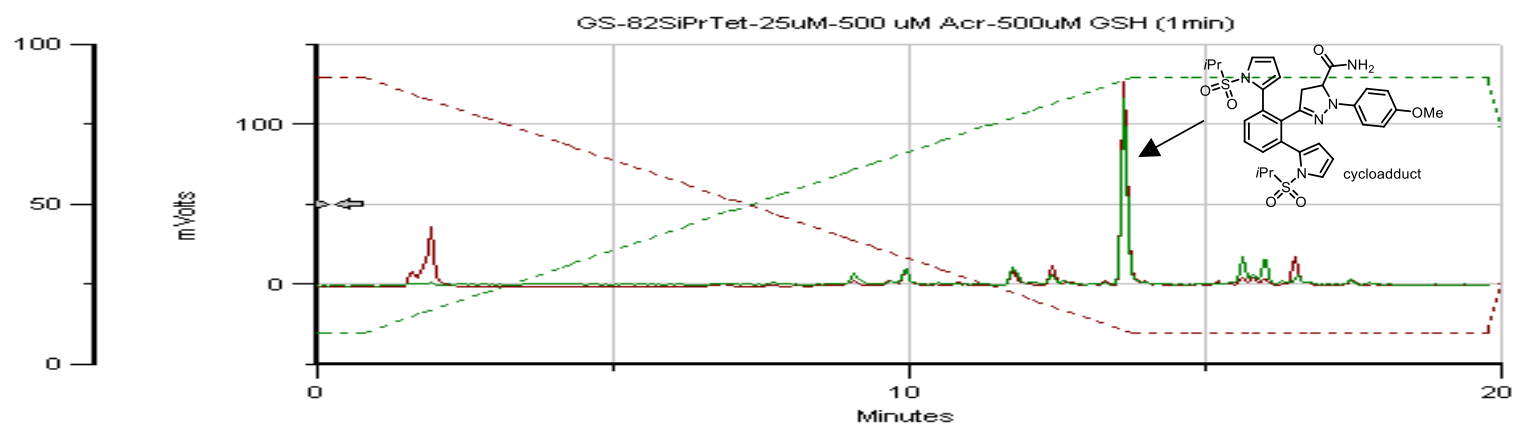

c) QTOF-LC/MS analysis of the reaction mixture

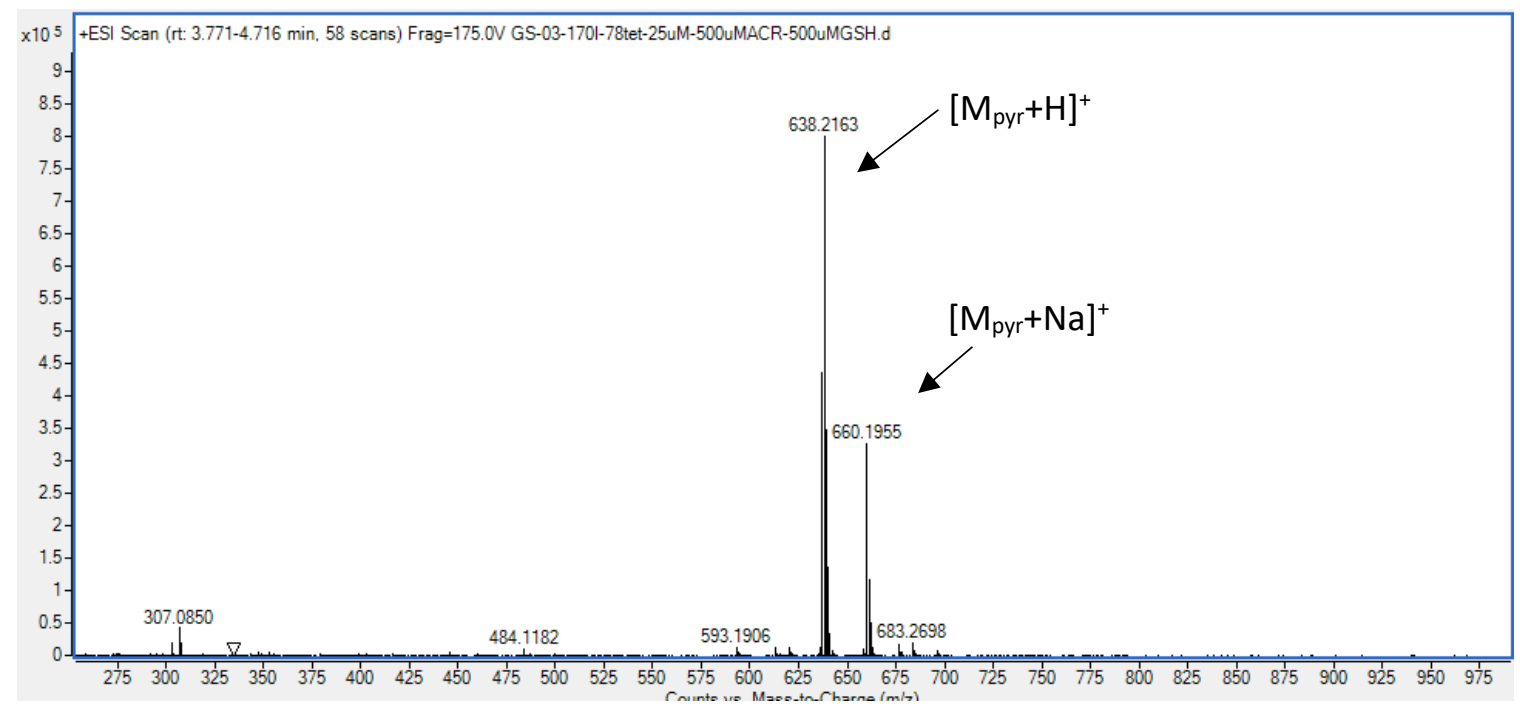


Table S3, entry 3:

a) Reaction scheme

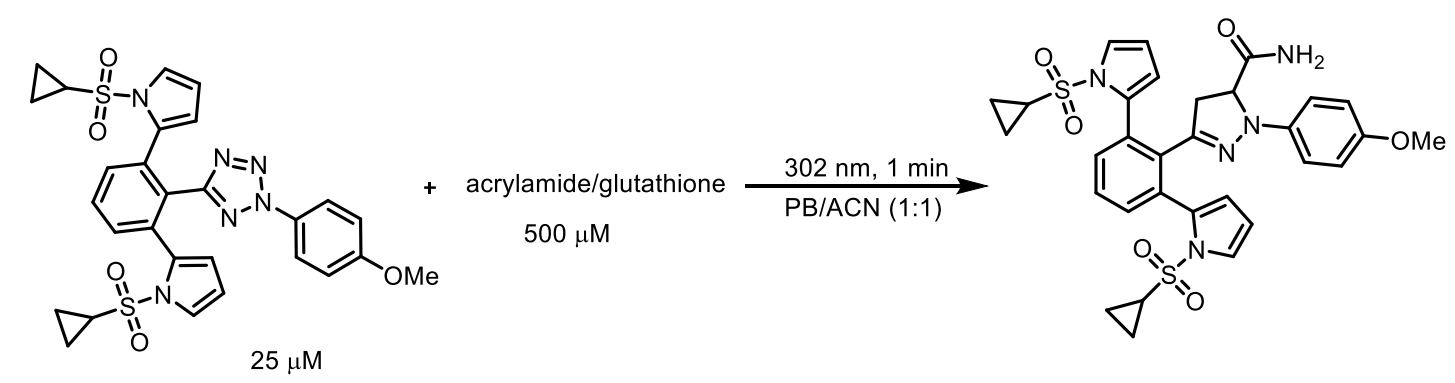

b) HPLC analysis of the reaction mixture

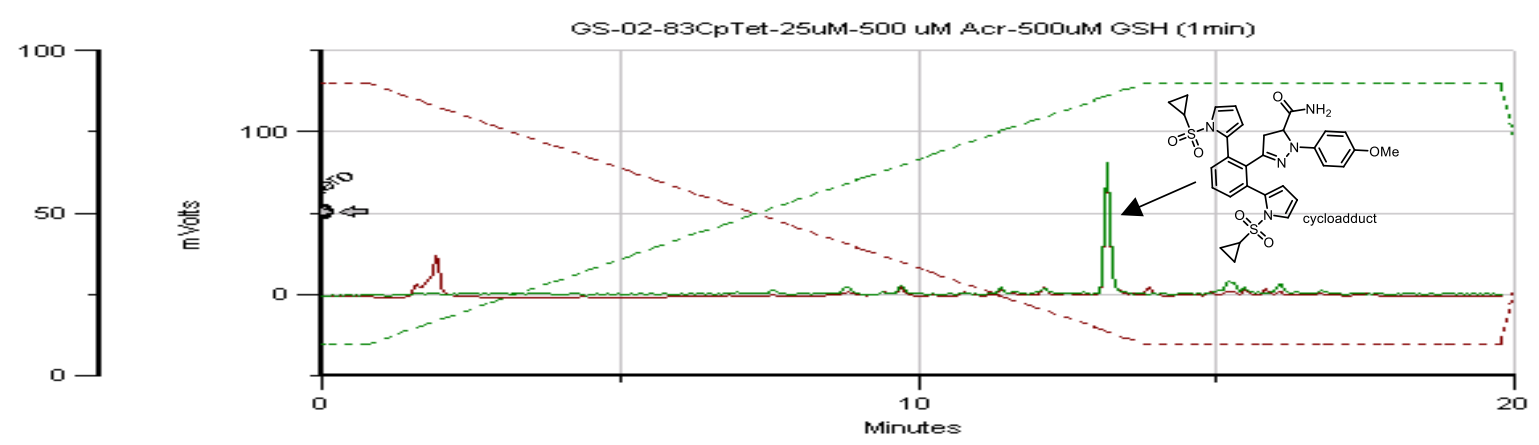

c) QTOF-LC/MS analysis of the reaction mixture

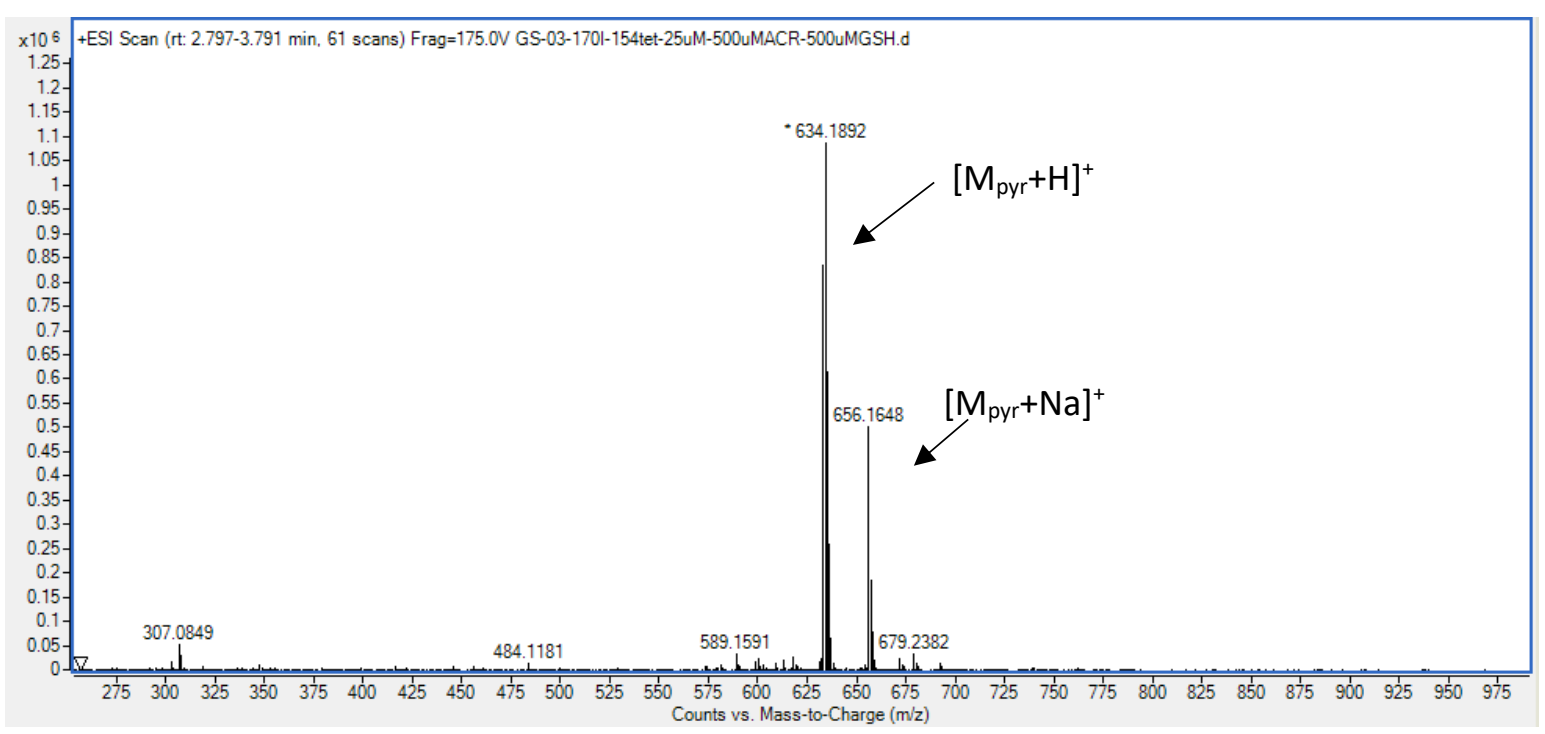


Table S3, entry 4:

a) Reaction scheme

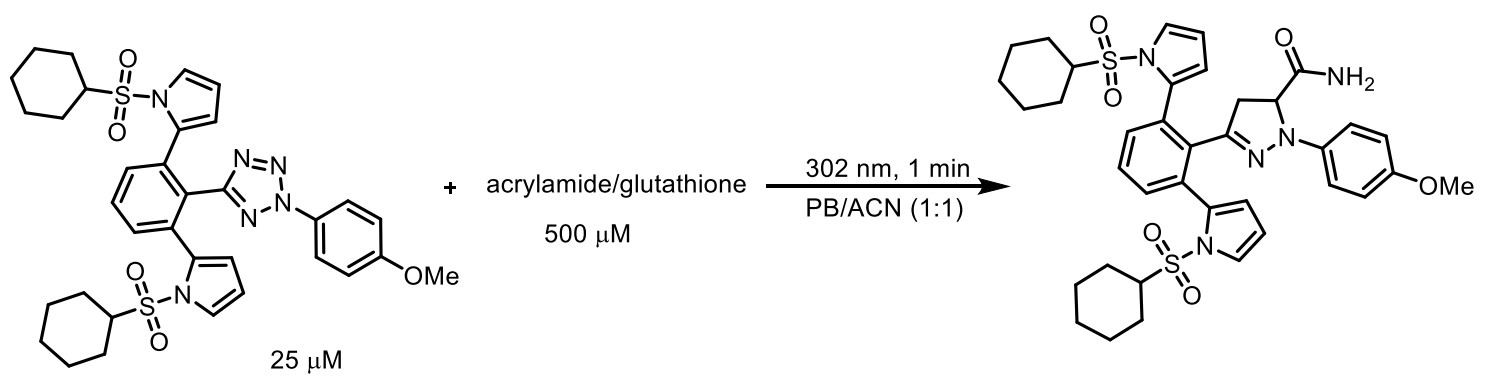

b) HPLC analysis of the reaction mixture

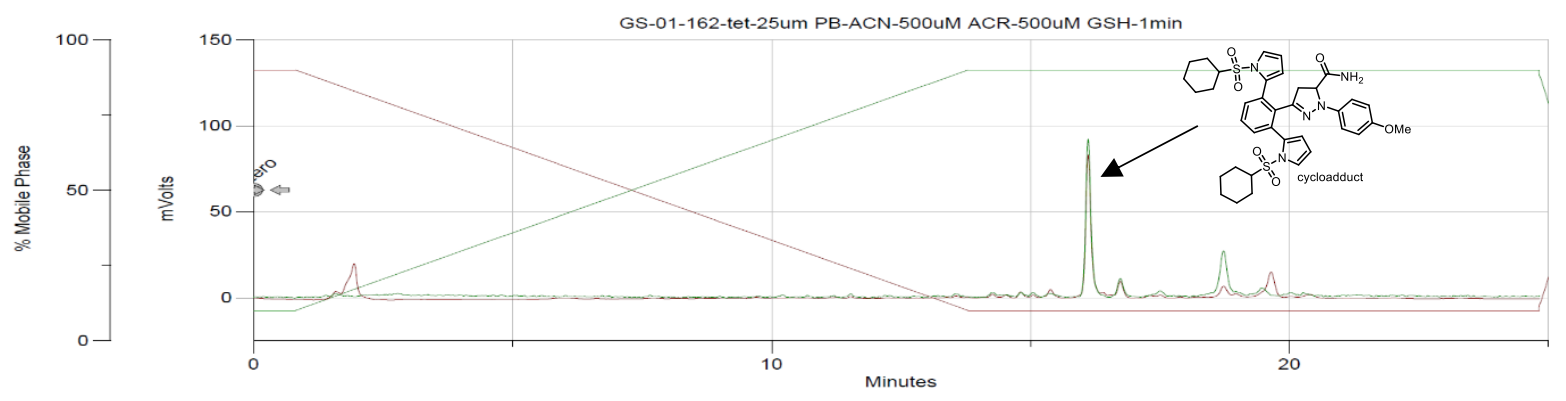

c) QTOF-LC/MS analysis of the reaction mixture

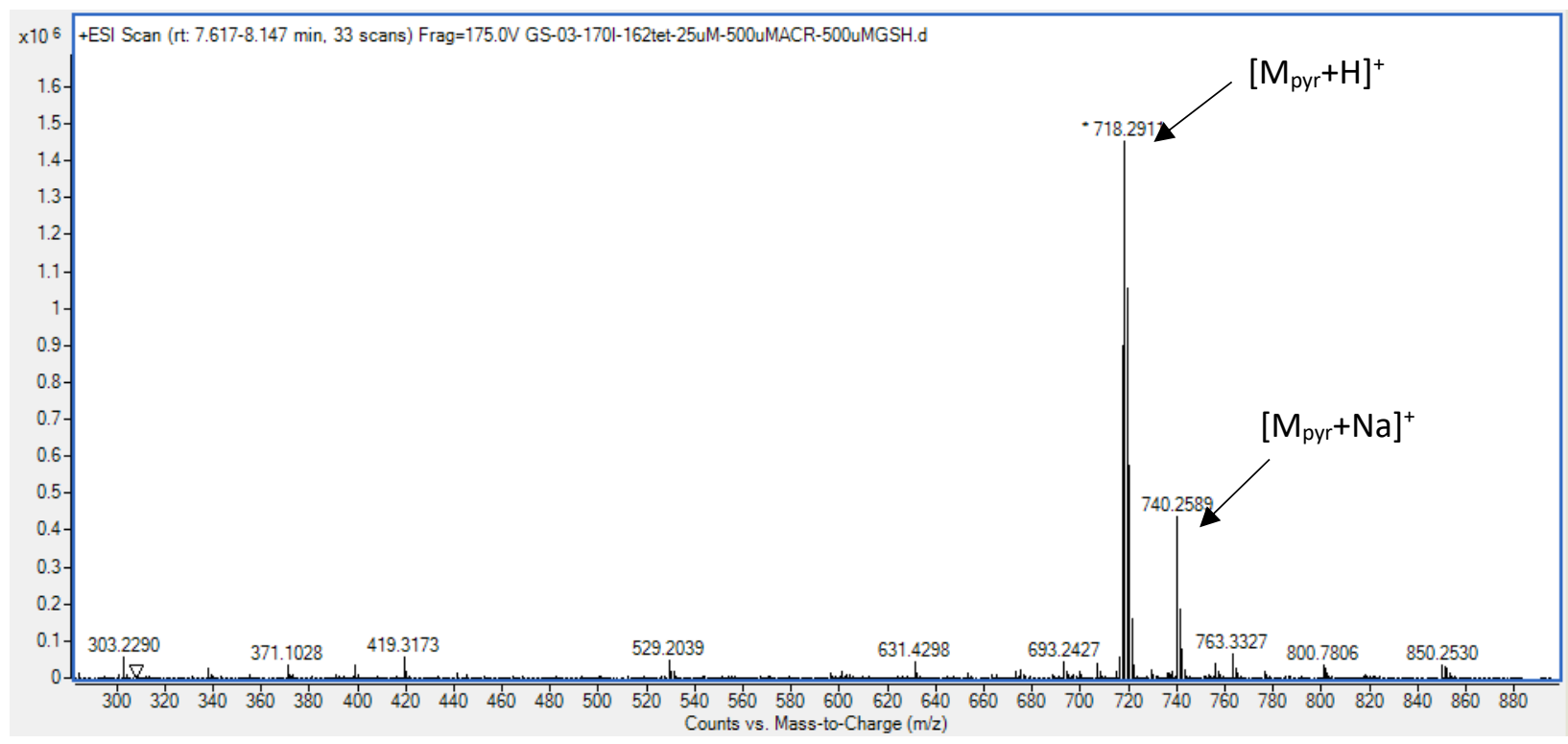


Table S3, entry 5:

a) Reaction scheme

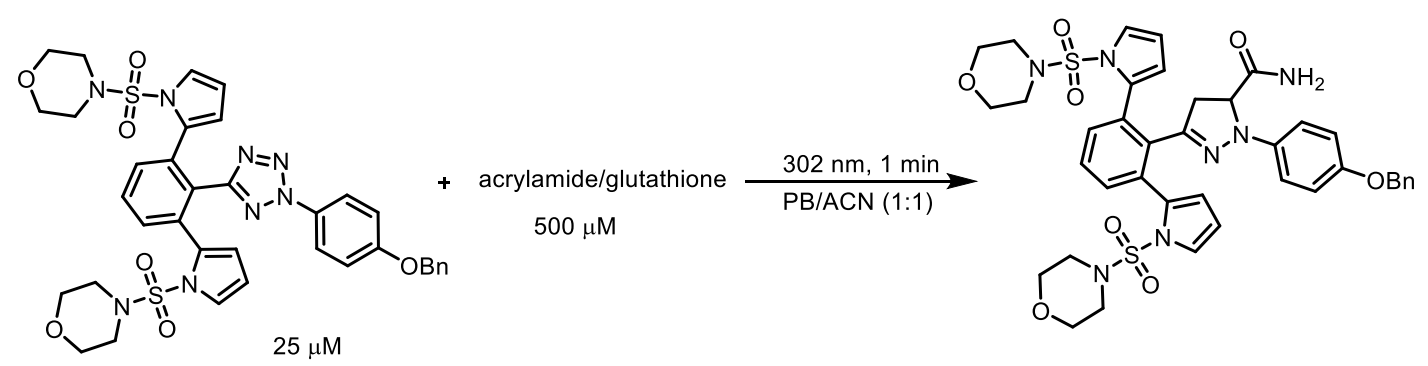

b) HPLC analysis of the reaction mixture

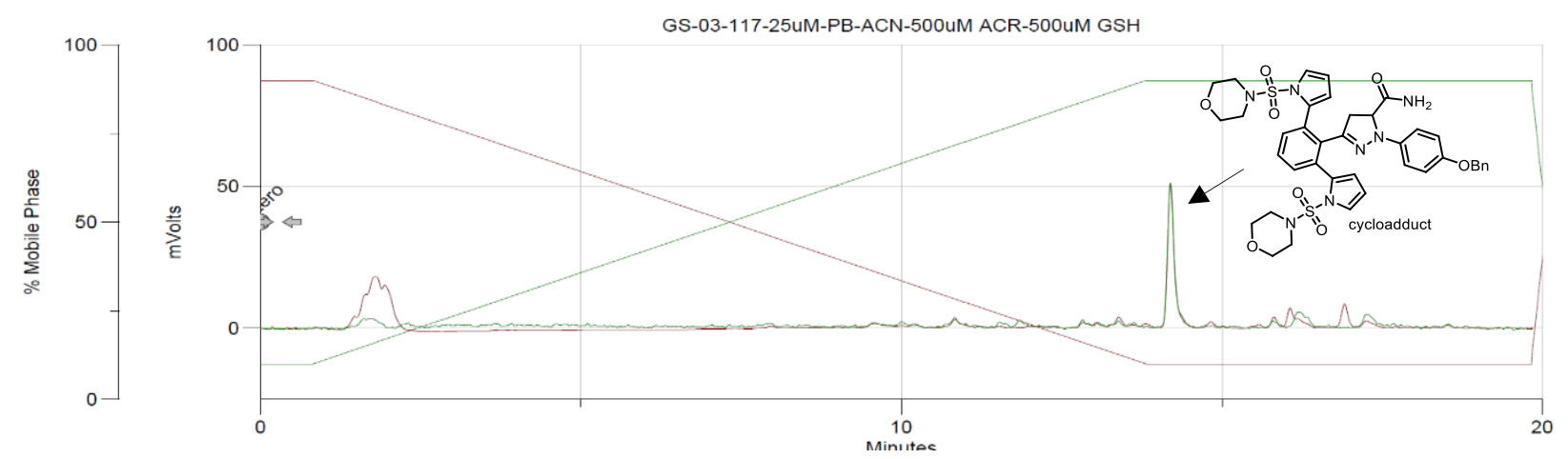

c) QTOF-LC/MS analysis of the reaction mixture

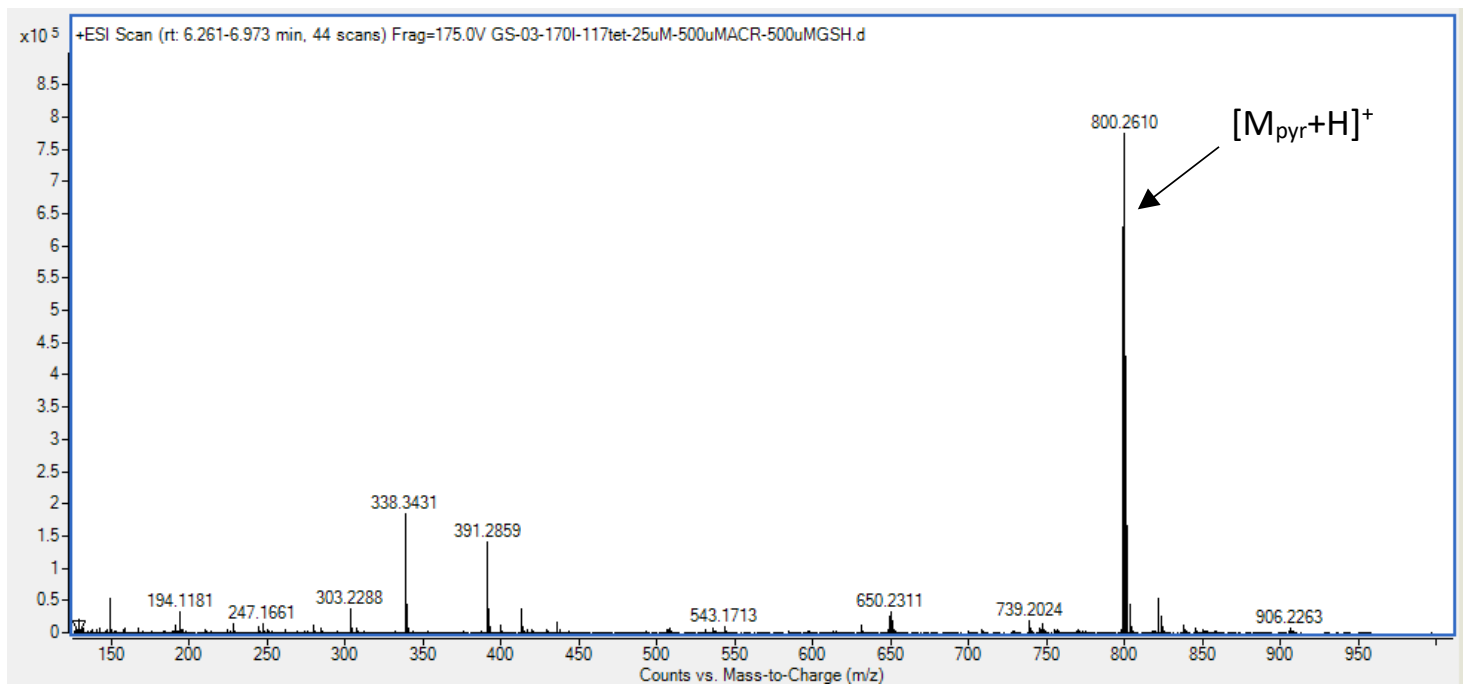


Table S3, entry 6:

a) Reaction scheme

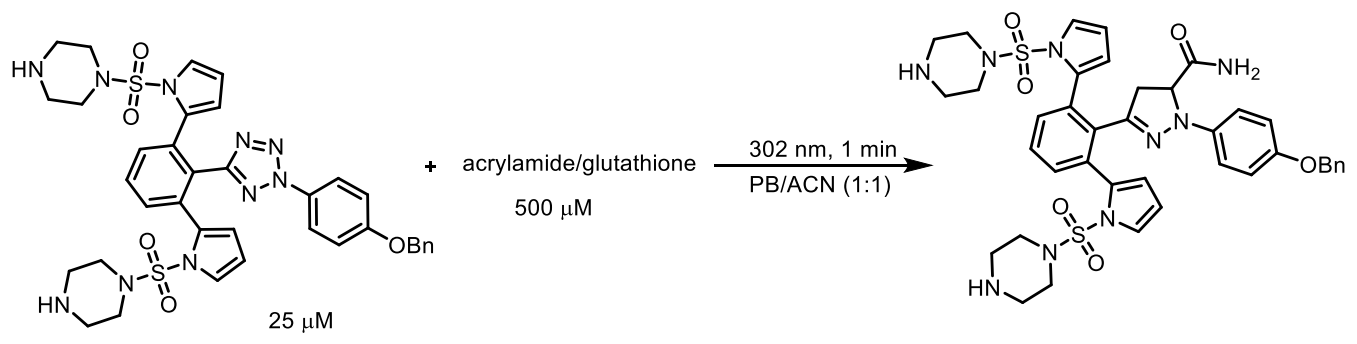

b) HPLC analysis of the reaction mixture

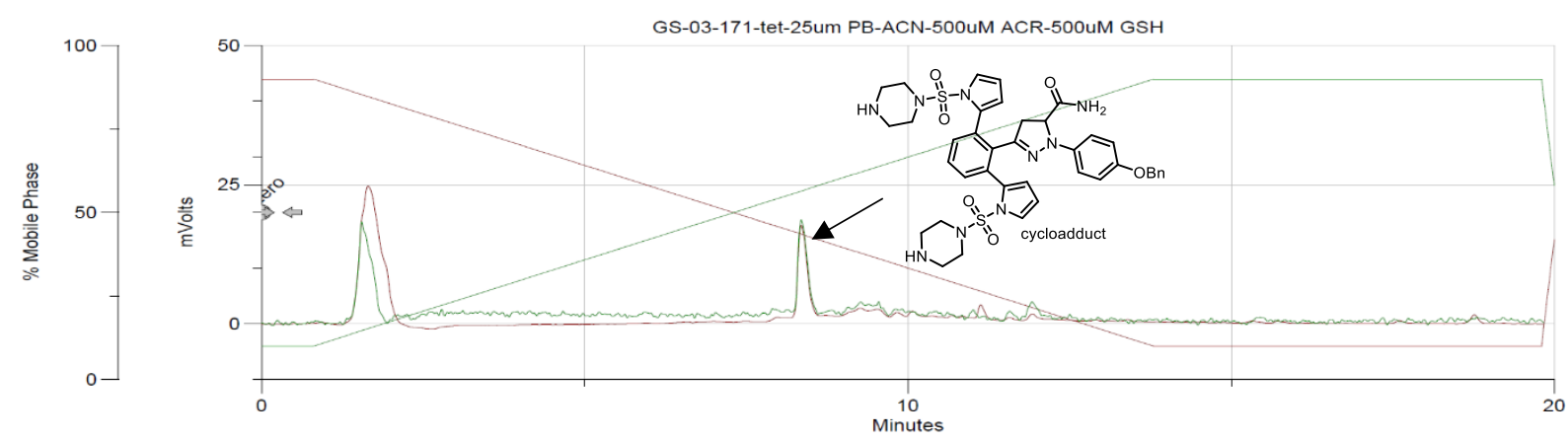

c) QTOF-LC/MS analysis of the reaction mixture

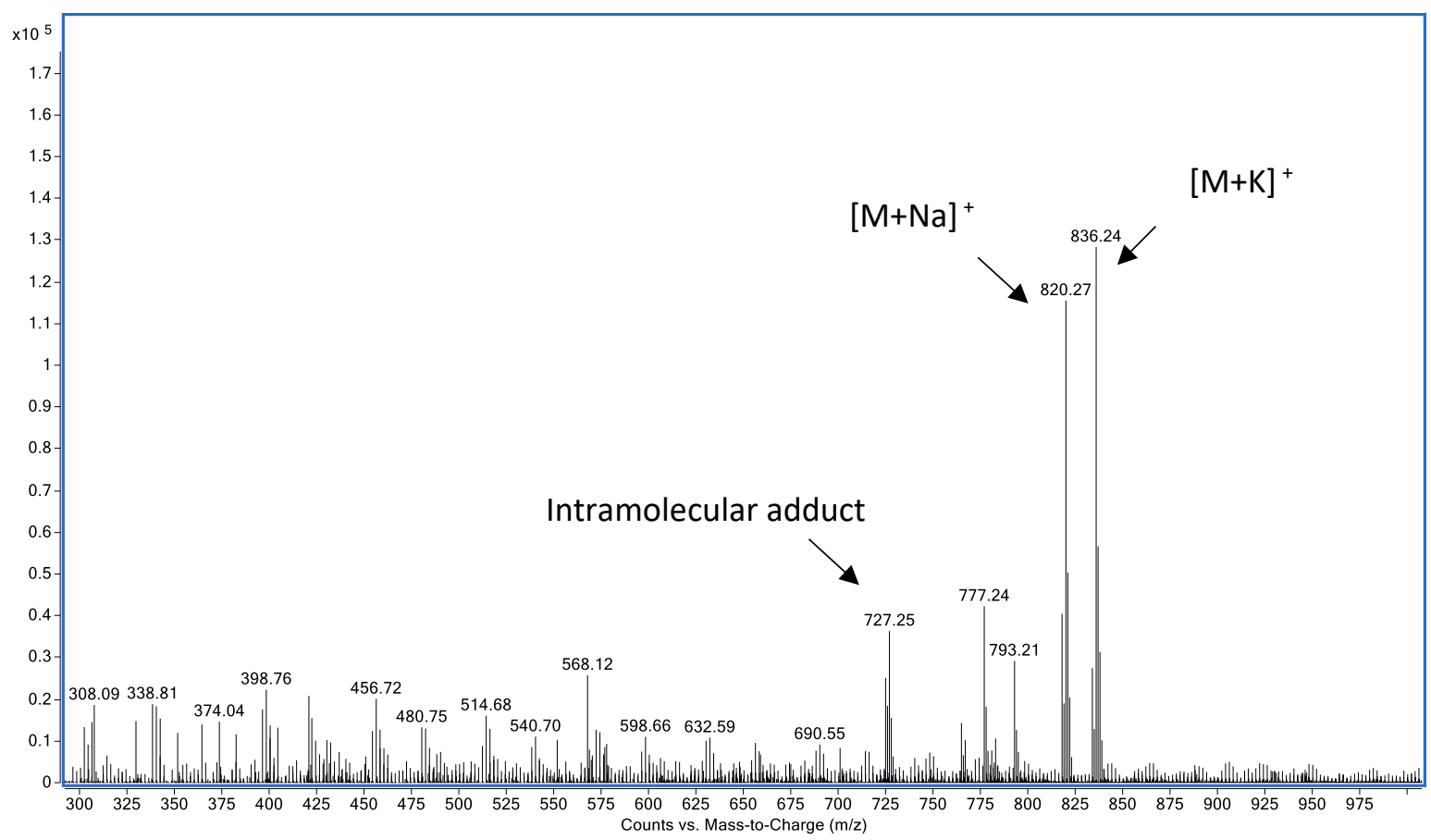


a)

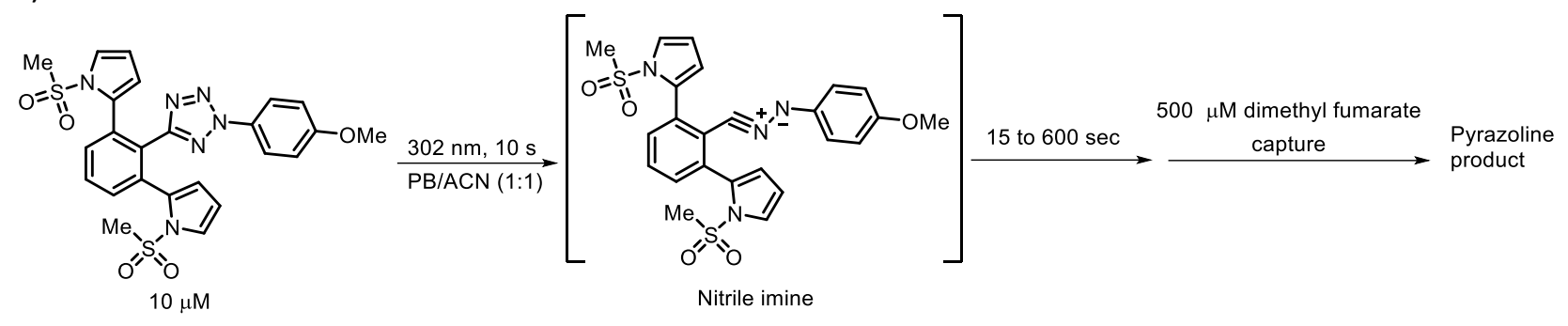

b)

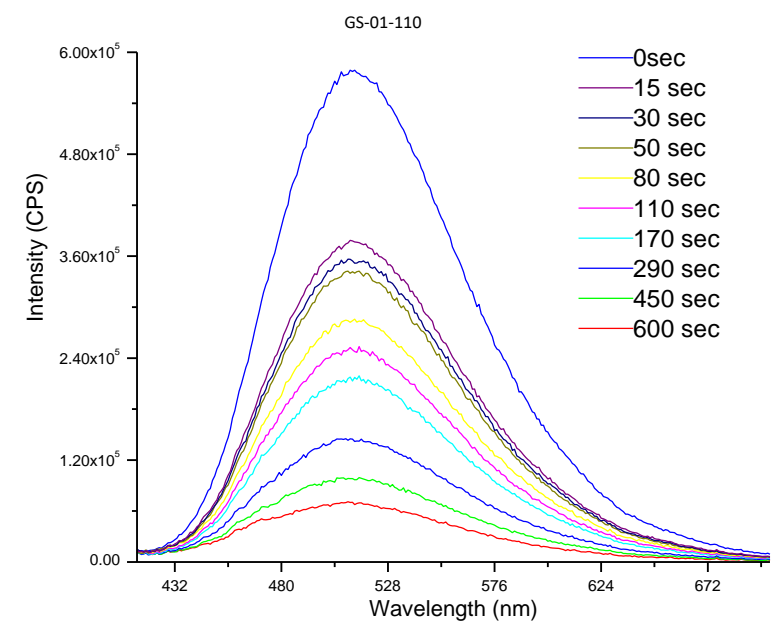

c)

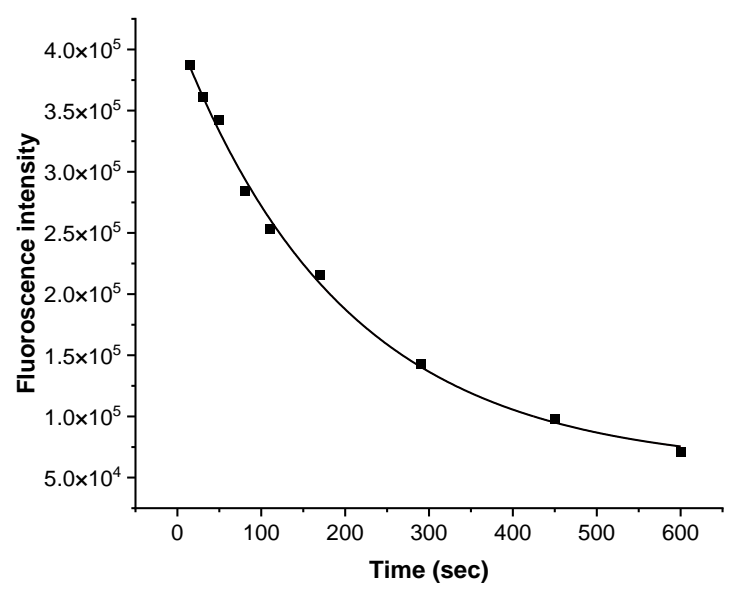

Figure S3. Determining half-life of the nitrile imine photogenerated from tetrazole 1. (a) Reaction scheme; (b) Fluorescence spectra of the pyrazoline product after reaction of dimethyl fumarate with the nitrile imine in solution at various time points. $\lambda_{\mathrm{ex}}=405 \mathrm{~nm}$; (c) Plot of fluorescence intensity vs. time. Based on the curve-fitting, the half-life of the nitrile imine was determined to be $138 \mathrm{sec}$. Each fluorescence measurement was repeated three times to obtain the mean values and standard deviations. 
a)

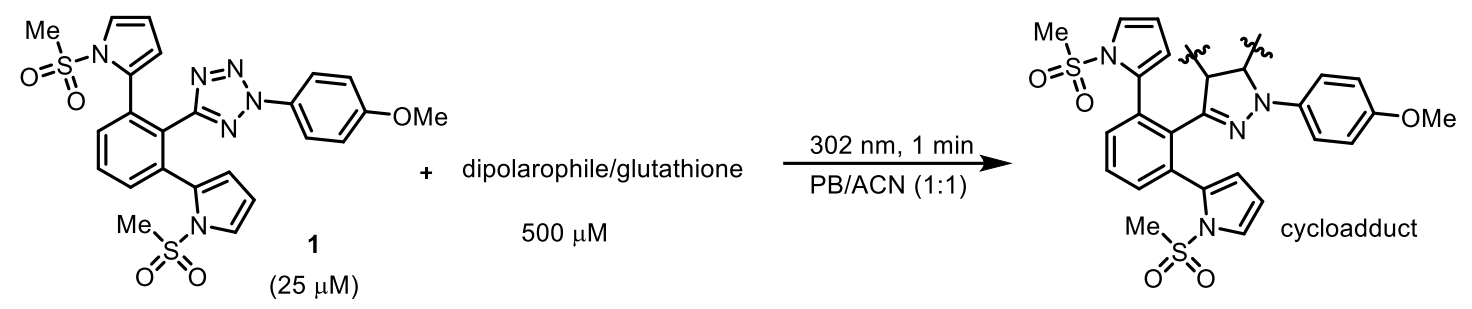

b)
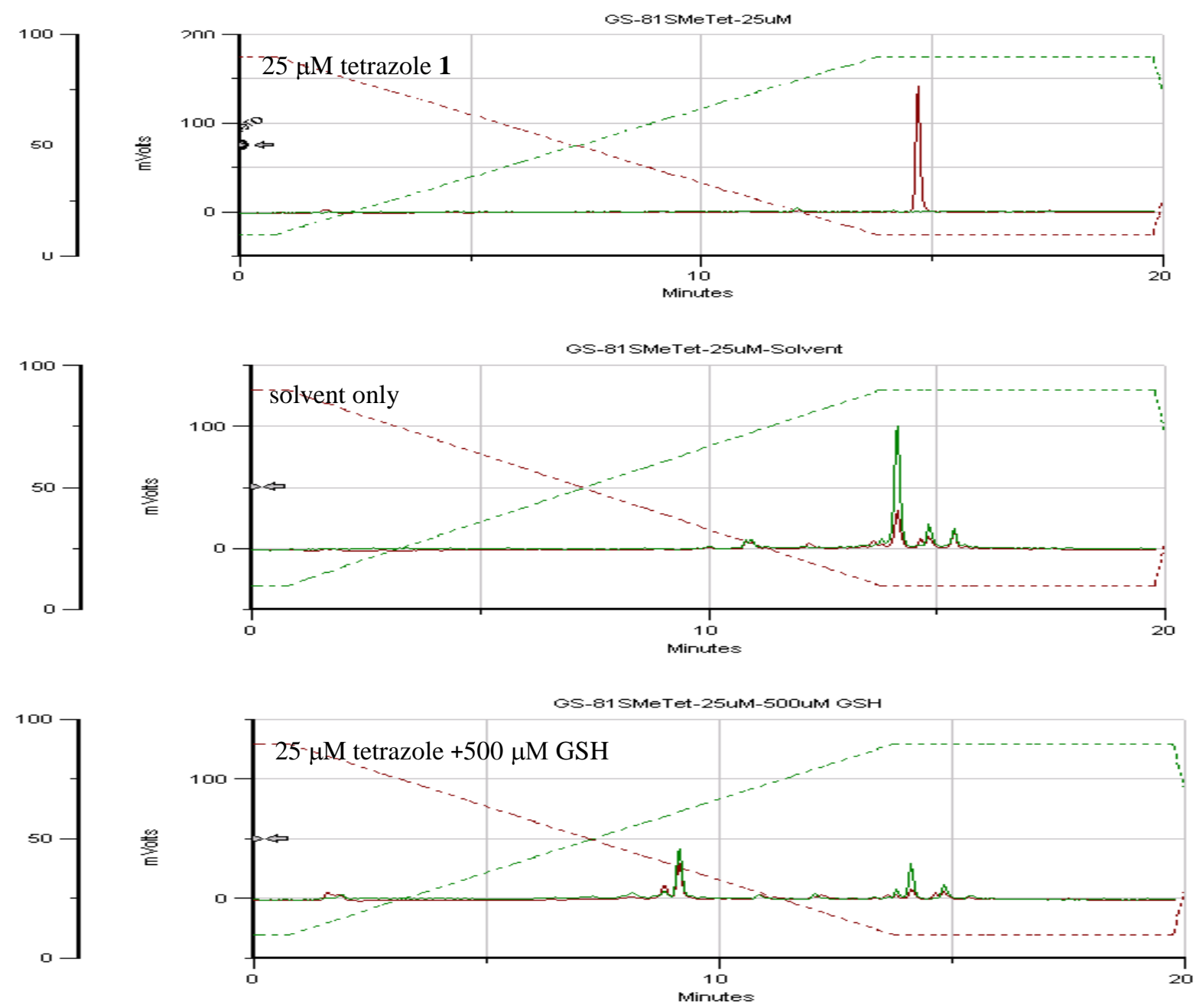

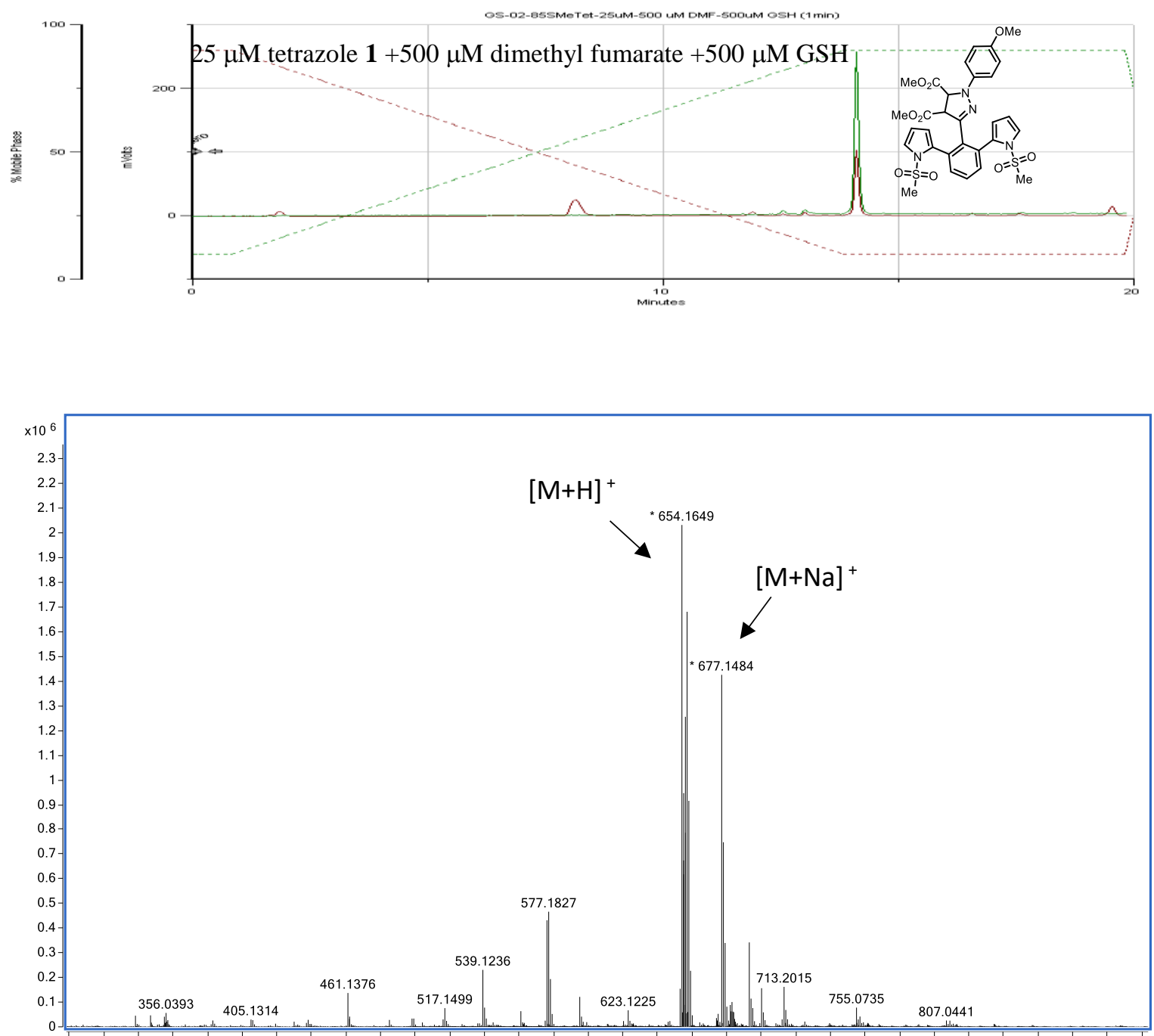

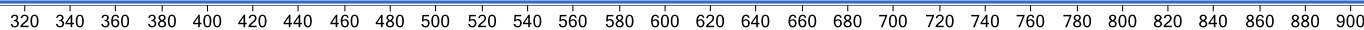
Counts vs. Mass-to-Charge $(\mathrm{m} / \mathrm{z})$ 

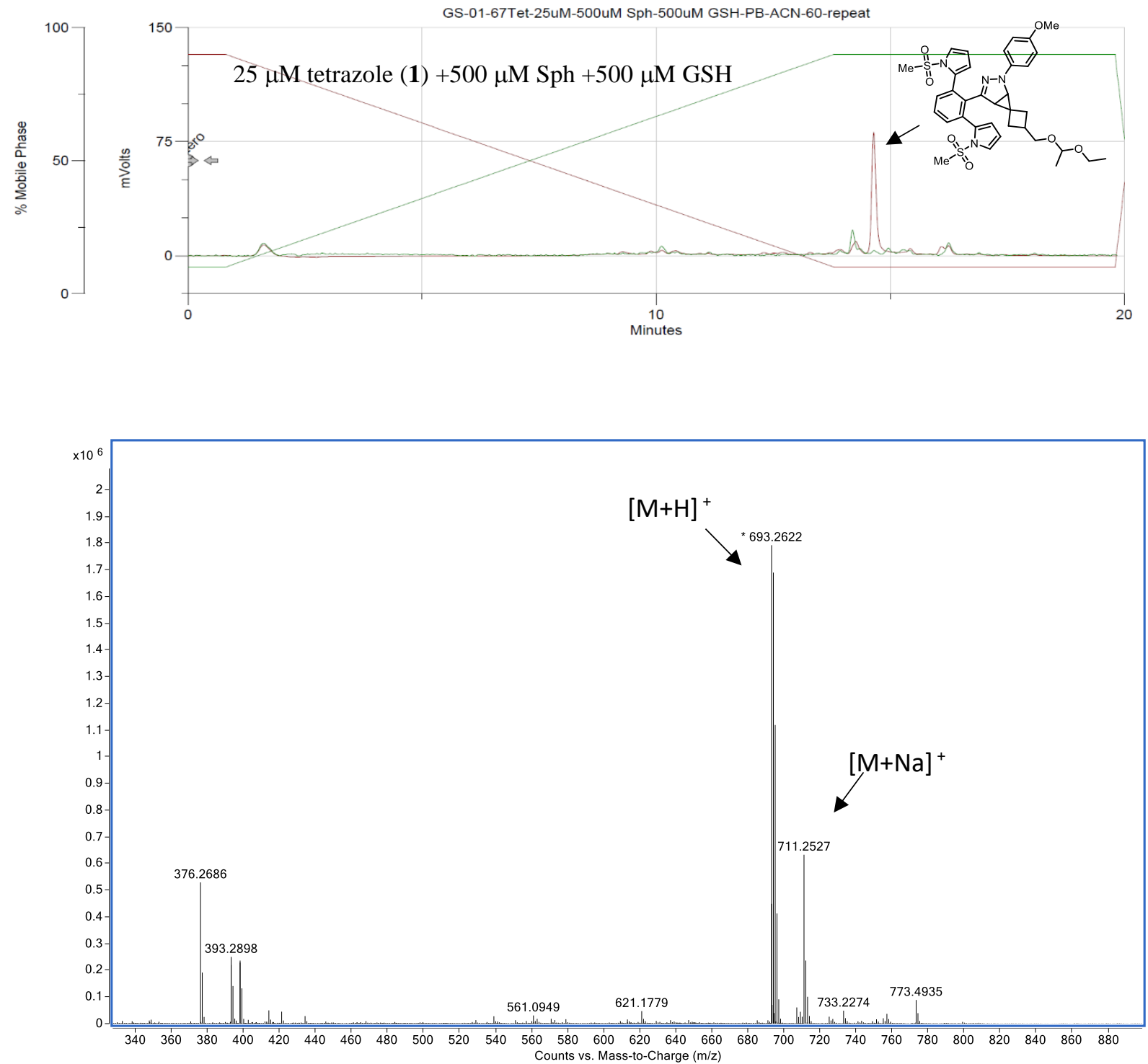

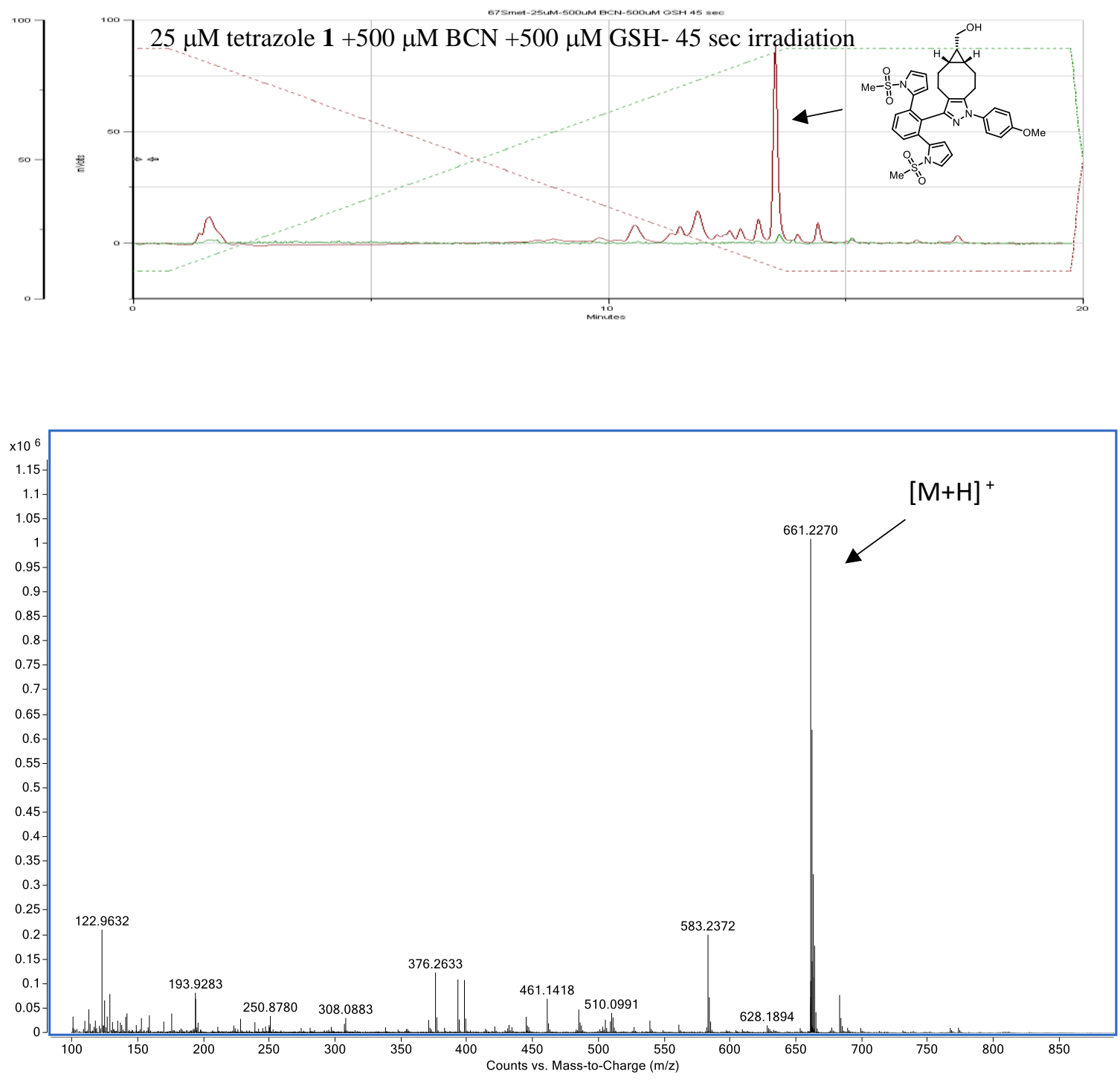

Figure S4. Survey of photoclick reactions of tetrazole 1 with various dipolarophiles. (a) Reaction scheme; (b) HPLC analysis of the reaction mixture. Red trace = absorbance at $254 \mathrm{~nm}$; green trace $=$ absorbance at $370 \mathrm{~nm}$. 
a)

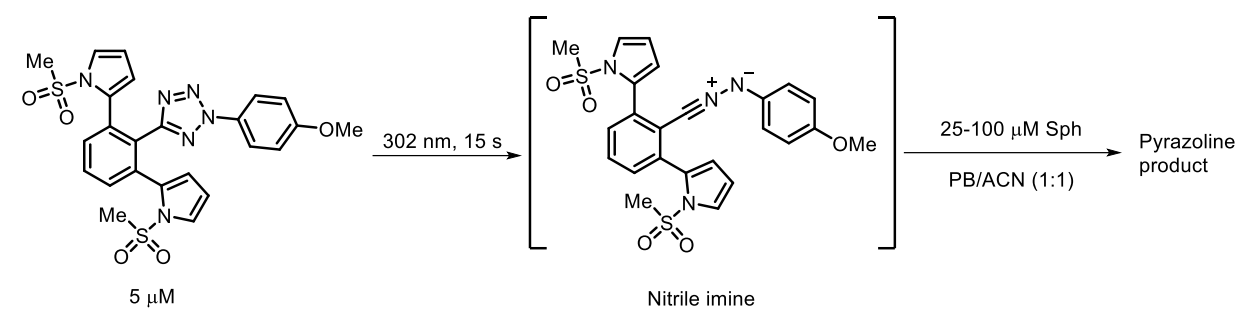

b)
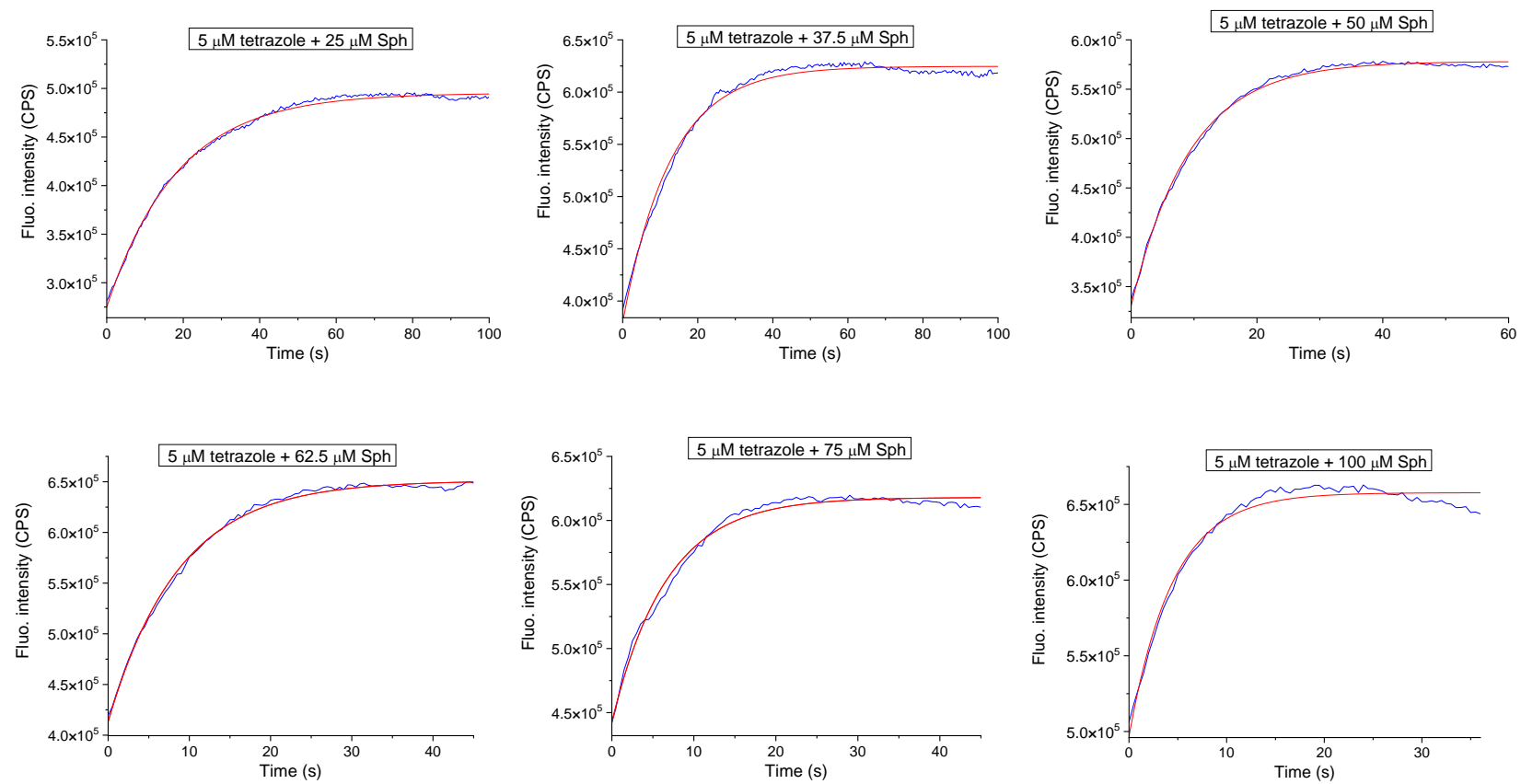

c)

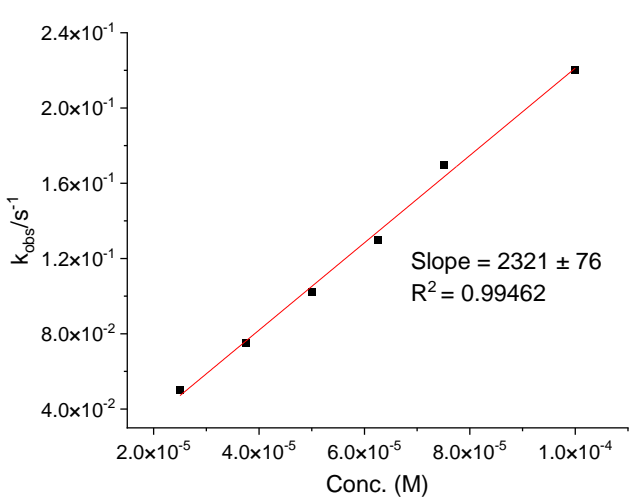

Figure S5. Kinetics measurement of the cycloaddition between tetrazole 1 and Sph. A 5- $\mu \mathrm{M}$ tetrazole solution in $500 \mu \mathrm{L} \mathrm{ACN}$ was irradiated at $302 \mathrm{~nm}$ for $15 \mathrm{sec}$ prior to addition to a solution of 25-100 $\mu \mathrm{M}$ Sph in $500 \mu \mathrm{L}$ phosphate buffer. (a) Reaction scheme. (b) Time-course of the reaction between tetrazole 1 and Sph. The pyrazoline product was monitored using fluorescence $\left(\lambda_{\text {ex }}=405 \mathrm{~nm}\right)$. Measurements were repeated three times. The pyrazoline product formation was fitted to an exponential rise to maximum equation, $\mathrm{y}=\left(\mathrm{y}_{0}-\mathrm{a}\right) \mathrm{e}^{\text {kobs } t}+\mathrm{a}$, to give $k_{\text {obs. }}$ (c) Plot of $k_{\mathrm{obs}} \mathrm{vs.} \mathrm{Sph}$ concentration. The second-order rate constant, $k_{2}$, was determined to be $2321 \pm 76$ based on the slope of the fitted curve. 
a)

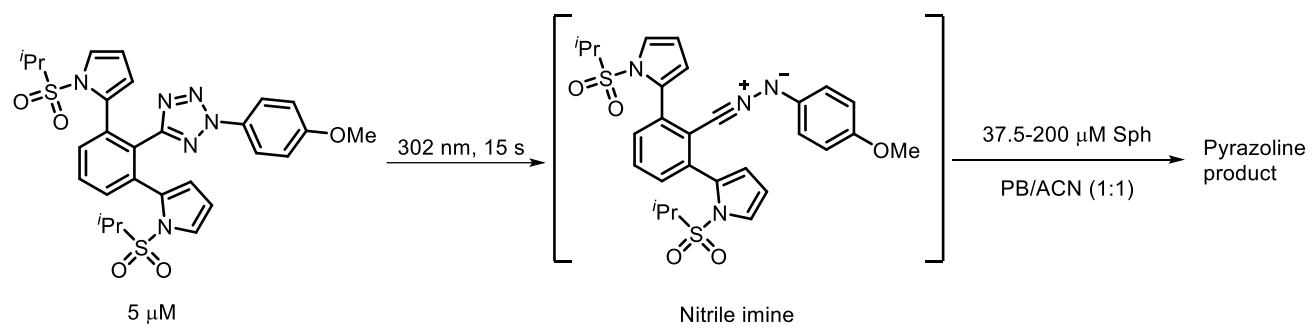

b)
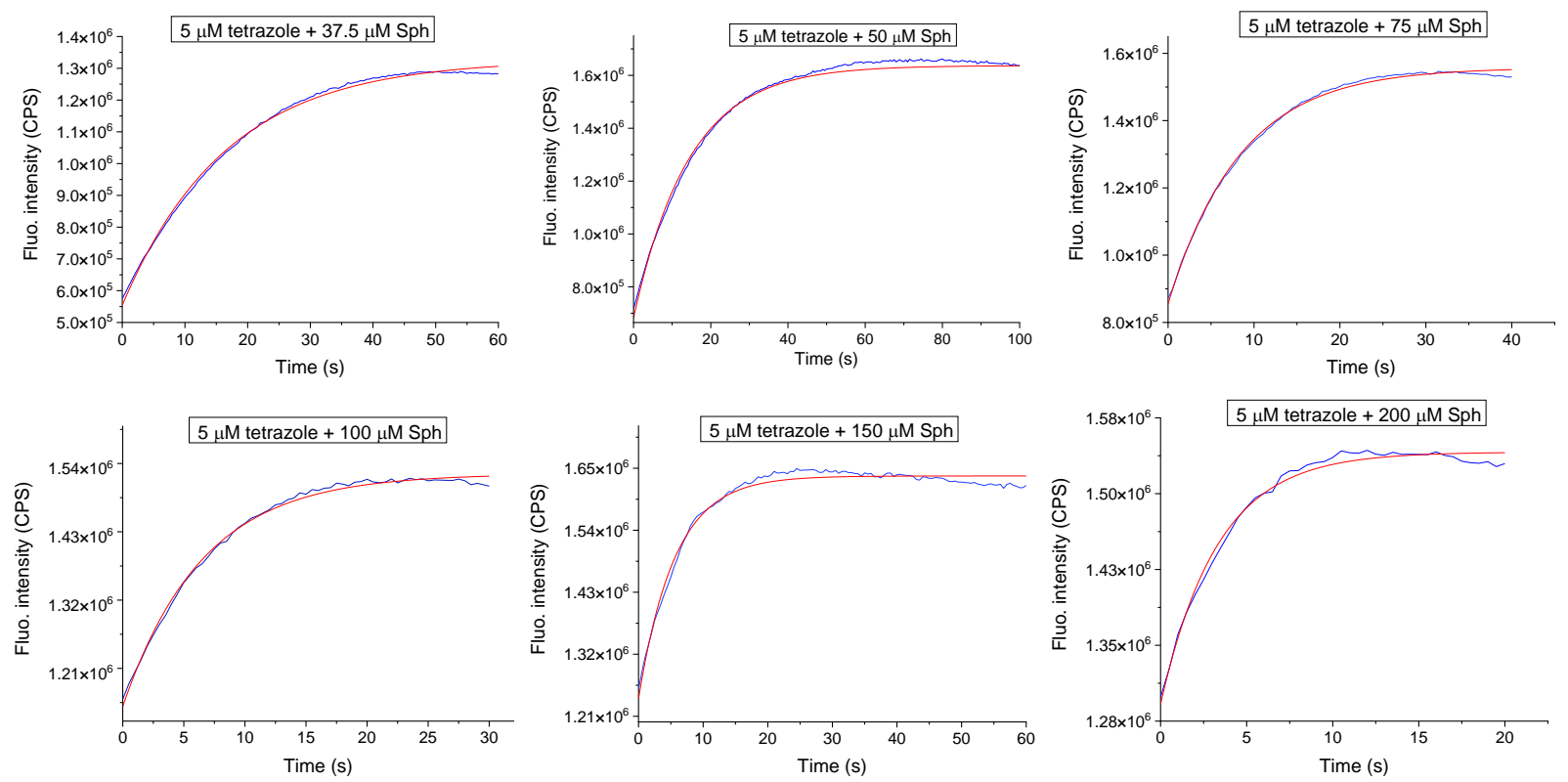

c)

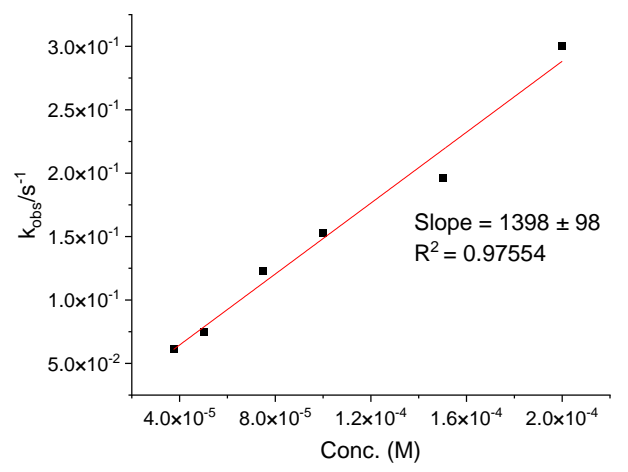

Figure S6. Kinetics measurement of the cycloaddition between tetrazole 2 and Sph. A $5-\mu \mathrm{M}$ tetrazole solution in $500 \mu \mathrm{L} \mathrm{ACN}$ was irradiated at $302 \mathrm{~nm}$ for $15 \mathrm{sec}$ prior to addition to a solution of 37.5-200 $\mu \mathrm{M}$ Sph in $500 \mu \mathrm{L}$ phosphate buffer. (a) Reaction scheme. (b) Time-course of the reaction between tetrazole 2 and Sph. The pyrazoline product was monitored using fluorescence $\left(\lambda_{\mathrm{ex}}=405 \mathrm{~nm}\right)$. Measurements were repeated three times. The pyrazoline product formation was fitted to an exponential rise to maximum equation, $\mathrm{y}=\left(\mathrm{y}_{0}-\mathrm{a}\right) \mathrm{e}^{\mathrm{kobs} t}+\mathrm{a}$, to give $k_{\mathrm{obs}}$. (c) Plot of $k_{\mathrm{obs}} v$ s. Sph concentration. The second-order rate constant, $k_{2}$, was determined to be $1398 \pm 98$ based on the slope of the fitted curve. 
a)

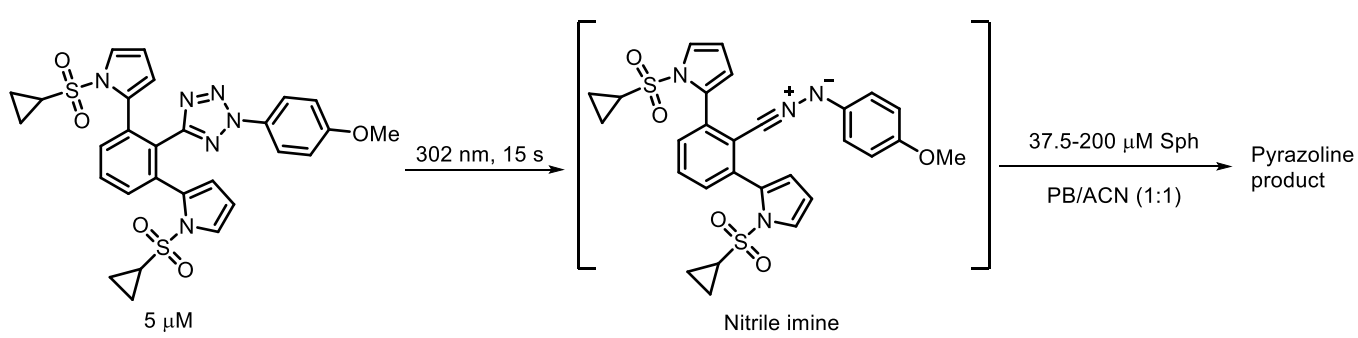

b)
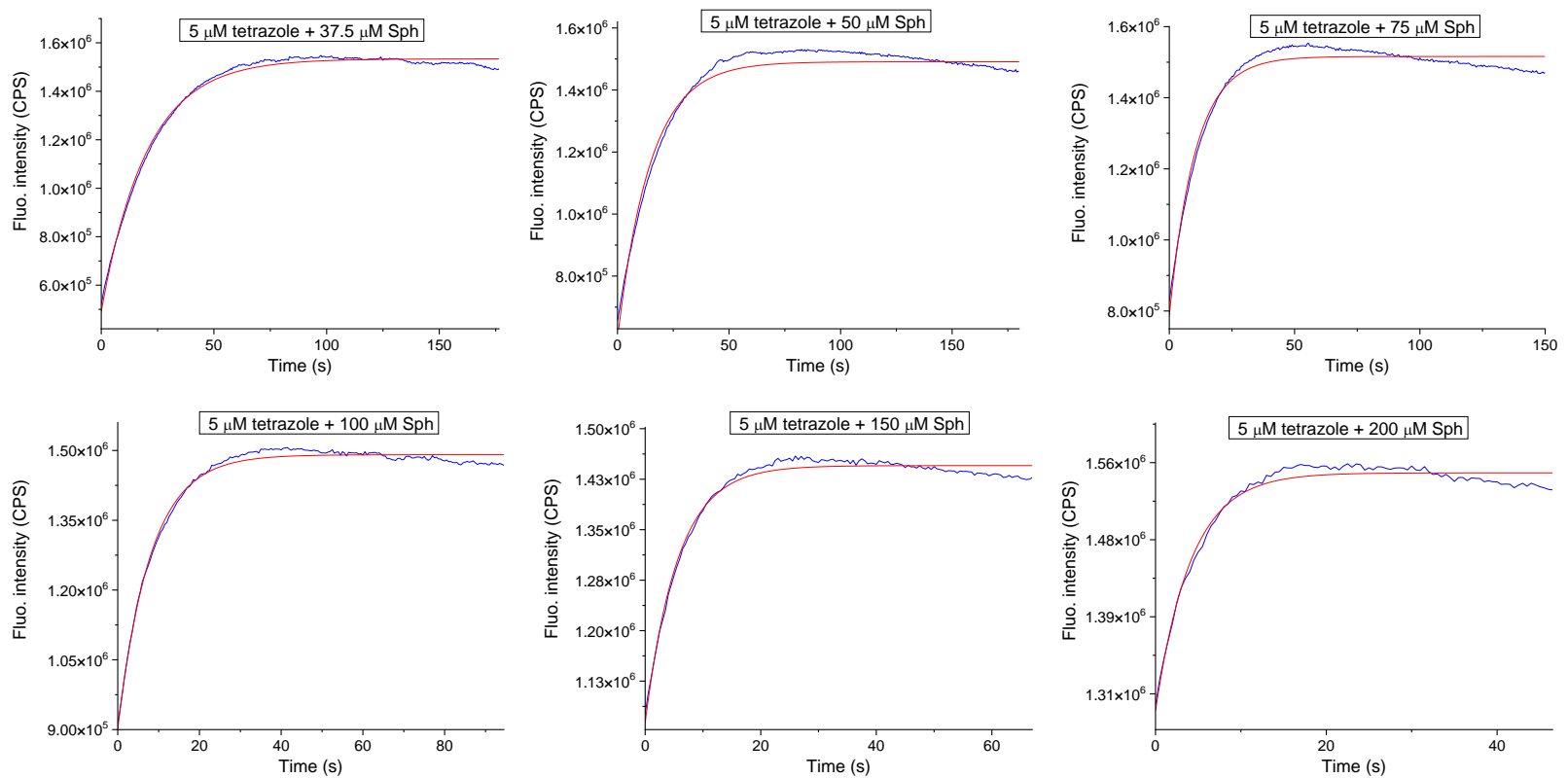

c)

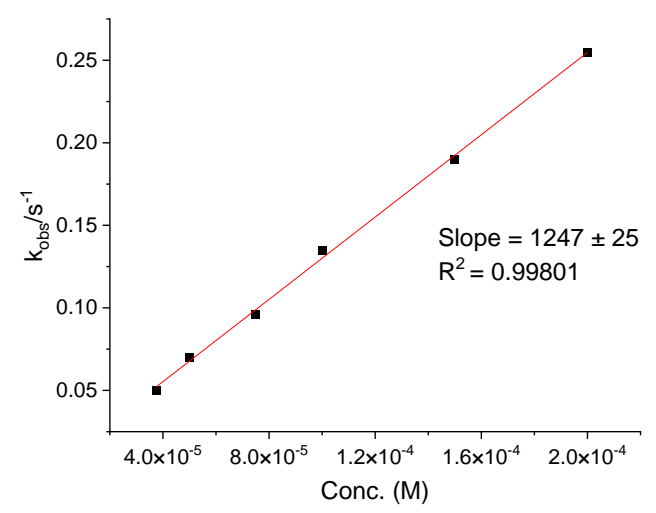

Figure S7. Kinetics measurement of the cycloaddition between tetrazole 3 and Sph. A 5- $\mu \mathrm{M}$ tetrazole solution in $500 \mu \mathrm{L}$ ACN was irradiated at $302 \mathrm{~nm}$ for $15 \mathrm{sec}$ prior to addition to a solution of 37.5-200 $\mu \mathrm{M}$ Sph in $500 \mu \mathrm{L}$ phosphate buffer. (a) Reaction scheme. (b) Time-course of the reaction between tetrazole 3 and Sph. The pyrazoline product was monitored using fluorescence $\left(\lambda_{\mathrm{ex}}=405 \mathrm{~nm}\right)$. Measurements were repeated three times. The pyrazoline product formation was fitted to an exponential rise to maximum equation, $\mathrm{y}=\left(\mathrm{y}_{0}-\mathrm{a}\right) \mathrm{e}^{\text {kobs } t}+\mathrm{a}$, to give $k_{\mathrm{obs}}$. (c) Plot of $k_{\mathrm{obs}} \mathrm{vs.} \mathrm{Sph}$ concentration. The second-order rate constant, $k_{2}$, was determined to be $1247 \pm 25$ based on the slope of the fitted curve. 
a)
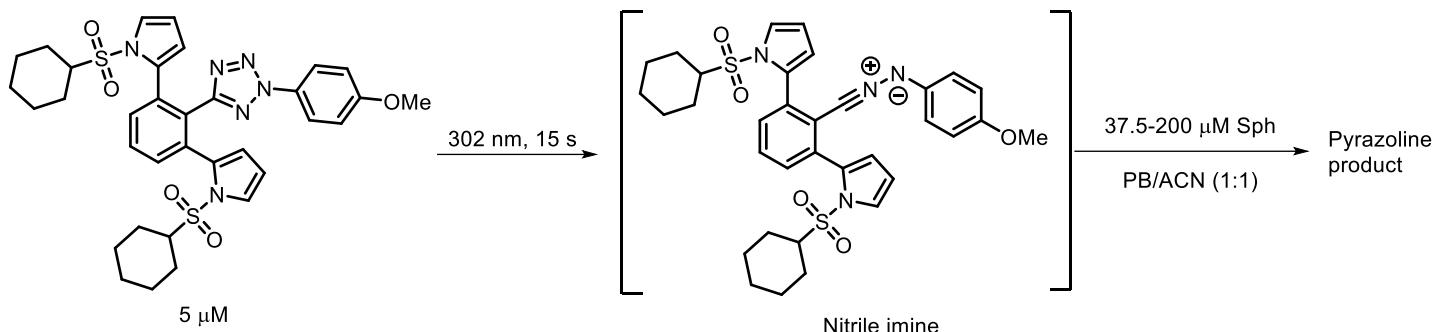

b)
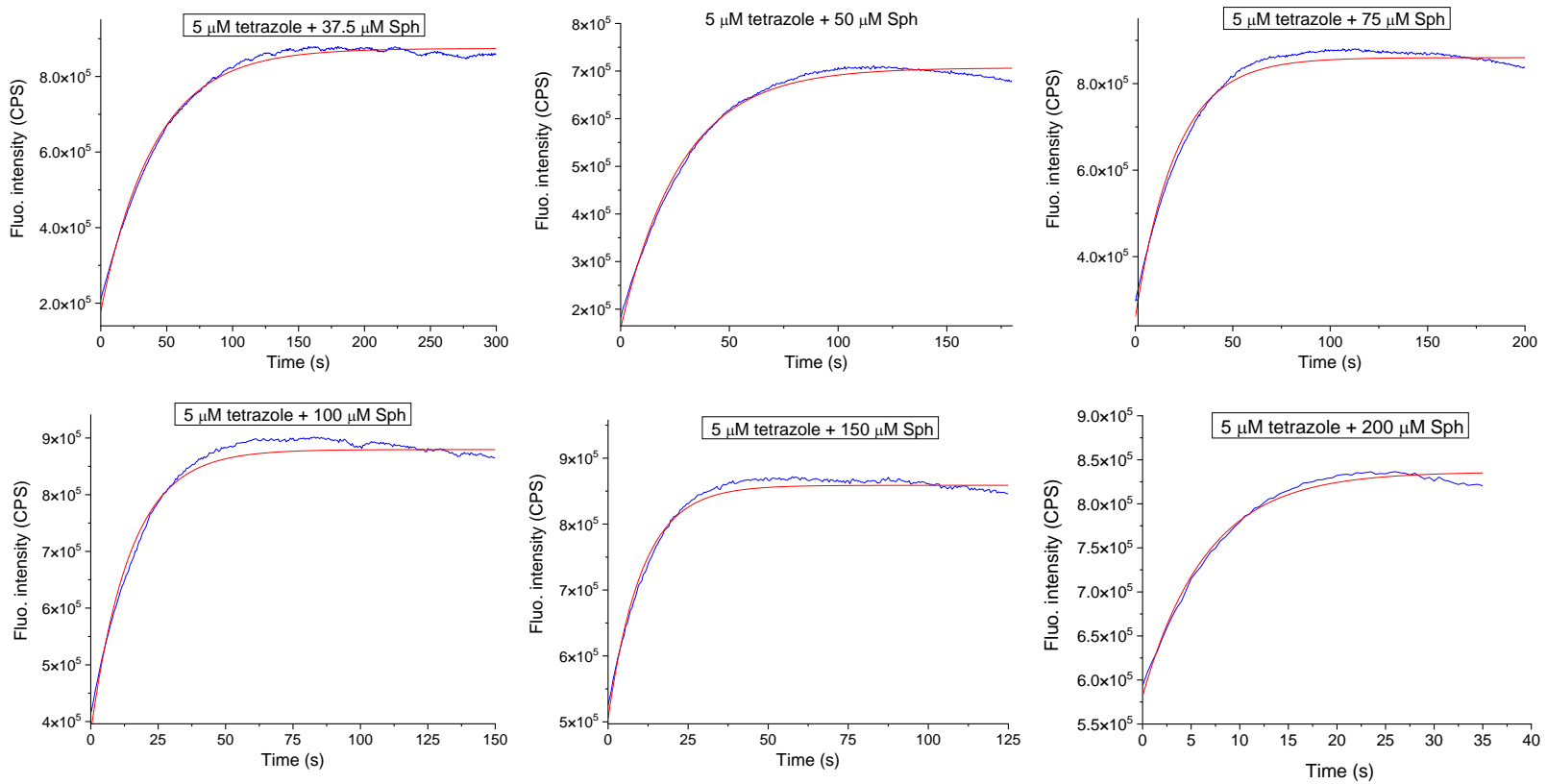

c)

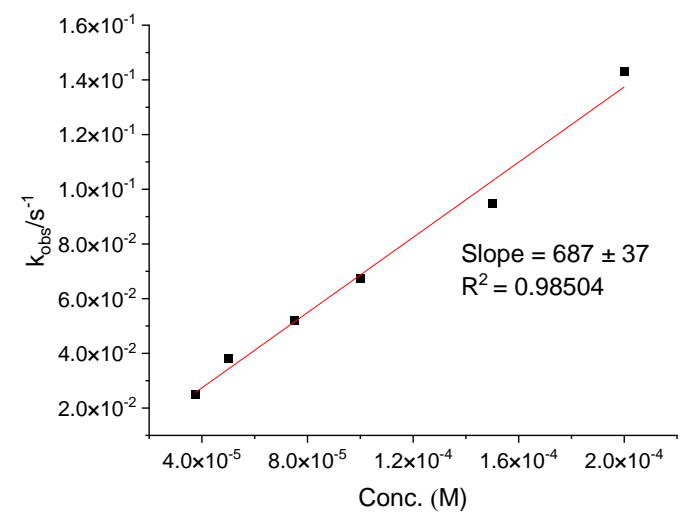

Figure S8. Kinetics measurement of the cycloaddition between tetrazole 4 and Sph. A 5- $\mu \mathrm{M}$ tetrazole solution in $500 \mu \mathrm{L} \mathrm{ACN}$ was irradiated at $302 \mathrm{~nm}$ for $15 \mathrm{sec}$ prior to addition to a solution of 37.5-200 $\mu \mathrm{M}$ Sph in $500 \mu \mathrm{L}$ phosphate buffer. (a) Reaction scheme. (b) Time-course of the reaction between tetrazole 4 and Sph. The pyrazoline product was monitored using fluorescence $\left(\lambda_{\text {ex }}=405 \mathrm{~nm}\right)$. Measurements were repeated three times. The pyrazoline product formation was fitted to an exponential rise to maximum equation, $y=\left(y_{0}-a\right) e^{\text {kobs } t}+a$, to give $k_{\text {obs. }}$ (c) Plot of $k_{\text {obs }} v s$. Sph concentration. The second-order rate constant, $k_{2}$, was determined to be $687 \pm 37$ based on the slope of the fitted curve. 
a)

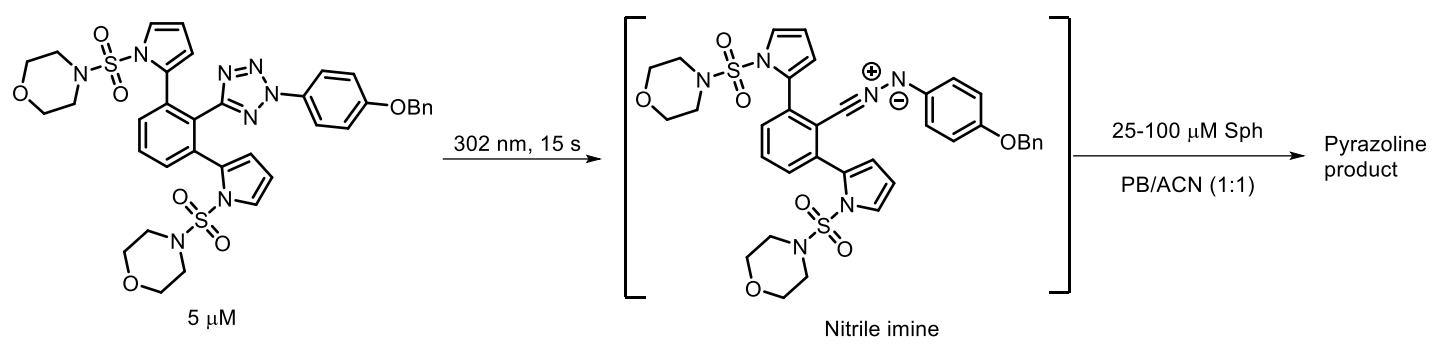

b)
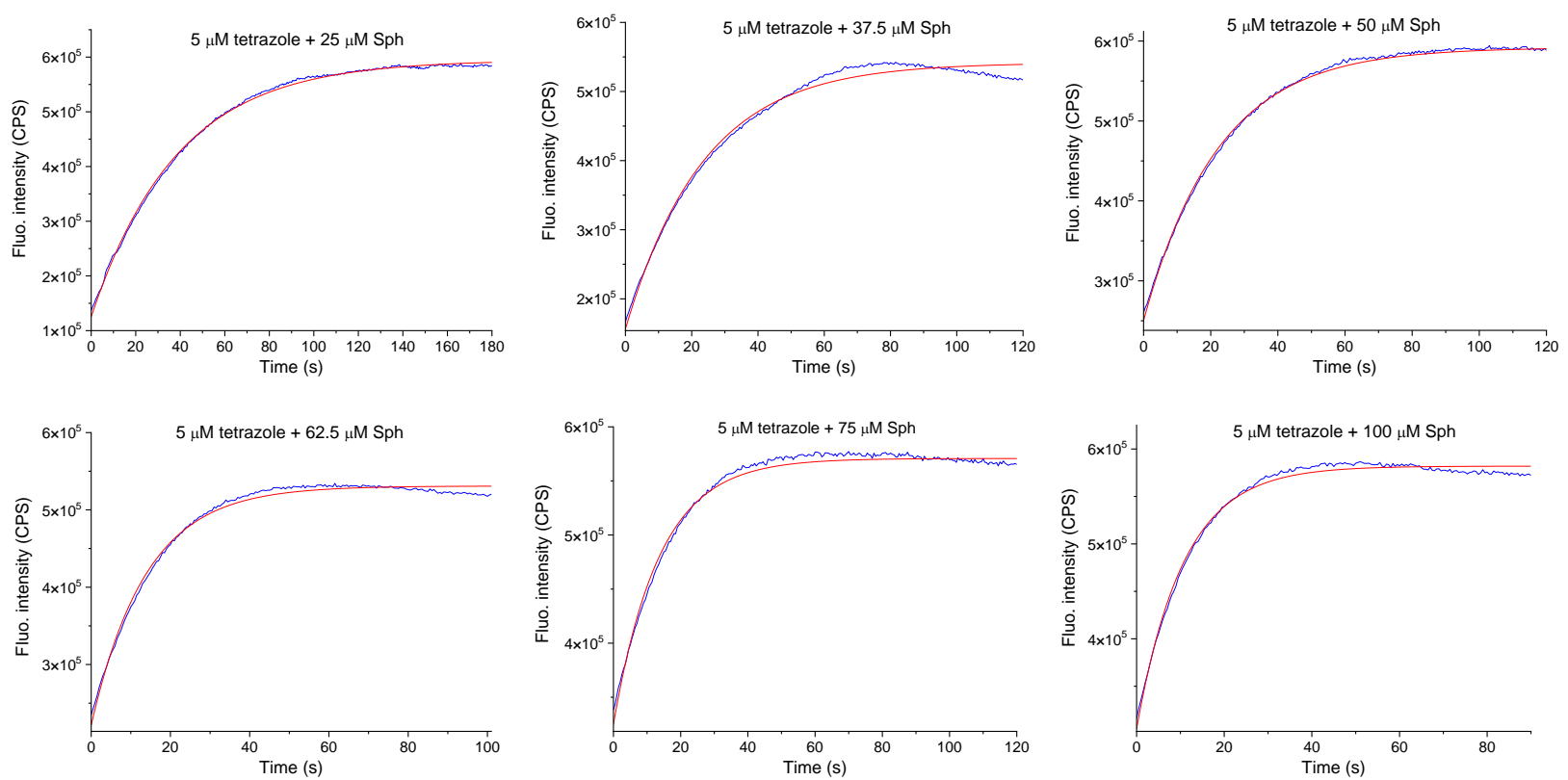

c)

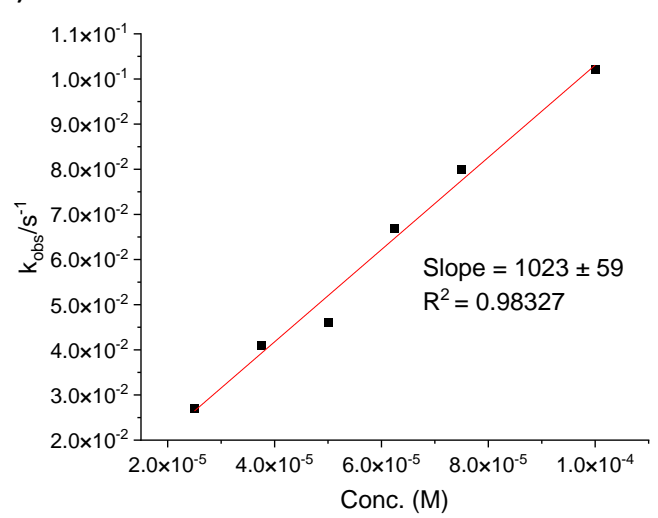

Figure S9. Kinetics measurement of the cycloaddition between tetrazole $\mathbf{5}$ and Sph. A 5- $\mu \mathrm{M}$ tetrazole solution in $500 \mu \mathrm{L} \mathrm{ACN}$ was irradiated at $302 \mathrm{~nm}$ for $15 \mathrm{sec}$ prior to addition to a solution of 25-100 $\mu \mathrm{M}$ Sph in $500 \mu \mathrm{L}$ phosphate buffer. (a) Reaction scheme. (b) Time-course of the reaction between tetrazole 5 and Sph. The pyrazoline product was monitored using fluorescence $\left(\lambda_{\text {ex }}=405 \mathrm{~nm}\right)$. Measurements were repeated three times. The pyrazoline product formation was fitted to an exponential rise to maximum equation, $\mathrm{y}=\left(\mathrm{y}_{0}-\mathrm{a}\right) \mathrm{e}^{\text {kobs } t}+\mathrm{a}$, to give $k_{\mathrm{obs}}$. (c) Plot of $k_{\mathrm{obs}} \mathrm{vs.} \mathrm{Sph}$ concentration. The second-order rate constant, $k_{2}$, was determined to be $1023 \pm 59$ based on the slope of the fitted curve. 
a)
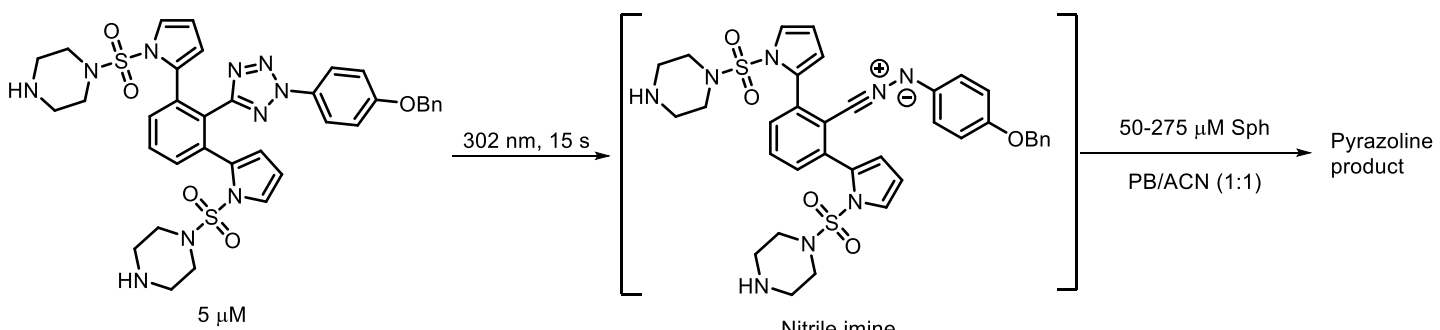

b)
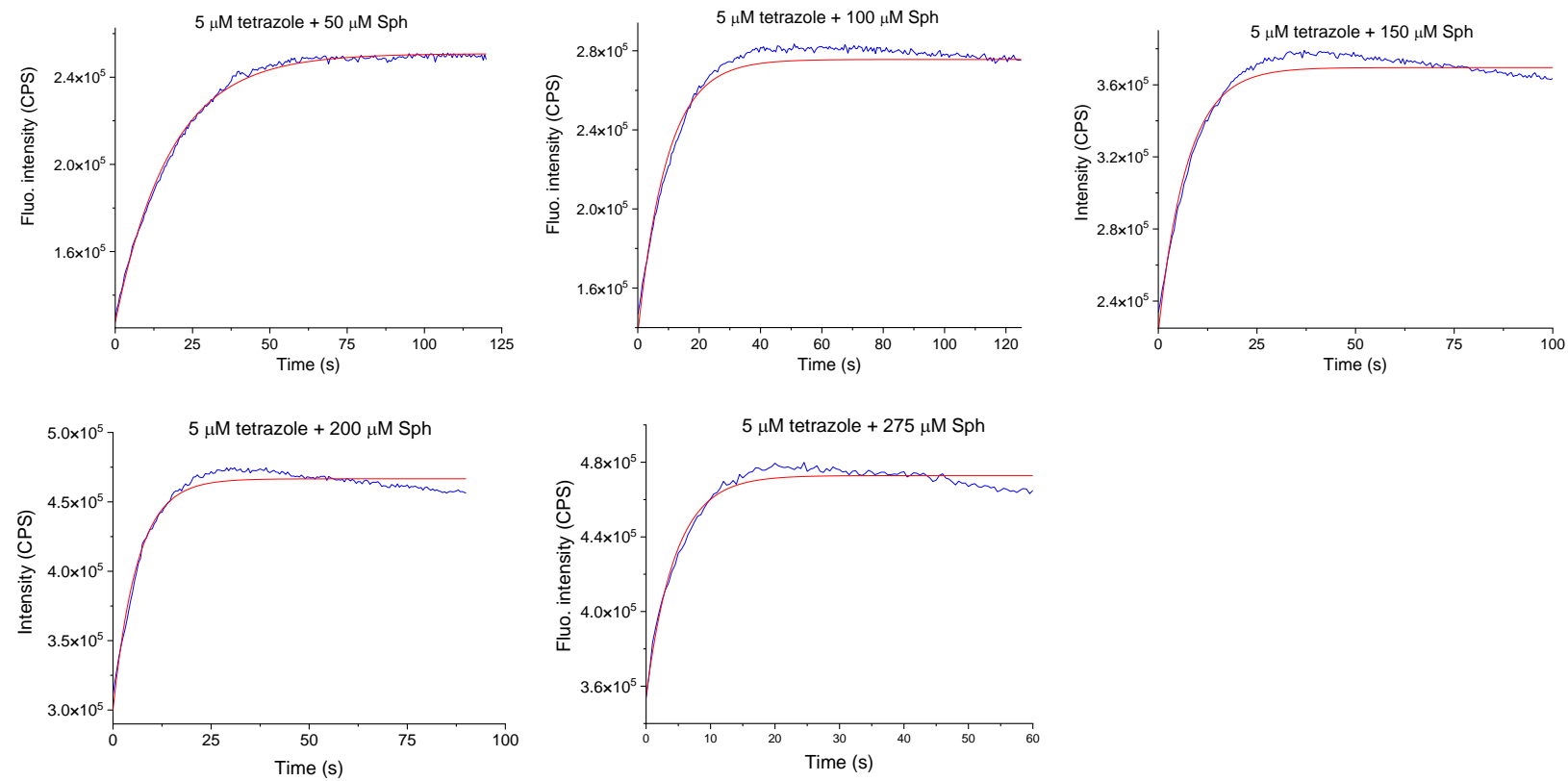

c)

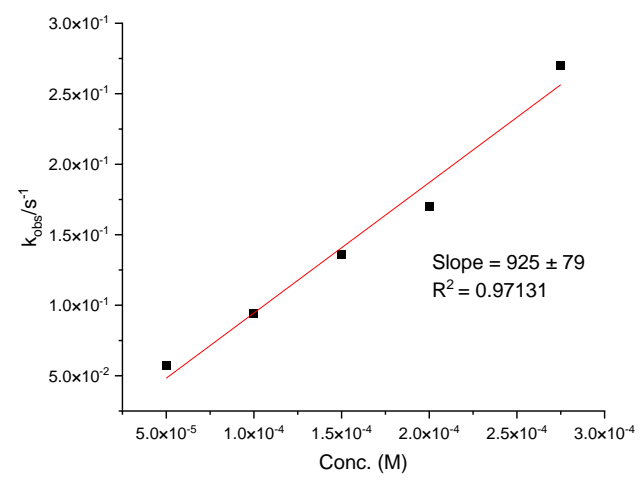

Figure S10. Kinetics measurement of the cycloaddition between tetrazole 6 and Sph. A 5- $\mu \mathrm{M}$ tetrazole solution in $500 \mu \mathrm{L} \mathrm{ACN}$ was irradiated at $302 \mathrm{~nm}$ for $15 \mathrm{sec}$ prior to addition to a solution of $50-275 \mu \mathrm{M}$ Sph in $500 \mu \mathrm{L}$ phosphate buffer. (a) Reaction scheme. (b) Time-course of the reaction between tetrazole 6 and Sph. The pyrazoline product was monitored using fluorescence $\left(\lambda_{\text {ex }}=405 \mathrm{~nm}\right)$. Measurements were repeated three times. The pyrazoline product formation was fitted to an exponential rise to maximum equation, $y=\left(y_{0}-a\right) e^{\text {kobs } t}+a$, to give $k_{o b s .}$ (c) Plot of $k_{\text {obs }} v s$. Sph concentration. The second-order rate constant, $k_{2}$, was determined to be $925 \pm 79$ based on the slope of the fitted curve. 
a)

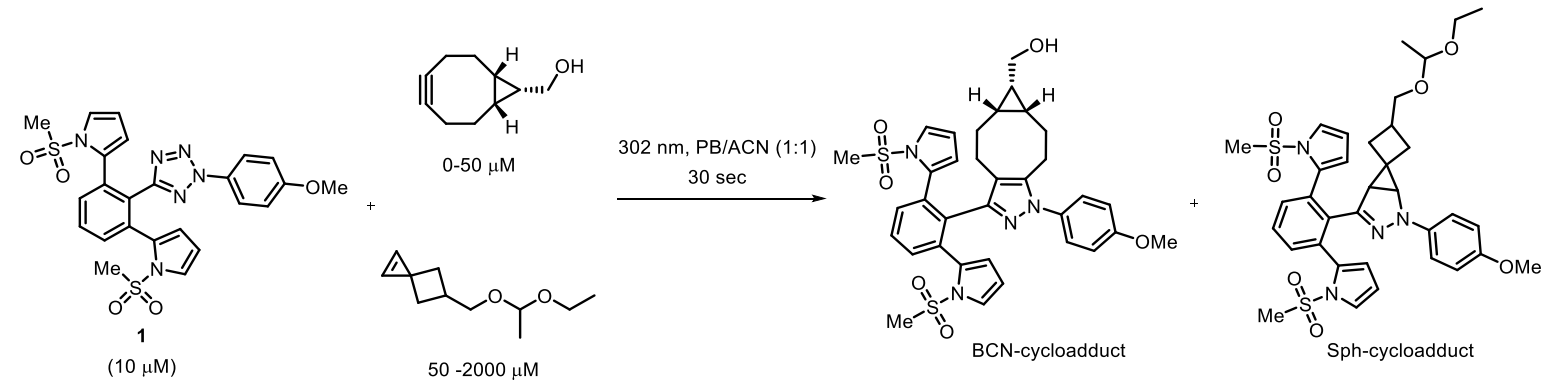

b)

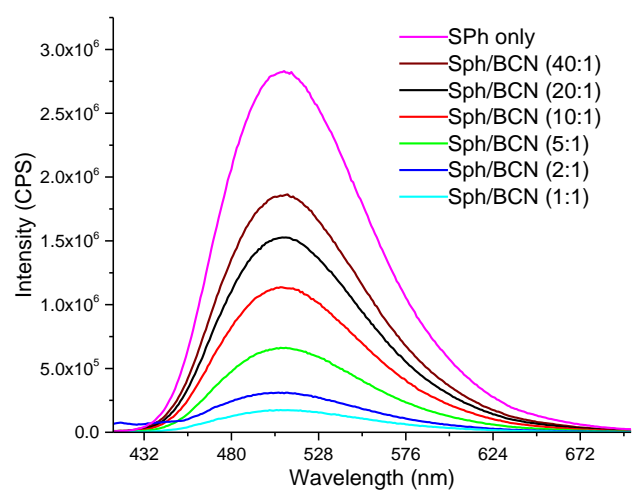

c)

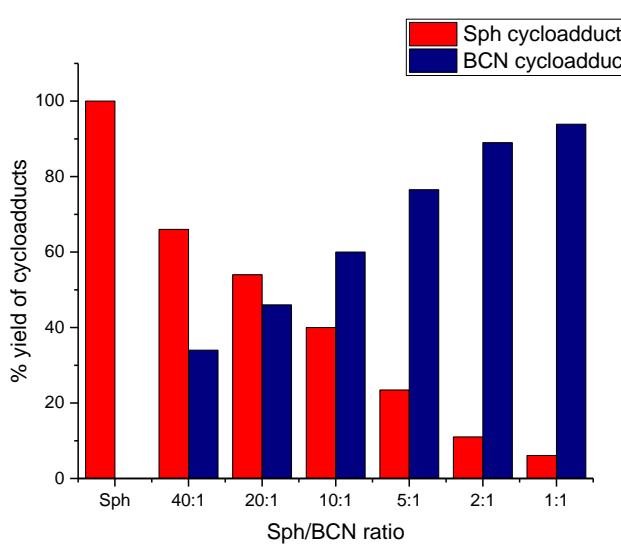

d)

\begin{tabular}{|c|c|c|c|c|c|}
\hline Entry & {$[\mathrm{Sph}] /[\mathrm{BCN}]$ (ratio) } & $\begin{array}{c}\mathrm{BCN} / \mathrm{Sph} \\
\text { cycloadduct ratio }\end{array}$ & $k_{2, \mathrm{BCN}} / k_{2, \mathrm{Sph}}$ & $k_{2, B C N}\left(M^{-1} s^{-1}\right)$ & $\begin{array}{c}\text { Average } \pm \text { SD } \\
\left(\mathrm{M}^{-1} \mathrm{~s}^{-1}\right)\end{array}$ \\
\hline 1 & $50 \mu \mathrm{M}$ Sph & - & - & - & \multirow{7}{*}{$39,200 \pm 4,600$} \\
\hline 2 & $50 \mu \mathrm{M}$ Sph:50 $\mu \mathrm{M}$ BCN (1:1) & $94: 6$ & $15.7: 1$ & 36,400 & \\
\hline 3 & $100 \mu \mathrm{M}$ Sph:50 $\mu \mathrm{M}$ BCN (2:1) & $89: 11$ & $16.2: 1$ & 37,600 & \\
\hline 4 & $250 \mu \mathrm{M}$ Sph:50 $\mu \mathrm{M}$ BCN (5:1) & 77:23 & $16.7: 1$ & 38,800 & \\
\hline 5 & $500 \mu \mathrm{M}$ Sph:50 $\mu \mathrm{M}$ BCN (10:1) & $60: 40$ & $15.0: 1$ & 34,800 & \\
\hline 6 & $1000 \mu \mathrm{M}$ Sph:50 $\mu \mathrm{M}$ BCN (20:1) & $46: 54$ & $17.0: 1$ & 39,500 & \\
\hline 7 & $2000 \mu \mathrm{M}$ Sph:50 $\mu \mathrm{M}$ BCN $(40: 1)$ & $34: 66$ & 20.6:1 & 47,800 & \\
\hline
\end{tabular}

Figure S11. Comparison of $B C N$ reactivity to Sph in the photoclick reaction with tetrazole 1 based on pyrazoline fluorescence. A solution of $10 \mu \mathrm{M}$ tetrazole 1 and excess Sph (50 $\mu \mathrm{M}-2000 \mu \mathrm{M})$ in 1:1 PB/ACN was photo-irradiated $(302 \mathrm{~nm})$ in the absence or presence of $\mathrm{BCN}(50 \mu \mathrm{M})$ for $30 \mathrm{sec}$. The formation of pyrazoline product was monitored by fluorescence; $\lambda_{\text {ex }}=405 \mathrm{~nm}$. (a) Reaction scheme. (b) Fluorescence spectra of the pyrazoline products under various reaction conditions. (c) Plot of cycloadduct formation as a function of $[\mathrm{Sph}] /[\mathrm{BCN}]$. (d) Table showing the reaction conditions and calculation details. The ratio of the cycloaddition rates was calculated as follows: $k_{2, \mathrm{BCN}} / k_{2, \mathrm{Sph}}=\frac{P_{S p h} / P_{B C N}}{[\mathrm{Sph}] /[\mathrm{BCN}]}$. 
a)

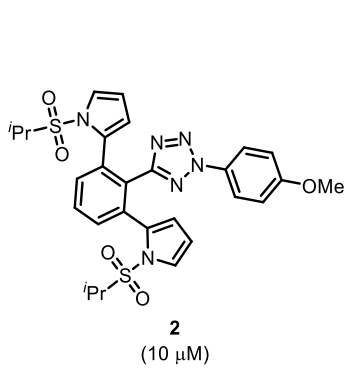

b)

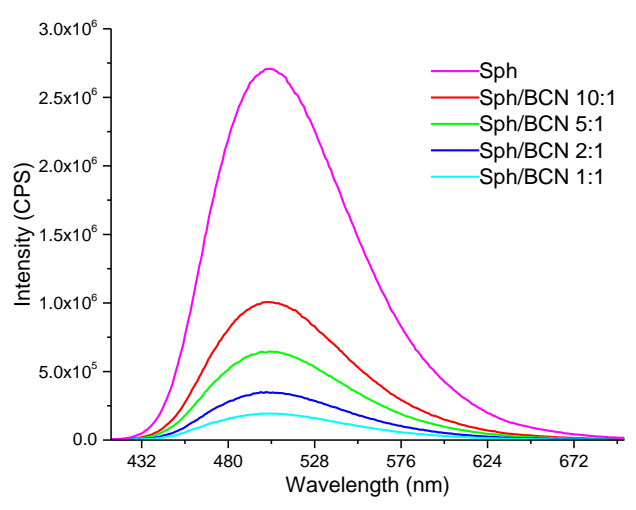

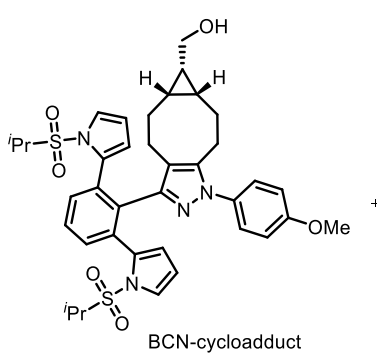

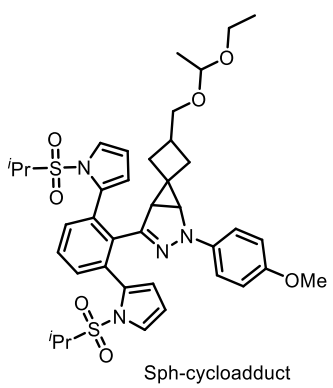

c)

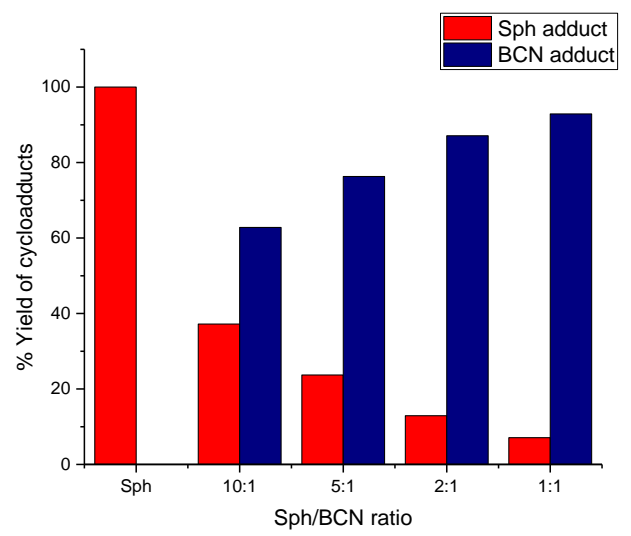

d)

\begin{tabular}{|c|c|c|c|c|c|}
\hline Entry & {$[\mathrm{Sph}] /[\mathrm{BCN}]$ (ratio) } & $\begin{array}{l}\mathrm{BCN} / \mathrm{Sph} \\
\text { cycloadduct } \\
\text { ratio }\end{array}$ & $k_{2, \mathrm{BCN}} / k_{2, \mathrm{Sph}}$ & $k_{2, \mathrm{BCN}}\left(\mathrm{M}^{-1} \mathrm{~s}^{-1}\right)$ & $\begin{array}{c}\text { Average } \pm \text { SD } \\
\left(\mathrm{M}^{-1} \mathrm{~s}^{-1}\right)\end{array}$ \\
\hline 1 & $50 \mu \mathrm{M}$ Sph & - & - & - & \multirow{5}{*}{$20,800 \pm 2,60 c$} \\
\hline 2 & $50 \mu \mathrm{M}$ Sph:50 $\mu \mathrm{M}$ BCN (1:1) & $93: 7$ & 13.3:1 & 18,600 & \\
\hline 3 & $100 \mu \mathrm{M}$ Sph:50 $\mu \mathrm{M}$ BCN (2:1) & $87: 13$ & 13.4:1 & 18,700 & \\
\hline 4 & $250 \mu \mathrm{M}$ Sph:50 $\mu \mathrm{M}$ BCN (5:1) & $76: 24$ & 15.8:1 & 22,100 & \\
\hline 5 & $500 \mu \mathrm{M}$ Sph:50 $\mu \mathrm{M}$ BCN $(10: 1)$ & 63: 37 & 17.0:1 & 23,800 & \\
\hline
\end{tabular}

Figure S12. Comparison of $\mathrm{BCN}$ reactivity to Sph in the photoclick reaction with tetrazole 2 based on pyrazoline fluorescence. A solution of $10 \mu \mathrm{M}$ tetrazole 2 and excess Sph (50 $\mu \mathrm{M}-500 \mu \mathrm{M})$ in 1:1 PB/ACN was photo-irradiated $(302 \mathrm{~nm})$ in the absence or presence of BCN $(50 \mu \mathrm{M})$ for $30 \mathrm{sec}$. The formation of pyrazoline product was monitored by fluorescence; $\lambda_{\mathrm{ex}}=405 \mathrm{~nm}$. (a) Reaction scheme. (b) Fluorescence spectra of the pyrazoline products under various reaction conditions. (c) Plot of cycloadduct formation as a function of $[\mathrm{Sph}] /[\mathrm{BCN}]$. (d) Table showing the reaction conditions and calculation details. The ratio of the cycloaddition rates was calculated as follows: $k_{2, \mathrm{BCN}} / k_{2, \mathrm{Sph}}=\frac{P_{S p h} / P_{B C N}}{[\mathrm{Sph}] /[\mathrm{BCN}]}$. 
a)

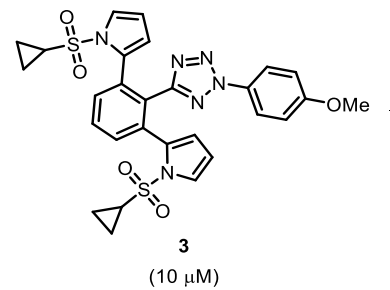

b)

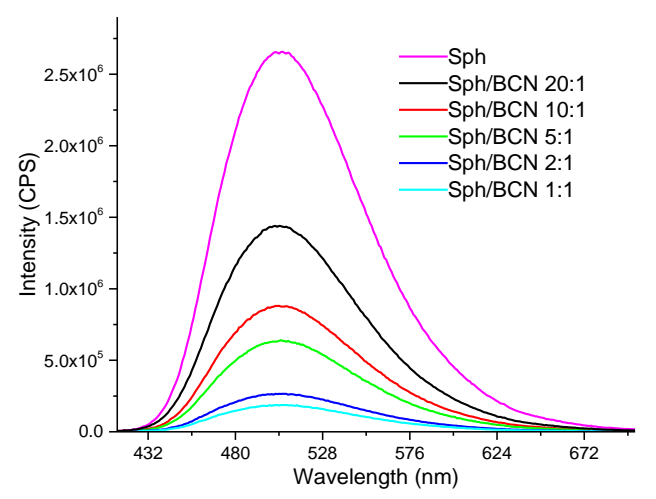

$302 \mathrm{~nm}, \mathrm{~PB} / \mathrm{ACN}(1: 1)$ $30 \mathrm{sec}$

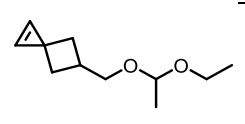

$50-1000 \mu \mathrm{M}$

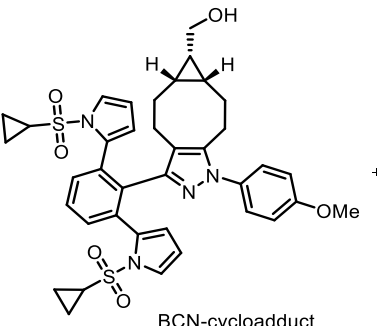

BCN-cycloadduct

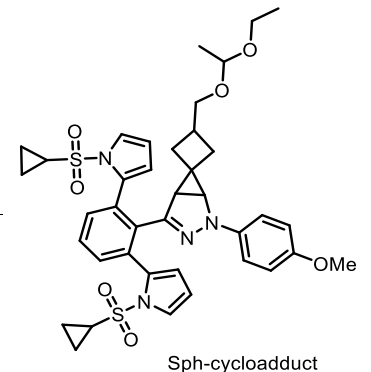

Sph-cycloadduct

c)

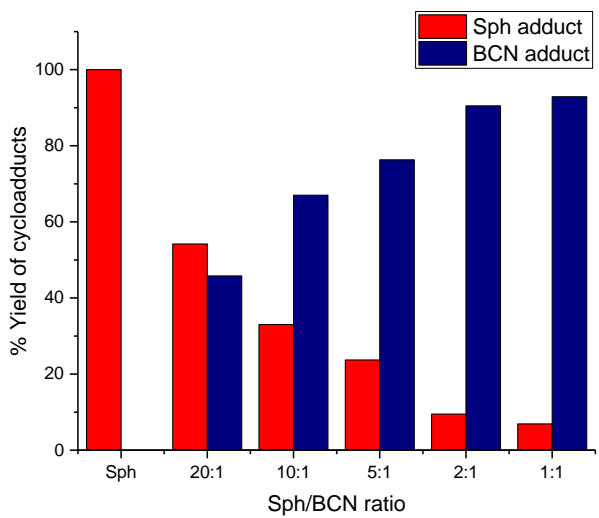

d)

\begin{tabular}{|c|c|c|c|c|c|}
\hline Entry & {$[\mathrm{Sph}] /[\mathrm{BCN}]$ (ratio) } & $\begin{array}{c}\mathrm{BCN} / \mathrm{Sph} \\
\text { cycloadduct } \\
\text { ratio }\end{array}$ & $k_{2, \mathrm{BCN}} / k_{2, \mathrm{Sph}}$ & $k_{2, B C N}\left(M^{-1} s^{-1}\right)$ & $\begin{array}{c}\text { Average } \pm \text { SD } \\
\left(\mathrm{M}^{-1} \mathrm{~S}^{-1}\right)\end{array}$ \\
\hline 1 & $50 \mu \mathrm{M}$ Sph & - & - & - & \multirow{6}{*}{$21,000 \pm 3,200$} \\
\hline 2 & $50 \mu \mathrm{M}$ Sph:50 $\mu \mathrm{M}$ BCN (1:1) & $93: 7$ & 13.3:1 & 16,600 & \\
\hline 3 & $100 \mu \mathrm{M}$ Sph:50 $\mu \mathrm{M}$ BCN (2:1) & $90: 10$ & 18.0:1 & 22,400 & \\
\hline 4 & $250 \mu \mathrm{M}$ Sph:50 $\mu \mathrm{M}$ BCN (5:1) & $76: 24$ & 15.8:1 & 19,700 & \\
\hline 5 & $500 \mu \mathrm{M}$ Sph:50 $\mu \mathrm{M}$ BCN (10:1) & $67: 33$ & $20.3: 1$ & 25,300 & \\
\hline 6 & $1000 \mu \mathrm{M}$ Sph:50 $\mu \mathrm{M}$ BCN $(20: 1)$ & 46:54 & 17.0:1 & 21,200 & \\
\hline
\end{tabular}

Figure S13. Comparison of $\mathrm{BCN}$ reactivity to Sph in the photoclick reaction with tetrazole $\mathbf{3}$ based on pyrazoline fluorescence. A solution of $10 \mu \mathrm{M}$ tetrazole 3 and excess Sph (50 $\mu \mathrm{M}-1000 \mu \mathrm{M})$ in 1:1 PB/ACN was photo-irradiated $(302 \mathrm{~nm})$ in the absence or presence of BCN $(50 \mu \mathrm{M})$ for $30 \mathrm{sec}$. The formation of pyrazoline product was monitored by fluorescence; $\lambda_{\mathrm{ex}}=405 \mathrm{~nm}$. (a) Reaction scheme. (b) Fluorescence spectra of the pyrazoline products under various reaction conditions. (c) Plot of cycloadduct formation as a function of $[\mathrm{Sph}] /[\mathrm{BCN}]$. (d) Table showing the reaction conditions and calculation details. The ratio of the cycloaddition rates was calculated as follows: $k_{2, \mathrm{BCN}} / k_{2, \mathrm{Sph}}=\frac{P_{S p h} / P_{B C N}}{[\mathrm{Sph}] /[\mathrm{BCN}]}$. 
a)

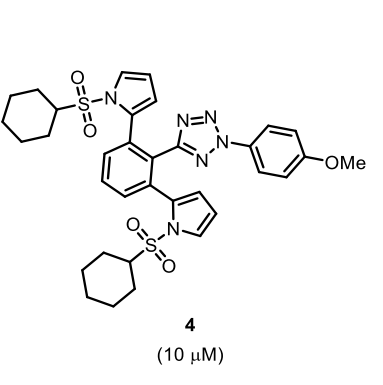

b)

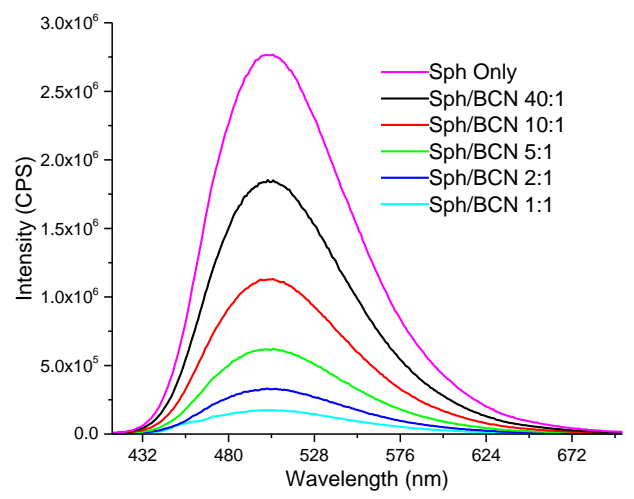

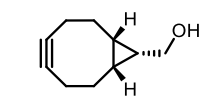

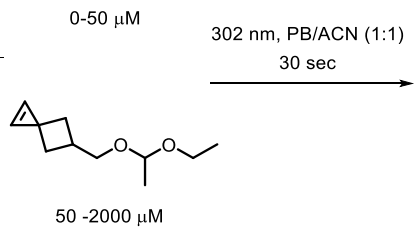

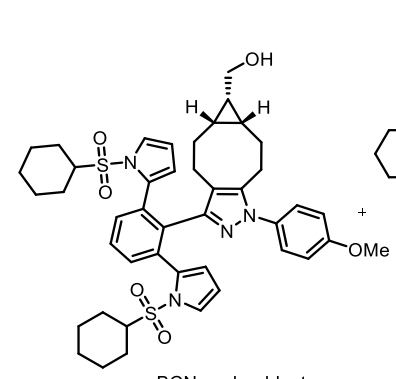

$\mathrm{BCN}$-cycloadduct

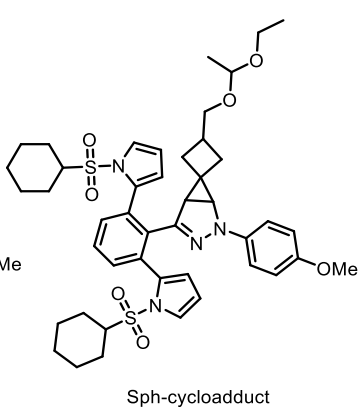

c)

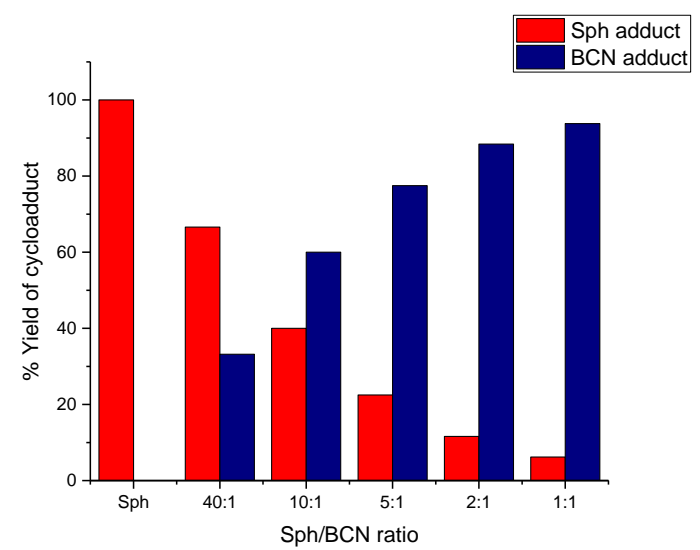

d)

\begin{tabular}{|c|c|c|c|c|c|}
\hline Entry & {$[\mathrm{Sph}] /[\mathrm{BCN}]$ (ratio) } & $\begin{array}{l}\mathrm{BCN} / \mathrm{Sph} \\
\text { cycloadduct } \\
\text { ratio }\end{array}$ & $k_{2, \mathrm{BCN}} / k_{2, \mathrm{Sph}}$ & $k_{2, \mathrm{BCN}}\left(\mathrm{M}^{-1} \mathrm{~s}^{-1}\right)$ & $\begin{array}{c}\text { Average } \pm \text { SD } \\
\left(\mathrm{M}^{-1} \mathrm{~s}^{-1}\right)\end{array}$ \\
\hline 1 & $50 \mu \mathrm{M}$ Sph & - & - & - & \multirow{6}{*}{$11,400 \pm 1,400$} \\
\hline 2 & $50 \mu \mathrm{M}$ Sph:50 $\mu \mathrm{M}$ BCN (1:1) & $94: 6$ & $15.7: 1$ & 10,800 & \\
\hline 3 & $100 \mu \mathrm{M}$ Sph:50 $\mu \mathrm{M}$ BCN (2:1) & $88: 12$ & $14.7: 1$ & 10,100 & \\
\hline 4 & $250 \mu \mathrm{M}$ Sph:50 $\mu \mathrm{M}$ BCN (5:1) & $78: 22$ & 17.7:1 & 12,200 & \\
\hline 5 & $500 \mu \mathrm{M}$ Sph:50 $\mu \mathrm{M}$ BCN (10:1) & $60: 40$ & $15.0: 1$ & 10,300 & \\
\hline 6 & $2000 \mu \mathrm{M}$ Sph:50 $\mu \mathrm{M}$ BCN (40:1) & 33:67 & $19.7: 1$ & 13,500 & \\
\hline
\end{tabular}

Figure S14. Comparison of BCN reactivity to Sph in the photoclick reaction with tetrazole 4 based on pyrazoline fluorescence. A solution of $10 \mu \mathrm{M}$ tetrazole 4 and excess Sph (50 $\mu \mathrm{M}-2000 \mu \mathrm{M})$ in 1:1 PB/ACN was photo-irradiated $(302 \mathrm{~nm})$ in the absence or presence of BCN $(50 \mu \mathrm{M})$ for $30 \mathrm{sec}$. The formation of pyrazoline product was monitored by fluorescence; $\lambda_{\mathrm{ex}}=405 \mathrm{~nm}$. (a) Reaction scheme. (b) Fluorescence spectra of the pyrazoline products under various reaction conditions. (c) Plot of cycloadduct formation as a function of $[\mathrm{Sph}] /[\mathrm{BCN}]$. (d) Table showing the reaction conditions and calculation details. The ratio of the cycloaddition rates was calculated as follows: $k_{2, \mathrm{BCN}} / k_{2, \mathrm{Sph}}=\frac{P_{S p h} / P_{B C N}}{[\mathrm{Sph}] /[\mathrm{BCN}]}$. 
a)

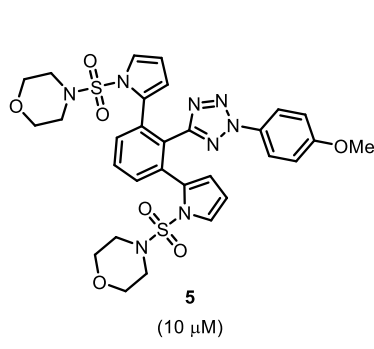

b)
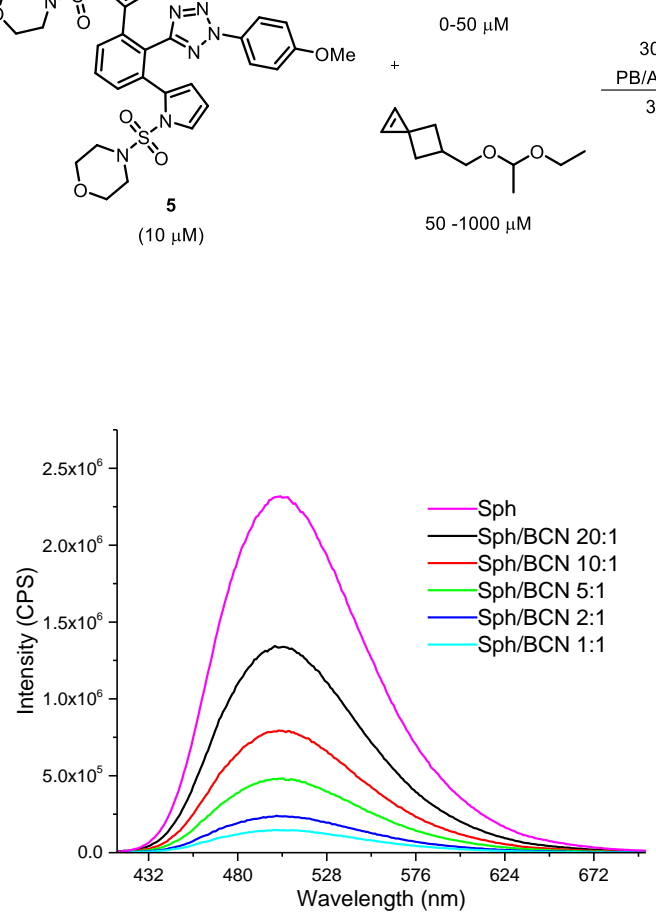

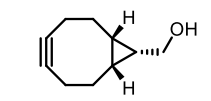

d)

\begin{tabular}{|c|c|c|c|c|c|}
\hline Entry & {$[\mathrm{Sph}] /[\mathrm{BCN}]$ (ratio) } & $\begin{array}{l}\mathrm{BCN} / \mathrm{Sph} \\
\text { cycloadduct } \\
\text { ratio }\end{array}$ & $k_{2, \mathrm{BCN}} / k_{2, \mathrm{Sph}}$ & $k_{2, \mathrm{BCN}}\left(\mathrm{M}^{-1} \mathrm{~s}^{-1}\right)$ & $\begin{array}{c}\text { Average } \pm \text { SD } \\
\left(\mathrm{M}^{-1} \mathrm{~s}^{-1}\right)\end{array}$ \\
\hline 1 & $50 \mu \mathrm{M} \mathrm{Sph}$ & - & - & - & \multirow{6}{*}{$17,700 \pm 2,100$} \\
\hline 2 & $50 \mu \mathrm{M}$ Sph:50 $\mu \mathrm{M}$ BCN (1:1) & $94: 6$ & $15.7: 1$ & 16,100 & \\
\hline 3 & $100 \mu \mathrm{M}$ Sph:50 $\mu \mathrm{M}$ BCN (2:1) & $90: 10$ & $18.0: 1$ & 18,400 & \\
\hline 4 & $250 \mu \mathrm{M}$ Sph:50 $\mu \mathrm{M}$ BCN (5:1) & 79:21 & $18.8: 1$ & 19,200 & \\
\hline 5 & $500 \mu \mathrm{M}$ Sph:50 $\mu \mathrm{M}$ BCN $(10: 1)$ & $66: 34$ & 19.4:1 & 19,800 & \\
\hline 6 & $1000 \mu \mathrm{M}$ Sph:50 $\mu \mathrm{M}$ BCN (20:1) & $42: 58$ & 14.5:1 & 14,800 & \\
\hline
\end{tabular}

Figure S15. Comparison of BCN reactivity to Sph in the photoclick reaction with tetrazole 5 based on pyrazoline fluorescence. A solution of $10 \mu \mathrm{M}$ tetrazole 5 and excess Sph (50 $\mu \mathrm{M}-1000 \mu \mathrm{M})$ in 1:1 PB/ACN was photo-irradiated $(302 \mathrm{~nm})$ in the absence or presence of BCN $(50 \mu \mathrm{M})$ for $30 \mathrm{sec}$. The formation of pyrazoline product was monitored by fluorescence; $\lambda_{\mathrm{ex}}=405 \mathrm{~nm}$. (a) Reaction scheme. (b) Fluorescence spectra of the pyrazoline products under various reaction conditions. (c) Plot of cycloadduct formation as a function of $[\mathrm{Sph}] /[\mathrm{BCN}]$. (d) Table showing the reaction conditions and calculation details. The ratio of the cycloaddition rates was calculated as follows: $k_{2, \mathrm{BCN}} / k_{2, \mathrm{Sph}}=\frac{P_{S p h} / P_{B C N}}{[\mathrm{Sph}] /[\mathrm{BCN}]}$. 
a)

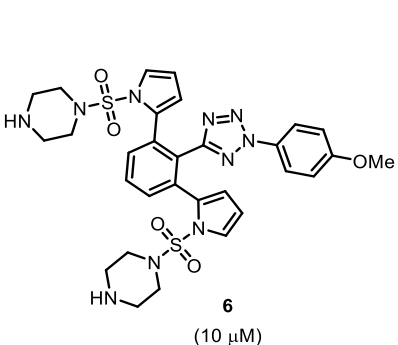

b)

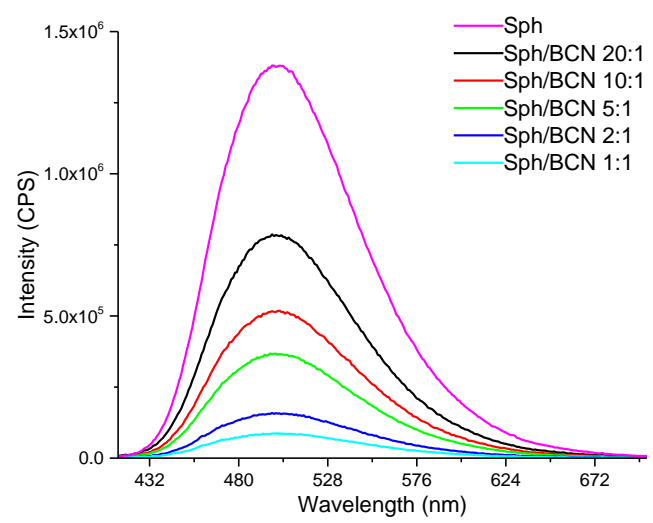

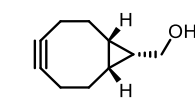

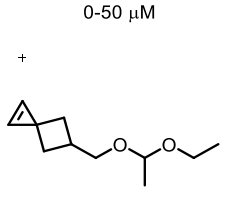

$50-1000 \mu \mathrm{M}$

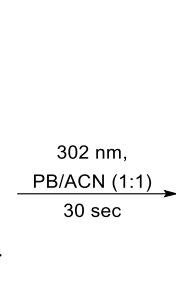

ACN $(1: 1)$

(1)

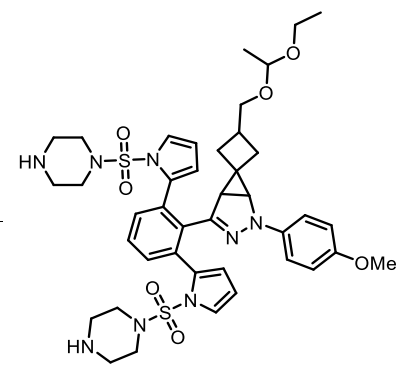

c)

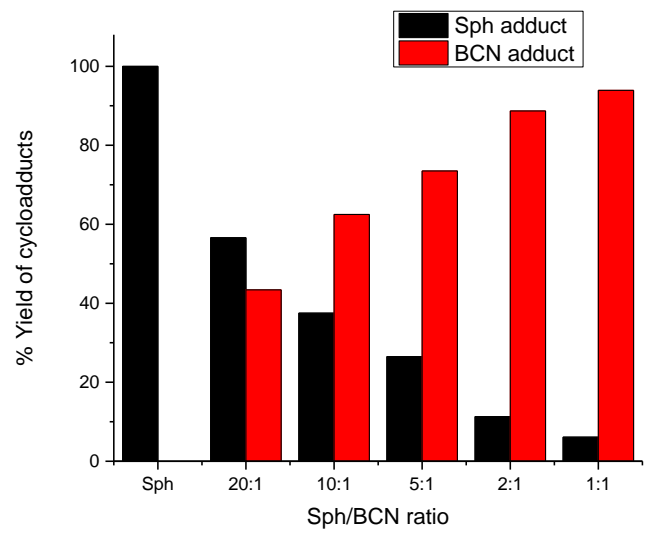

d)

\begin{tabular}{|c|c|c|c|c|c|}
\hline Entry & {$[\mathrm{Sph}] /[\mathrm{BCN}]$ (ratio) } & $\begin{array}{l}\mathrm{BCN} / \mathrm{Sph} \\
\text { cycloadduct } \\
\text { ratio }\end{array}$ & $k_{2, \mathrm{BCN}} / k_{2, \mathrm{Sph}}$ & $k_{2, \mathrm{BCN}}\left(\mathrm{M}^{-1} \mathrm{~s}^{-1}\right)$ & $\begin{array}{c}\text { Average } \pm \text { SD } \\
\quad\left(\mathrm{M}^{-1} \mathrm{~s}^{-1}\right)\end{array}$ \\
\hline 1 & $50 \mu \mathrm{M}$ Sph & - & - & - & \multirow{6}{*}{$14,500 \pm 990$} \\
\hline 2 & $50 \mu \mathrm{M}$ Sph:50 $\mu \mathrm{M}$ BCN (1:1) & $94: 6$ & $15.7: 1$ & 14,500 & \\
\hline 3 & $100 \mu \mathrm{M}$ Sph:50 $\mu \mathrm{M}$ BCN (2:1) & $89: 11$ & $16.2: 1$ & 15,000 & \\
\hline 4 & $250 \mu \mathrm{M}$ Sph:50 $\mu \mathrm{M}$ BCN (5:1) & $74: 26$ & 14.2:1 & 13,100 & \\
\hline 5 & $500 \mu \mathrm{M}$ Sph:50 $\mu \mathrm{M}$ BCN (10:1) & $63: 37$ & $17.0: 1$ & 15,700 & \\
\hline 6 & $1000 \mu \mathrm{M}$ Sph:50 $\mu \mathrm{M}$ BCN (20:1) & 43:57 & 15.1:1 & 14,000 & \\
\hline
\end{tabular}

Figure S16. Comparison of BCN reactivity to Sph in the photoclick reaction with tetrazole 6 based on pyrazoline fluorescence. A solution of $10 \mu \mathrm{M}$ tetrazole 6 and excess Sph $(50 \mu \mathrm{M}-1000 \mu \mathrm{M})$ in 1:1 PB/ACN was photo-irradiated $(302 \mathrm{~nm})$ in the absence or presence of BCN $(50 \mu \mathrm{M})$ for $30 \mathrm{sec}$. The formation of pyrazoline product was monitored by fluorescence; $\lambda_{\mathrm{ex}}=405 \mathrm{~nm}$. (a) Reaction scheme. (b) Fluorescence spectra of the pyrazoline products under various reaction conditions. (c) Plot of cycloadduct formation as a function of $[\mathrm{Sph}] /[\mathrm{BCN}]$. (d) Table showing the reaction conditions and calculation details. The ratio of the cycloaddition rates was calculated as follows: $k_{2, \mathrm{BCN}} / k_{2, \mathrm{Sph}}=\frac{P_{S p h} / P_{B C N}}{[\mathrm{Sph}] /[\mathrm{BCN}]}$. 


\section{Activation Strain Analysis}

Activation strain analysis (ASA) decomposes $\Delta E$ of a reaction in terms of $\Delta E_{\text {strain, }}$ the energy required to deform reactants from their relaxed geometry to the one they have at the point of the reaction coordinate path, usually a positive energy, and $\Delta E_{\text {int }}$, the gain of energy due to the interaction between the two moieties. We have analyzed the contribution of these energy variations at the transition state (TS), considering the reactant complex $(\mathrm{R})$ as the reference state and fragmenting the adducts in two moieties: nitrile imine (NI) and Sph/BCN. The ASA results are shown in Table S4. It is noted that, $\Delta E, \Delta E_{\text {strain, }}$, and $\Delta E_{\text {int }}$ contain the solvation energy contribution, and that the ASA uses only electronic energies $(E)$, not enthalpies $(H)$ or Gibbs free energies (G). The lower barrier for the BCN-NI interaction is due to the lower strain energy required to deform the moieties. On the other hand, while Sph has a larger $\Delta E_{\text {int }}$, the larger strain energy required for the reaction to proceed offsets this interaction-based stabilization. These results confirm our previous considerations based on the geometrical distortion of the TS.

Table S4. Activation strain analysis performed using the $\omega B 97 x-D / 6-311++G(d, p) / S M D($ water) level of theory on geometries optimized using the B3LYP-D3/6-311+G(d)/SMD(water) level of theory. $\Delta G$ of the activation barriers are reported as well for comparison. All values are in $\mathrm{kcal} / \mathrm{mol}$.

\begin{tabular}{|c|c|c|c|c|c|c|}
\hline $\mathrm{R} \rightarrow \mathrm{TS}$ & $\Delta E_{\text {strain }}$ & $\Delta E_{\text {strain }}$ & $\begin{array}{c}\Delta E_{\text {strain }} \\
\text { (Total) }\end{array}$ & $\Delta E_{\text {int }}$ & $\Delta E$ & $\Delta G$ \\
\hline $\mathrm{Sph}-\mathrm{NI}$ & 3.68 & 13.36 & 17.04 & -7.68 & 9.36 & 11.02 \\
\hline $\mathrm{BCN}-\mathrm{NI}$ & 1.37 & 9.47 & 10.85 & -2.11 & 8.74 & 9.80 \\
\hline
\end{tabular}




\section{Preparation of lysozyme-BCN conjugate.}

To 0.6-mL solution of chicken lysozyme ( $300 \mu \mathrm{M}$ in $100 \mathrm{mM} \mathrm{NaH}_{2} \mathrm{PO}_{4}, 25 \mathrm{mM} \mathrm{NaOAc}, p \mathrm{H}$ 8.5) was added ((1R,8S,9S)-bicyclo[6.1.0]non-4-yn-9-yl)methyl (4-nitrophenyl) carbonate (BCN-OCOO-PNP) ${ }^{4} 60 \mu \mathrm{L}, 10$ $\mathrm{mM}$ in DMSO; final concentration = $1 \mathrm{mM}$ ). The mixture was incubated on a rocker at room temperature for $8 \mathrm{~h}$. Excess BCN-OCOO-PNP was removed by a protein spin column using $0.25 \mathrm{M} \mathrm{NH}_{3} \cdot \mathrm{H}_{2} \mathrm{O}$ solution as the eluent. The BCN-modified lysozyme (Lyso-BCN) was characterized by QTOF-LC/MS: Lyso, calcd 14304, found 14305.2 \pm 0.1 ; Lyso-BCN, calcd 14480, found 14481.4 $\pm 0.1 ;$ Lyso-BCN 2 , calcd 14658, found 14657.2 \pm 0.1 .

a) Unmodified lysozyme
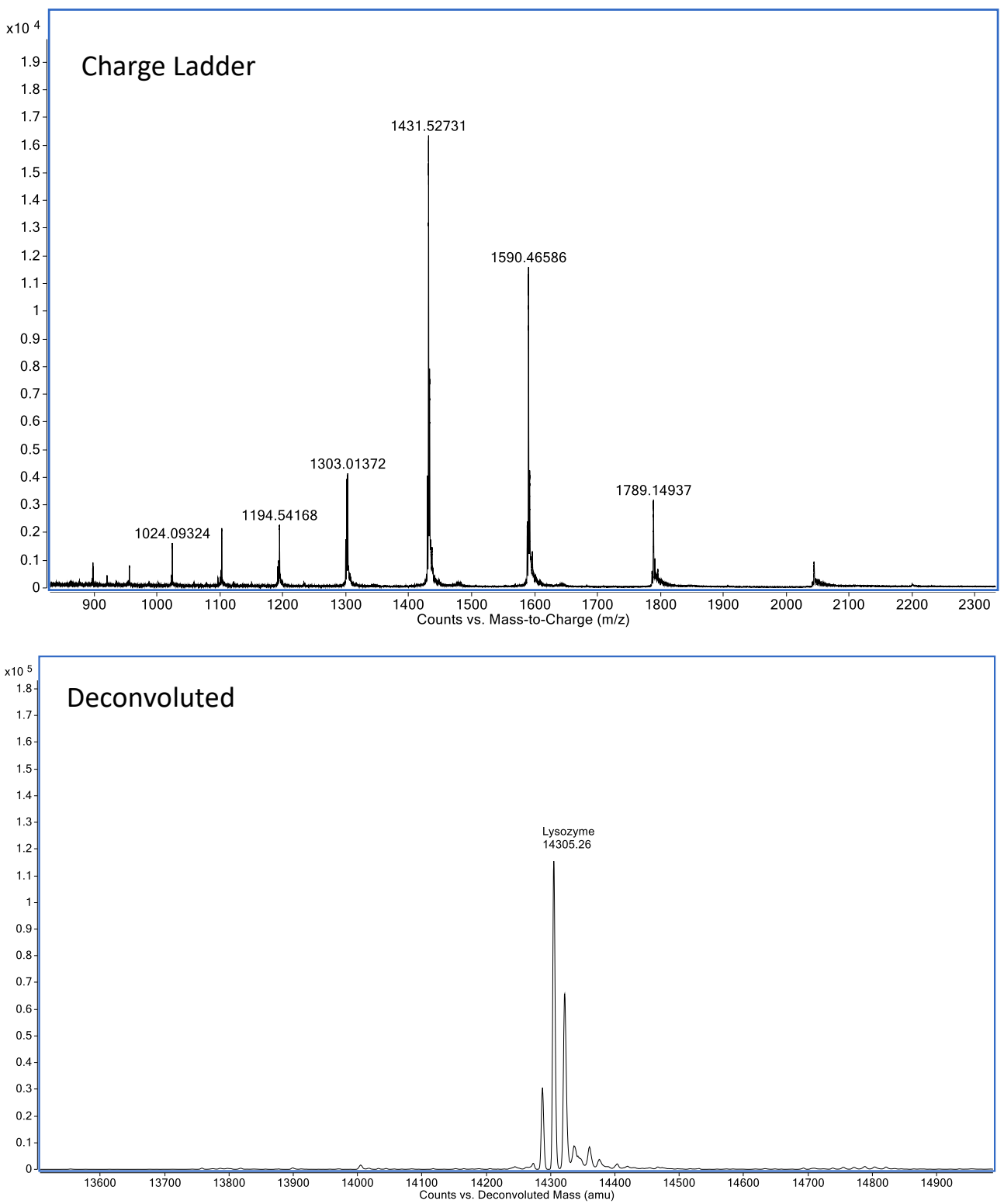
b) Lyso-BCN
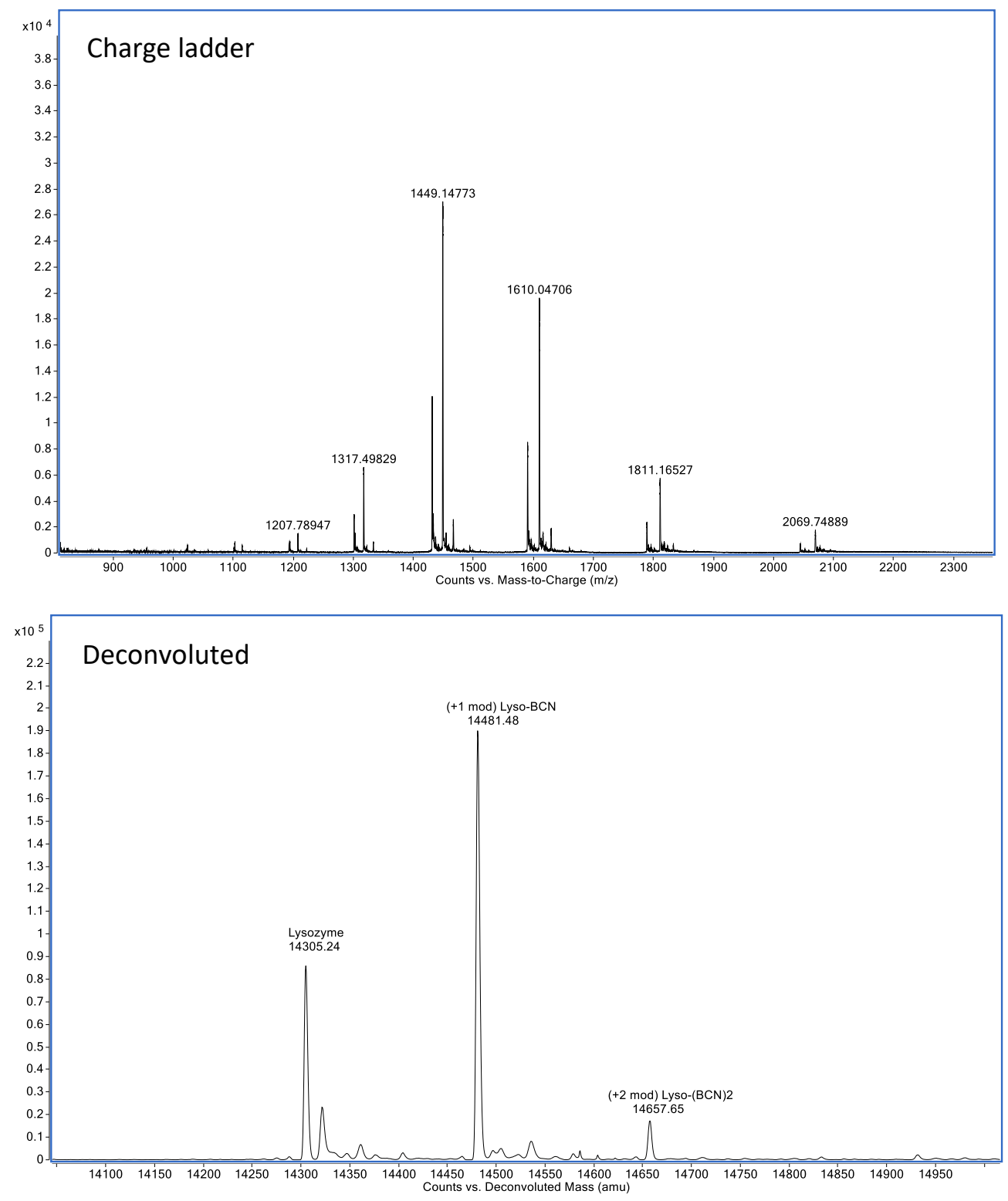

Figure S17. QTOF-LC/MS analysis of (a) unmodified lysozyme and (b) BCN modification of lysozyme after incubation with BCN-OCOO-PNP.

\section{Selective modification of Lyso-BCN by tetrazole 1 via photoclick chemistry.}

A solution of lysozyme-BCN $(1.14 \mu \mathrm{L}, 110 \mu \mathrm{M}$ in PBS; final concentration $=5 \mu \mathrm{M})$ and tetrazole $1(1.25 \mu \mathrm{L}$, $1 \mathrm{mM}$ in acetonitrile; final concentration $=50 \mu \mathrm{M})$ in $25 \mu \mathrm{L}$ PBS/ACN $(1: 1)$ was vortexed. The reaction mixture was irradiated with a handheld $302 \mathrm{~nm}$ UV lamp for 2 sec prior to analysis by QTOF-LC/MS: Lyso- 
Py (mono adduct), calcd. 14490, found $14491.4 \pm 0.1$; Lyso-Py2 (double adduct) calcd 15676, found $15678.2 \pm 0.2$.

a)
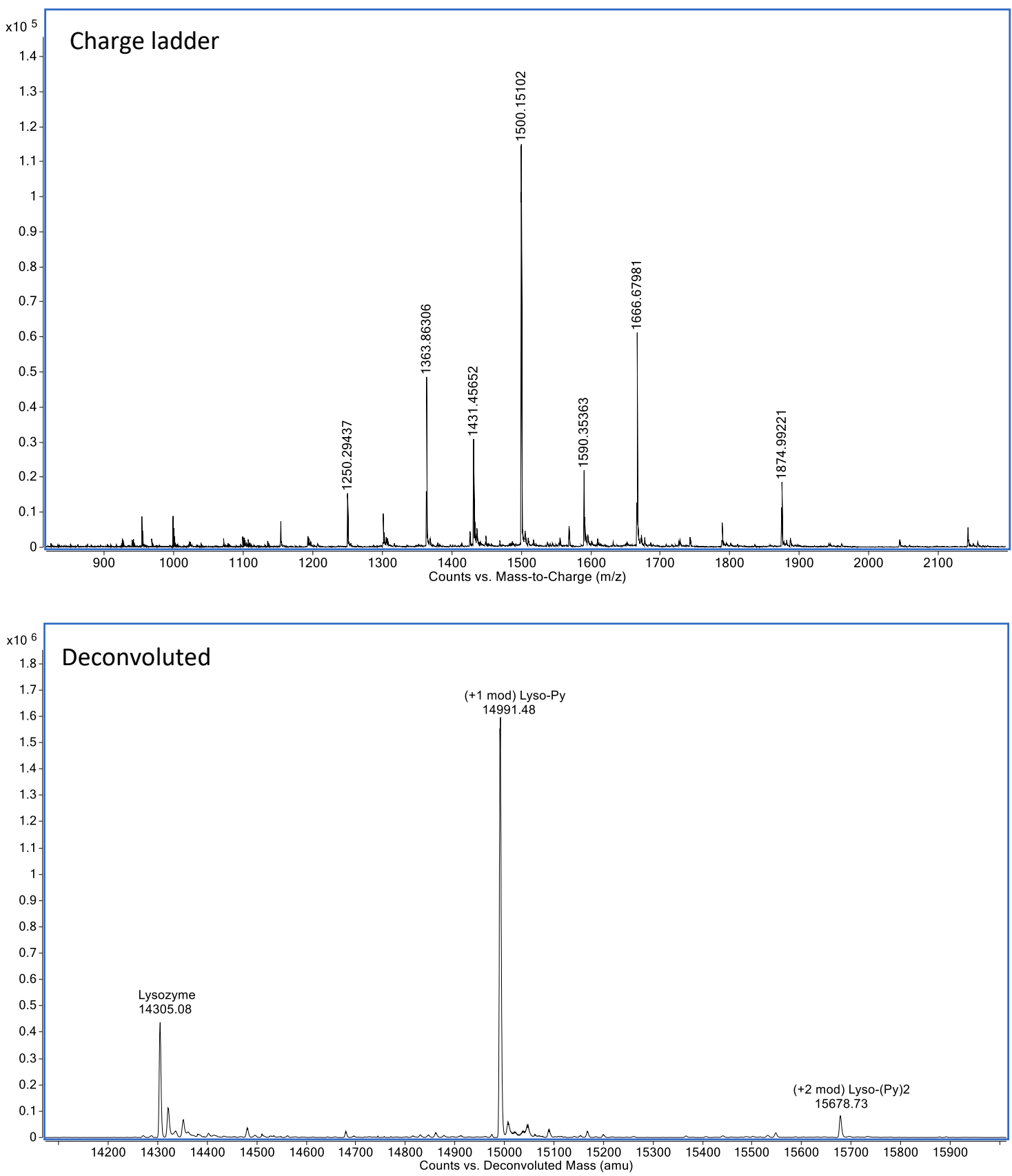
b)
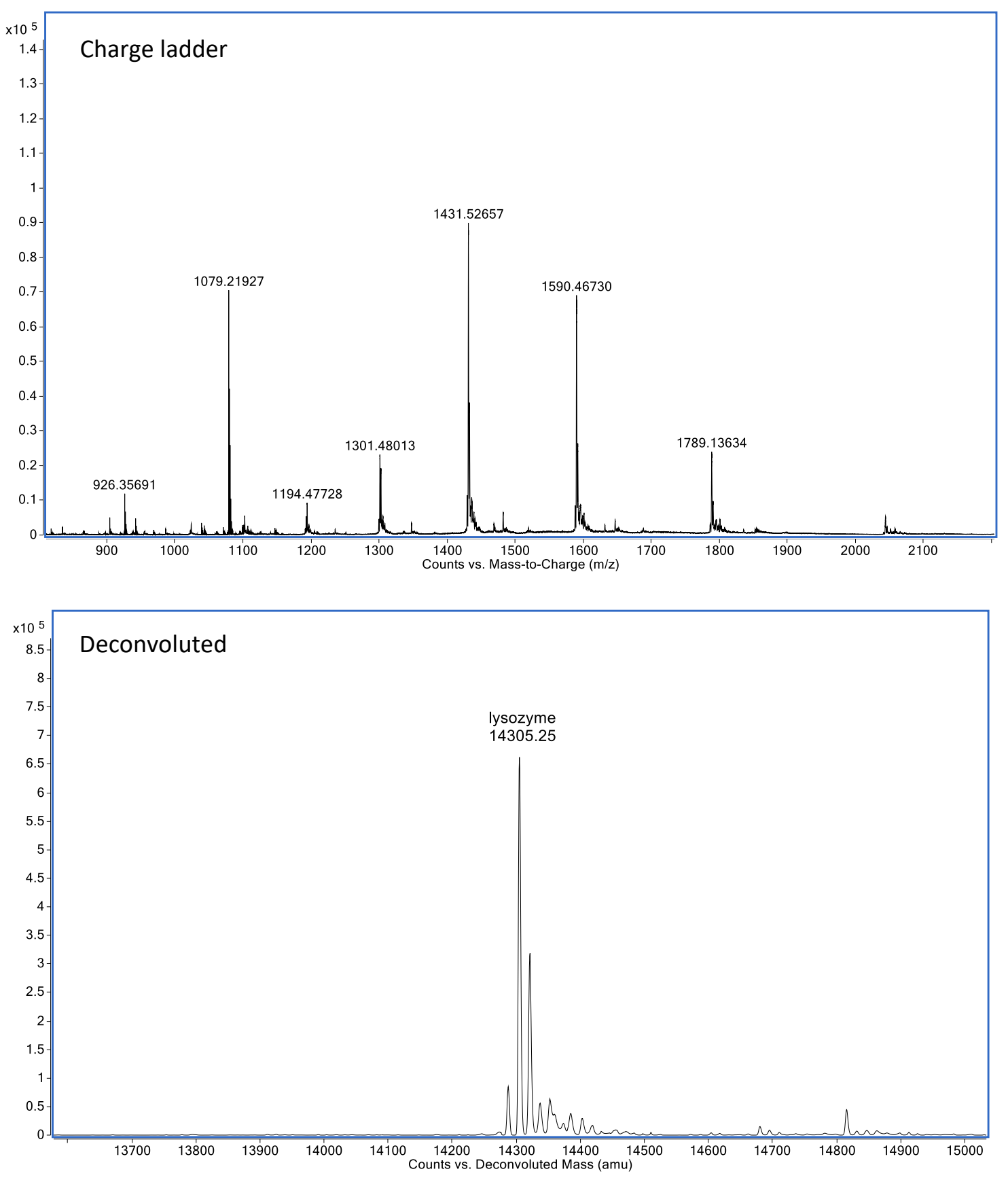

Figure S18. QTOF-LC/MS analysis of (a) lyso-BCN conjugate and (b) unmodified lysozyme after photoclick reaction with tetrazole 1. 
a)

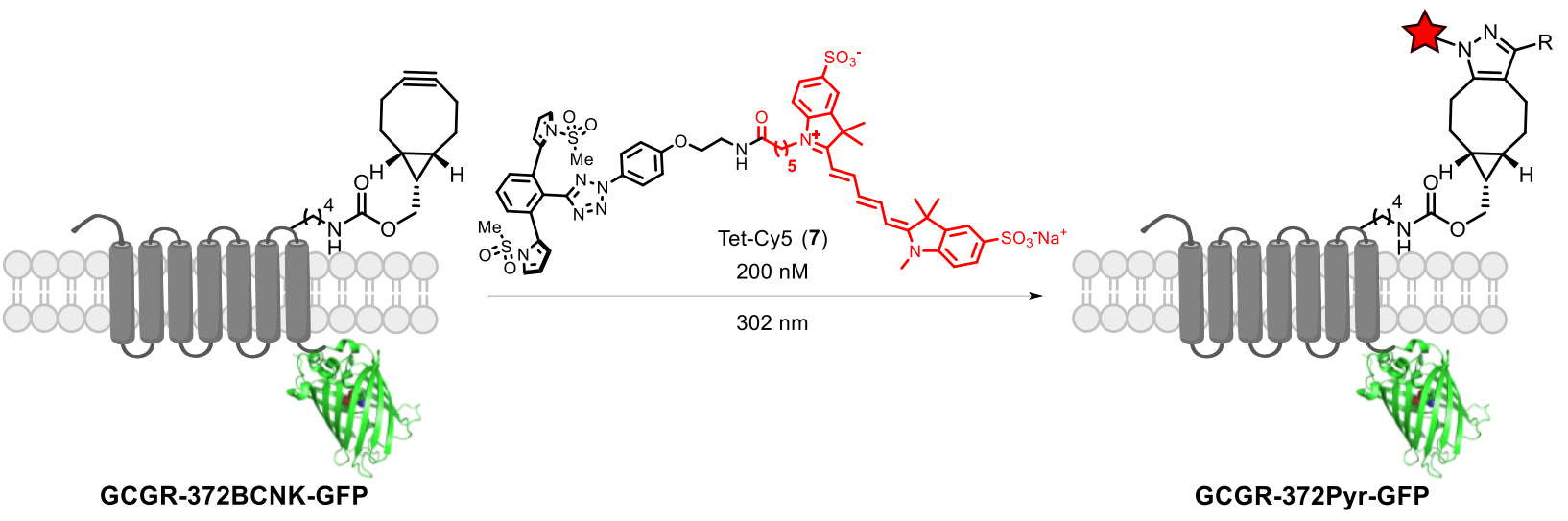

b)

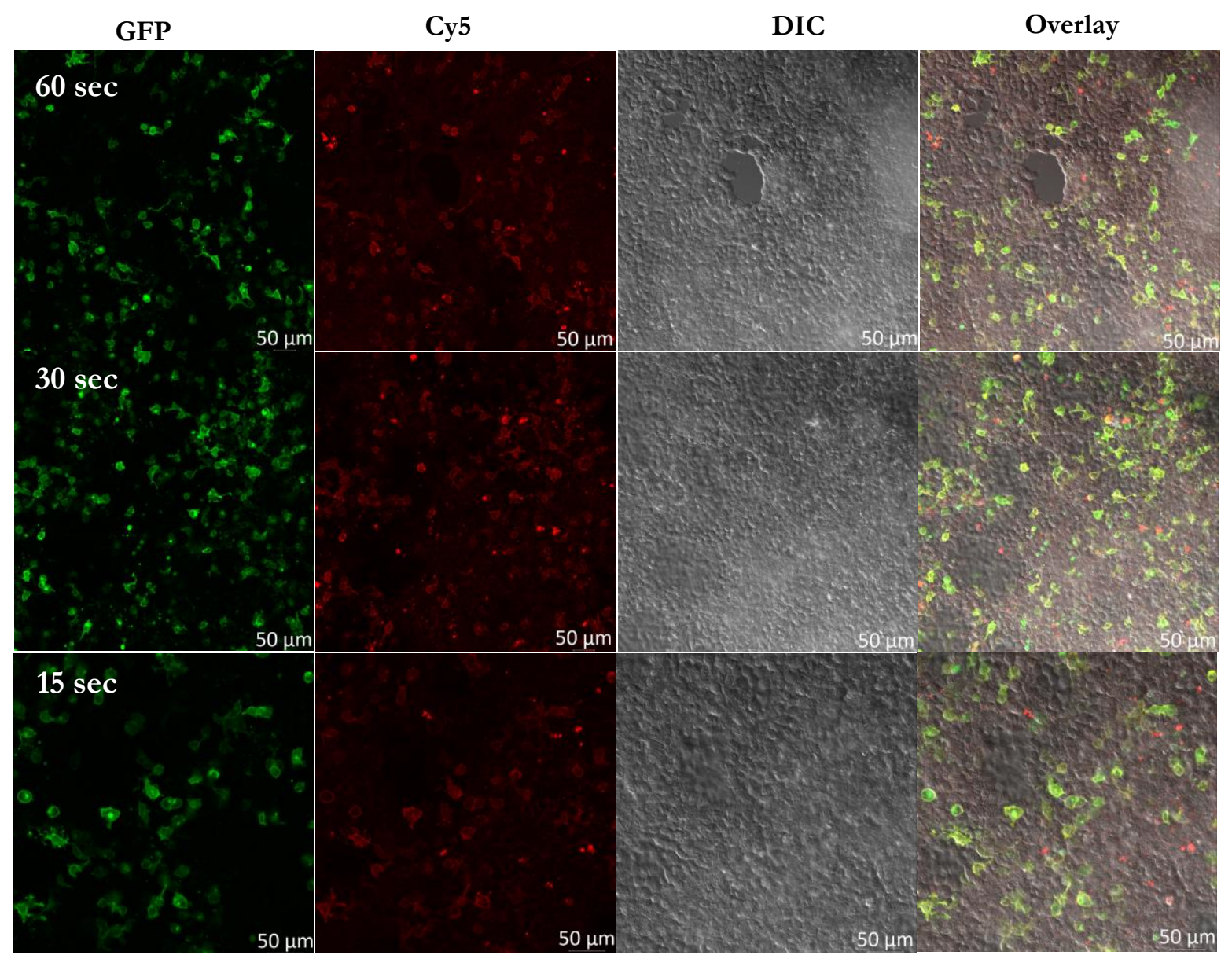

Figure S19. Bioorthogonal fluorescent labeling of GCGR on live HEK293T cells via photoclick chemistry. (a) Scheme for bioorthogonal labeling of a GCGR-GFP mutant encoding BCNK at position-372 with a Cy5funtionalized tetrazole. (b) Confocal micrographs of HEK 293T cells expressing GCGR-H372BCNK-GFP after photoirradiation with a handheld $302 \mathrm{~nm}$ UV lamp for 15, 30, or $60 \mathrm{sec}$ in DMEM medium containing 200 $\mathrm{nM}$ tetrazole-Cy5 (7). Scale bar $=50 \mu \mathrm{m}$. Pearson's coefficient for confocal micrographs from the GFP and Cy5 channels at $60 \mathrm{sec}$ was calculated to be 0.924 using the ImageJ program. 


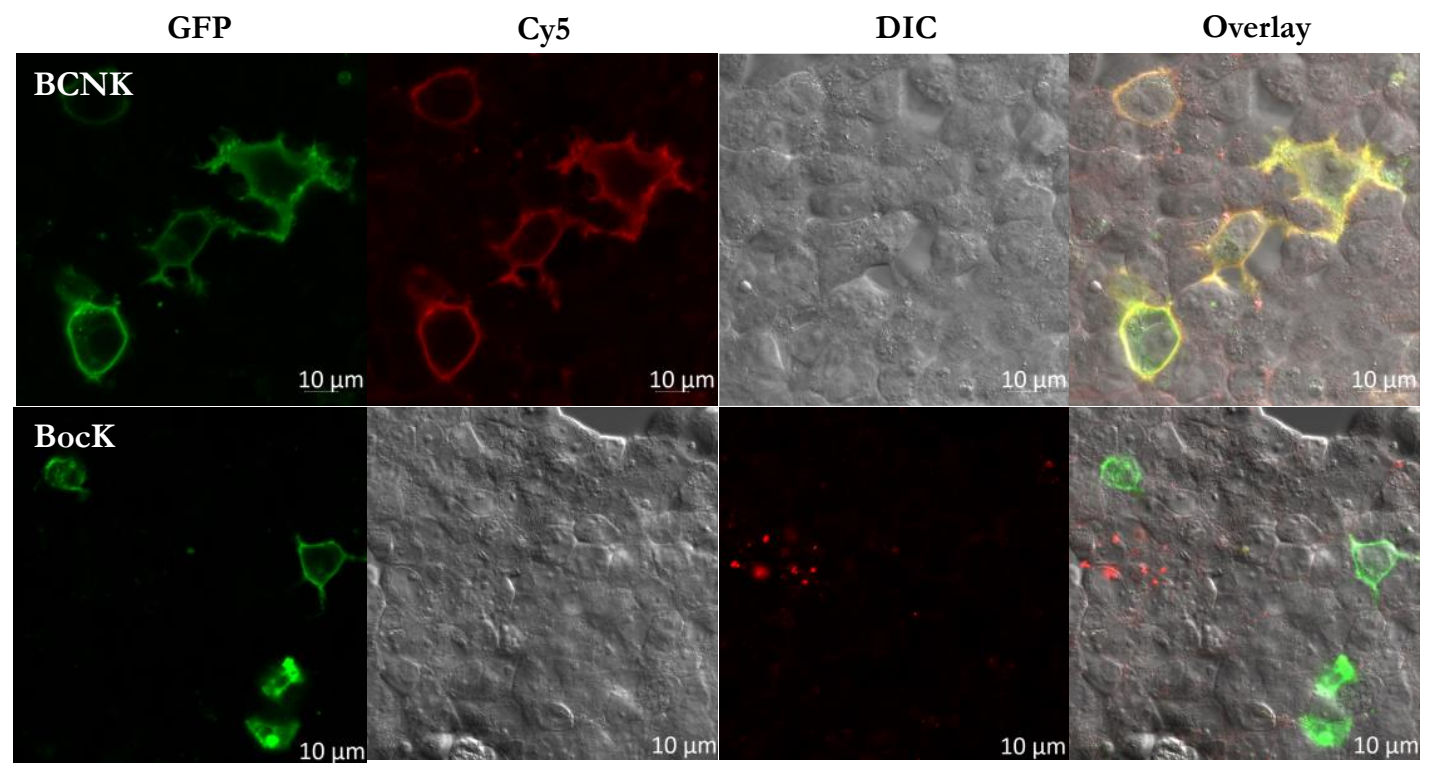

Figure S20. Confocal micrographs of HEK293T cells expressing BCNK or BocK-encoded GCGR-GFP after photoirradiation with a handheld $302 \mathrm{~nm}$ UV lamp for $60 \mathrm{sec}$ in DMEM containing $200 \mathrm{nM}$ tetrazole-Cy5 (7). Scale bar $=10 \mu \mathrm{m}$. Pearson's Coefficient for BCNK labeling was calculated to be 0.953 using ImageJ.

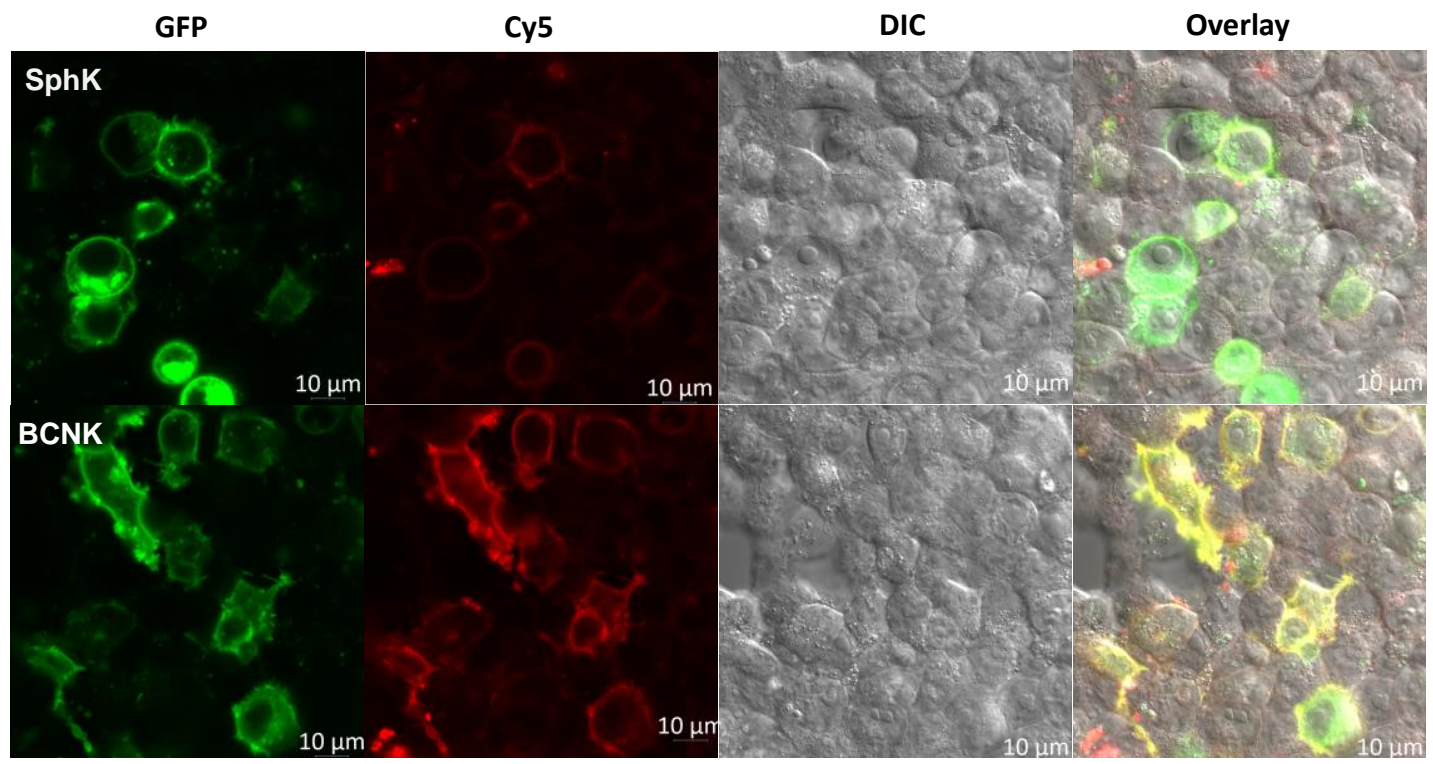

Figure S21. Confocal micrographs of HEK293T cells expressing GCGR-H372SphK/BCNK-GFP after photo irradiation with a handheld $302 \mathrm{~nm}$ UV lamp for $60 \mathrm{sec}$ in DMEM containing $200 \mathrm{nM}$ tetrazole-Cy5 (7). Scale bar $=10 \mu \mathrm{m}$. 
a)

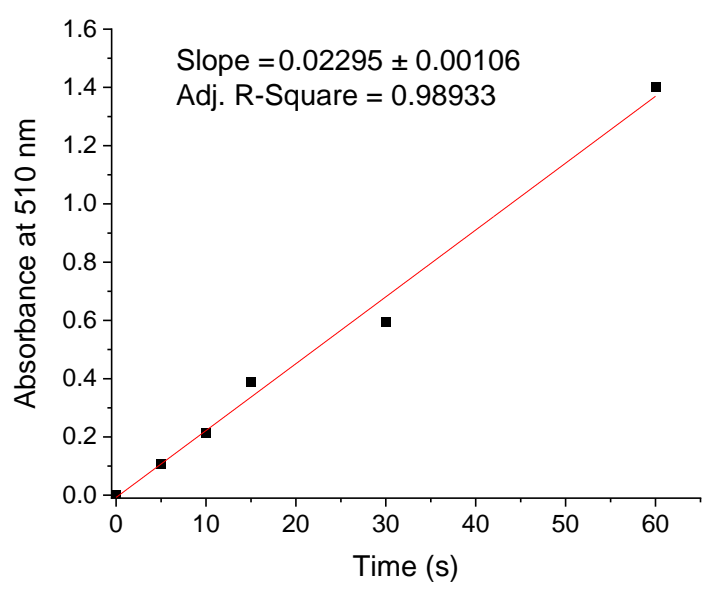

b)

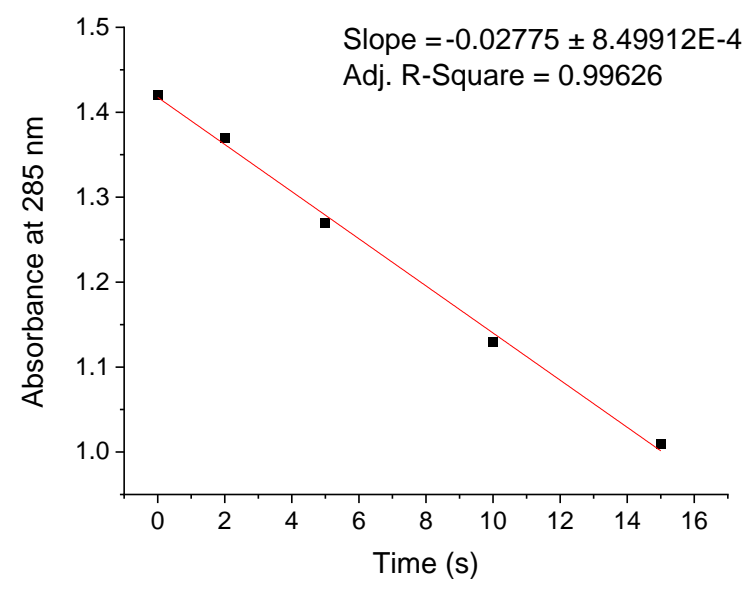

Figure S22. Determination of quantum yield for photoinduced ring rupture of tetrazole 1 using the potassium ferrioxalate-based chemical actinometer. ${ }^{5}$ (a) Time course of absorbance change of $\mathrm{Fe}^{2}-1,10$ phenanthroline complex at $510 \mathrm{~nm}$ upon 302-nm irradiation. (b) Time course of absorption change of tetrazole 1. The solutions of $100 \mu \mathrm{M}$ of tetrazole 1 and $5 \mathrm{mM}$ of dimethyl fumarate in ACN/PB (1:1) in quartz tubes were photoirradiated at $302 \mathrm{~nm}$ for a fixed time before absorbance measurement. The quantum yield for $302 \mathrm{~nm}$ light-induced ring rupture of tetrazole 1 was calculated to be 0.13 . 


\section{General Information}

Solvents and chemicals were purchased from commercial sources and used directly without further purification. Sph was synthesized by following our previous report. ${ }^{6}$ Flash chromatography was performed either manually with SiliCycle P60 silica gel (40-63 $\mu \mathrm{m}, 60 \AA$ ) or an automatic Yamazen AKROS flash system equipped with SiliaSep HP pre-packed columns. ${ }^{1} \mathrm{H}$ NMR spectra were recorded with Inova-300, -400 or $500 \mathrm{MHz}$ spectrometers. Chemical shifts were reported in ppm using TMS or deuterated solvents as internal standards (TMS, 0.00; $\mathrm{CDCl}_{3}, 7.26 ; \mathrm{CD}_{3} \mathrm{OD}, 3.31$; DMSO- $d_{6}, 2.50$; acetone- $d_{6}, 2.05$ ). Multiplicity was reported as follows: $\mathrm{s}=$ singlet, $\mathrm{d}=$ doublet, $\mathrm{t}=$ triplet, $\mathrm{q}=$ quartet, $\mathrm{m}=$ multiplet, brs $=$ broad. ${ }^{13} \mathrm{C}$ NMR spectra were recorded at $75.4 \mathrm{MHz}$, and chemical shifts were reported in ppm using deuterated solvents as internal standards $\left(\mathrm{CDCl}_{3}, 77.0\right.$; DMSO- $d_{6}, 39.5 ; \mathrm{CD}_{3} \mathrm{OD}, 49.05$; acetone- $\left.d_{6}, 30.0\right)$. UV-Vis absorption spectra were recorded using 1-cm quartz cuvette on a HP-8452 Diode Array Spectrophotometer. Fluorescence spectra were recorded using 1-cm quartz cuvette on a Horiba FluoroMax-4 spectrofluorometer at $25^{\circ} \mathrm{C}$. High-resolution mass spectrometry was performed on a Thermo LTQ-Orbitrap XL mass spectrometer equipped with collision cells for collision induced dissociation. Low resolution mass spectrometry was performed on a Thermo LCQ mass spectrometer.

\section{Experimental Procedures and Characterization Data}

\section{Scheme S1}
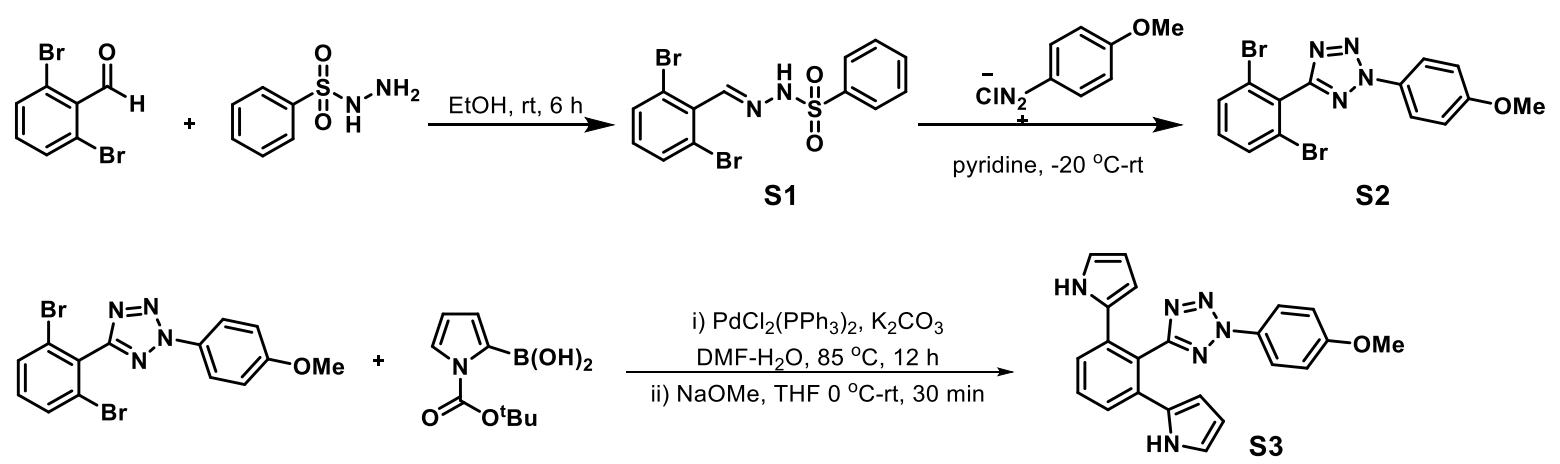

5-(2,6-Di(1H-pyrrol-2-yl)phenyl)-2-(4-methoxyphenyl)-2H-tetrazole (S3): Compound S3 was synthesized by following a reported procedure. ${ }^{1}$ 


\section{Scheme S2}

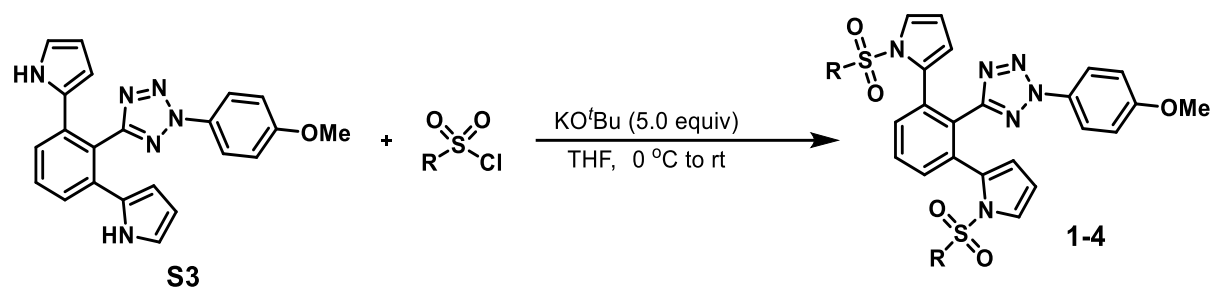

\section{General procedure for the synthesis of $\mathrm{N}$-sulfonated tetrazoles 1-4}

To a solution of $\mathbf{S 3}(100 \mathrm{mg}, 0.26 \mathrm{mmol})$ in dry THF $(10 \mathrm{~mL})$ was added KOtBu $(146 \mathrm{mg}, 1.30 \mathrm{mmol})$ at $0{ }^{\circ} \mathrm{C}$ and the reaction mixture stirred for $15 \mathrm{~min}$. Then respective $\mathrm{RSO}_{2} \mathrm{Cl}$ (5 equiv) was slowly added, and reaction mixture stirred at room temperature for $24 \mathrm{~h}$. After $24 \mathrm{~h}$, another portion of KO'Bu (5 equiv) and sulfonyl chloride ( 5 equiv) were added to the reaction mixture for the completion of starting material. The reaction mixture allowed to stir for another $12-24 \mathrm{~h}$ at room temperature. Then, reaction mixture diluted with water and extracted with EtOAc. The combined organic layers were collected, dried over anhydrous $\mathrm{Na}_{2} \mathrm{SO}_{4}$, filtered, and concentrated under reduced pressure. The residue was purified by flash chromatography using ethyl acetate/hexanes as eluent to afford the desired product.

5-(2,6-Bis(1-(methylsulfonyl)-1H-pyrrol-2-yl)phenyl)-2-(4-methoxyphenyl)-2H-tetrazole (1): Yield: (25 mg, 18\%) Physical appearance: off-white solid. ${ }^{1} \mathrm{H}$ NMR (300 MHz, $\left.\mathrm{CDCl}_{3}\right) \delta 7.82-7.66(\mathrm{~m}, 4 \mathrm{H}), 7.66-7.55$ $(\mathrm{m}, 1 \mathrm{H}), 7.25-7.09(\mathrm{~m}, 2 \mathrm{H}), 7.08-6.89(\mathrm{~m}, 2 \mathrm{H}), 6.45-5.45(\mathrm{~m}, 4 \mathrm{H}), 3.85(\mathrm{~s}, 3 \mathrm{H}), 3.50-2.88(\mathrm{~m}, 6 \mathrm{H}) ;{ }^{13} \mathrm{C}$ $\operatorname{NMR}\left(75 \mathrm{MHz}, \mathrm{CDCl}_{3}\right) \delta 160.52,133.98,132.04,131.95,130.10,127.99,122.76,121.19,116.64,114.70$, 111.66, 55.66, 43.13; HRMS calcd for $\mathrm{C}_{24} \mathrm{H}_{22} \mathrm{~N}_{6} \mathrm{O}_{5} \mathrm{~S}_{2} \mathrm{Na}\left[\mathrm{M}+\mathrm{Na}^{+}\right]$561.0985, found 561.0988.

5-(2,6-Bis(1-(isopropylsulfonyl)-1H-pyrrol-2-yl)phenyl)-2-(4-methoxyphenyl)-2H-tetrazole (2): Yield: (34 mg, 22\%); Physical appearance: white solid. ${ }^{1} \mathrm{H}$ NMR (300 MHz, $\left.\mathrm{CDCl}_{3}\right) \delta 7.81$ (d, $\left.J=9.0 \mathrm{~Hz}, 2 \mathrm{H}\right), 7.69$ (d, $J$ $=7.6 \mathrm{~Hz}, 2 \mathrm{H}), 7.63-7.51(\mathrm{~m}, 1 \mathrm{H}), 7.13(\mathrm{~s}, 2 \mathrm{H}), 6.98(\mathrm{~d}, J=9.0 \mathrm{~Hz}, 2 \mathrm{H}), 6.30-5.88(\mathrm{~m}, 4 \mathrm{H}), 3.85(\mathrm{~s}, 3 \mathrm{H})$, 3.50 (bs, 2H), 1.15 (bs, 12H); ${ }^{13} \mathrm{C}$ NMR $\left(75 \mathrm{MHz}, \mathrm{CDCl}_{3}\right) \delta 160.42,133.77,132.01,131.86,130.17,127.66$, $124.48,121.36,117.08,116.94,114.57,110.28,56.88,55.63,16.36$. HRMS calcd for $\mathrm{C}_{28} \mathrm{H}_{30} \mathrm{~N}_{6} \mathrm{O}_{5} \mathrm{~S}_{2} \mathrm{Na}[\mathrm{M}+$ $\left.\mathrm{Na}^{+}\right], 617.1611$, found 617.1614.

5-(2,6-Bis(1-(cyclopropylsulfonyl)-1H-pyrrol-2-yl)phenyl)-2-(4-methoxyphenyl)-2H-tetrazole (3): Yield: (32 mg, 21\%); Physical appearance: off-white solid. ${ }^{1} \mathrm{H}$ NMR (300 MHz, $\left.\mathrm{CDCl}_{3}\right) \delta 7.82-7.68(\mathrm{~m}, 4 \mathrm{H}), 7.61$ $(t, J=7.6 \mathrm{~Hz}, 1 \mathrm{H}), 7.14(\mathrm{~s}, 2 \mathrm{H}), 6.97(\mathrm{~d}, J=9.0 \mathrm{~Hz}, 2 \mathrm{H}), 6.44-5.67(\mathrm{~m}, 4 \mathrm{H}), 3.85(\mathrm{~s}, 3 \mathrm{H}), 3.00-2.39(\mathrm{~m}, 2 \mathrm{H})$, 
$1.20-0.91(\mathrm{~m}, 8 \mathrm{H}) ;{ }^{13} \mathrm{C}$ NMR $\left(75 \mathrm{MHz}, \mathrm{CDCl}_{3}\right) \delta 160.42,133.77,132.42,131.81,130.20,127.76,123.03$, $121.31,116.55,114.59,110.87,109.25,55.64,32.75,6.82 ; \mathrm{HRMS}$ calcd for $\mathrm{C}_{28} \mathrm{H}_{26} \mathrm{~N}_{6} \mathrm{O}_{5} \mathrm{~S}_{2} \mathrm{Na}\left[\mathrm{M}+\mathrm{Na}^{+}\right]$ 613.1298 found 613.1305 .

5-(2,6-Bis(1-(cyclohexylsulfonyl)-1H-pyrrol-2-yl)phenyl)-2-(4-methoxyphenyl)-2H-tetrazole (4): Yield: (47 mg, 27\%); Physical appearance: off-white solid; ${ }^{1} \mathrm{H}$ NMR (300 MHz, $\left.\mathrm{CDCl}_{3}\right) \delta 7.84-7.73(\mathrm{~m}, 4 \mathrm{H}), 7.61$ $-7.52(\mathrm{~m}, 1 \mathrm{H}), 7.13(\mathrm{~s}, 2 \mathrm{H}), 6.96(\mathrm{~d}, J=9.0 \mathrm{~Hz}, 2 \mathrm{H}), 6.23-5.98(\mathrm{~m}, 4 \mathrm{H}), 4.00-2.78(\mathrm{~m}, 5 \mathrm{H}), 1.84-1.08$ $(\mathrm{m}, 2 \mathrm{H}) ;{ }^{13} \mathrm{C} \mathrm{NMR}\left(75 \mathrm{MHz}, \mathrm{CDCl}_{3}\right) \delta 160.37,160.30,133.64,132.27,132.06,130.26,127.52,125.50$, $124.26,121.72,116.53,114.45,110.20,63.97,55.62,25.45,24.87,24.42 ; \mathrm{HRMS}$ calcd for $\mathrm{C}_{34} \mathrm{H}_{38} \mathrm{~N}_{6} \mathrm{O}_{5} \mathrm{~S}_{2} \mathrm{Na}$ $\left[\mathrm{M}+\mathrm{Na}^{+}\right]$697.2238, found 697.2248.

\section{Scheme S3}

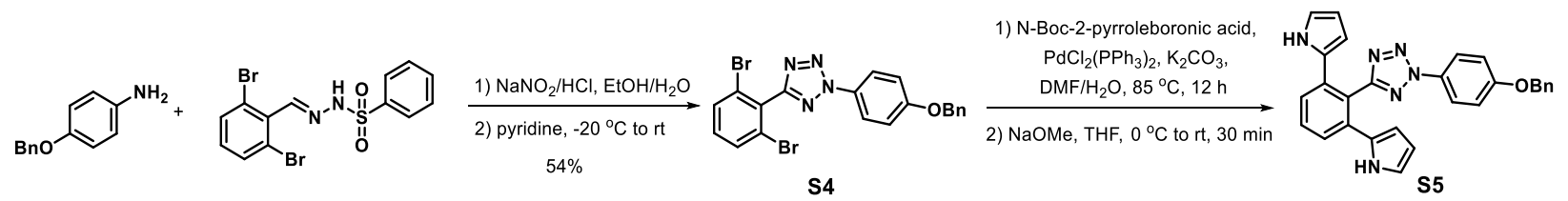

2-(4-(Benzyloxy)phenyl)-5-(2,6-dibromophenyl)-2H-tetrazole (S4): Compound S4 was synthesized by following a literature procedure. ${ }^{1}$ Yield: (1.8 g, 54\%); Physical appearance: yellow solid. ${ }^{1} \mathrm{H}$ NMR (400 MHz, $\left.\mathrm{CDCl}_{3}\right) \delta 8.13(\mathrm{~d}, J=9.0 \mathrm{~Hz}, 2 \mathrm{H}), 7.67(\mathrm{t}, J=8.2 \mathrm{~Hz}, 2 \mathrm{H}), 7.51-7.31(\mathrm{~m}, 5 \mathrm{H}), 7.28-7.06(\mathrm{~m}, 3 \mathrm{H}), 5.15(\mathrm{~s}$, 2H).; ${ }^{13} \mathrm{CNMR}\left(100 \mathrm{MHz}, \mathrm{CDCl}_{3}\right) \delta 163.37,159.83,136.21,132.53,131.94,130.75,130.47,128.73,128.27$, 127.50, 125.39, 121.56, 115.74, 70.41; HRMS calcd for $\mathrm{C}_{20} \mathrm{H}_{15} \mathrm{Br}_{2} \mathrm{~N}_{4} \mathrm{O}\left[\mathrm{M}+\mathrm{H}^{+}\right] 484.9608$ and 486.9587, found 484.9607 and 486.9585 .

2-(4-(Benzyloxy)phenyl)-5-(2,6-di(1H-pyrrol-2-yl)phenyl)-2H-tetrazole (S5): Compound S5 was synthesized by following a literature procedure. ${ }^{1}$ Yield: $(846 \mathrm{mg}, 60 \%)$; Physical appearance: yellow solid. ${ }^{1} \mathrm{H}$ NMR $\left(300 \mathrm{MHz}, \mathrm{CDCl}_{3}\right) \delta 8.55(\mathrm{~s}, 2 \mathrm{H}), 7.91(\mathrm{~d}, J=9.0 \mathrm{~Hz}, 2 \mathrm{H}), 7.60-7.27(\mathrm{~m}, 8 \mathrm{H}), 7.04(\mathrm{~d}, J=9.0 \mathrm{~Hz}$, 2H), $6.72-6.59(\mathrm{~m}, 2 \mathrm{H}), 6.16-5.99(\mathrm{~m}, 4 \mathrm{H}), 5.12(\mathrm{~s}, 2 \mathrm{H}) ;{ }^{13} \mathrm{C} \mathrm{NMR}\left(100 \mathrm{MHz}, \mathrm{CDCl}_{3}\right) \delta$ 164.64, 159.81, $136.12,135.58,130.67,130.39,130.25,128.71,128.27,127.49,127.44,127.31,121.93,121.60,119.03$, 115.59, 109.25, 70.37; HRMS calcd for $\mathrm{C}_{28} \mathrm{H}_{23} \mathrm{~N}_{6} \mathrm{O}\left[\mathrm{M}+\mathrm{H}^{+}\right]$459.1928, found 459.1934. 


\section{Scheme S4}
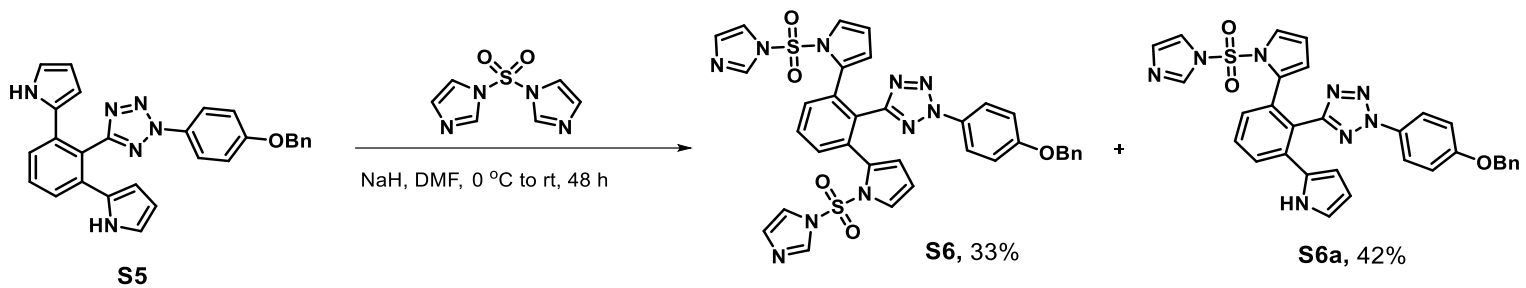

Synthesis of tetrazoles S6 and S6a: To a solution of S5 $(200 \mathrm{mg}, 0.43 \mathrm{mmol})$ in dry DMF (10 mL) was added $\mathrm{NaH}(60 \%, 86 \mathrm{mg}, 2.15 \mathrm{mmol})$ and the reaction mixture was stirred at $0{ }^{\circ} \mathrm{C}$ for $5 \mathrm{~min}$. Then $1,1^{\prime}-$ sulfonyldiimidazole (SDI; $425 \mathrm{mg}, 2.15 \mathrm{mmol}$ ) was slowly added and the reaction mixture was stirred at room temperature for $24 \mathrm{~h}$. Then, another portion of $\mathrm{NaH}$ (2.5 eq) and 1,1'-sulfonyldiimidazole (2.5 eq) were added and the reaction mixture was stirred for another $24 \mathrm{~h}$ to allow the complete consumption of the starting material. The reaction mixture was then concentrated under a reduced pressure. The residue was washed with brine and extracted with ethyl acetate, and the organic layer was separated and concentrated. After evaporating the solvents, the residue was purified by silica gel flash chromatography to obtain compounds $\mathbf{S 6}$ and $\mathbf{S 6 a}$ in $33 \%$ (103 $\mathrm{mg}$ ) and $42 \%$ yield, respectively. Multiple rounds of purification and recrystallization did not yield pure compound S6. Instead, a mixture of compound $\mathbf{S 6}$ and the unreacted 1,1'-sulfonyldiimidazole (2:1) was obtained. This mixture was used directly in the next step.

\section{2-(4-(Benzyloxy)phenyl)-5-(2,6-bis(1-((1H-imidazol-1-yl)sulfonyl)-1H-pyrrol-2-yl)phenyl)-2H-tetrazole}

(S6): Yield: (103 mg, 33\%); Physical appearance: off-white solid; (2:1 mixture of tetrazole S6: SDI). ${ }^{1} \mathrm{H}$ NMR $\left(300 \mathrm{MHz}, \mathrm{CDCl}_{3}\right) \delta 8.03(\mathrm{~s}, 1 \mathrm{H}), 7.87-7.55(\mathrm{~m}, 5 \mathrm{H}), 7.52-7.20(\mathrm{~m}, 10 \mathrm{H}), 7.19-6.73(\mathrm{~m}, 7 \mathrm{H}), 6.42-5.83$ $(\mathrm{m}, 4 \mathrm{H}), 5.11$ (s, 2H); ${ }^{13} \mathrm{C}$ NMR $\left(75 \mathrm{MHz}, \mathrm{CDCl}_{3}\right) \delta 159.53,136.65,136.54,136.18,134.26,133.38,132.43$, $131.08,130.72$, 130.13, 128.67, 128.21, 127.40, 123.03, 121.25, 117.79, 117.62, 117.38, 117.04, 117.01, 115.41, 113.91, 113.06, 70.32; HRMS calcd for $\mathrm{C}_{34} \mathrm{H}_{27} \mathrm{~N}_{10} \mathrm{O}_{5} \mathrm{~S}_{2}\left[\mathrm{M}+\mathrm{H}^{+}\right]$719.1602, found 719.1609.

1,1'-Sulfonylbis(1H-imidazole): ${ }^{1} \mathrm{H}$ NMR (300 MHz, CDCl $) \delta 8.03(\mathrm{~s}, 2 \mathrm{H}), 7.30(\mathrm{~s}, 2 \mathrm{H}), 7.15(\mathrm{~s}, 2 \mathrm{H})$.

\section{5-(2-(1-((1H-Imidazol-1-yl)sulfonyl)-1H-pyrrol-2-yl)-6-(1H-pyrrol-2-yl)phenyl)-2-(4-(benzyloxy)phenyl)-}

2H-tetrazole (S6a): Yield: (108 mg, 42\%); Physical appearance: off-white solid. $\left.{ }^{1} \mathrm{H} \mathrm{NMR} \mathrm{(300} \mathrm{MHz,} \mathrm{CDCl}_{3}\right)$ $\delta 9.03(\mathrm{~s}, 1 \mathrm{H}), 7.87-7.70(\mathrm{~m}, 3 \mathrm{H}), 7.65-7.51(\mathrm{~m}, 2 \mathrm{H}), 7.49-7.29(\mathrm{~m}, 6 \mathrm{H}), 7.26-7.21(\mathrm{~m}, 1 \mathrm{H}), 7.12-6.93$ $(\mathrm{m}, 4 \mathrm{H}), 6.71(\mathrm{~s}, 1 \mathrm{H}), 6.29-5.95(\mathrm{~m}, 4 \mathrm{H}), 5.12(\mathrm{~s}, 2 \mathrm{H}) ;{ }^{13} \mathrm{C} \mathrm{NMR}\left(75 \mathrm{MHz}, \mathrm{CDCl}_{3}\right) \delta 163.25,159.71,136.81$, 136.13, 134.89, 132.65, 131.81, 130.90, 130.84, 130.51, 130.14, 129.99, 129.52, 128.72, 128.28, 127.45, 126.50, 123.10, 121.46, 119.42, 117.77, 117.43, 115.53, 113.07, 109.70, 109.31, 70.36; HRMS calcd for $\mathrm{C}_{31} \mathrm{H}_{24} \mathrm{~N}_{8} \mathrm{O}_{3} \mathrm{SNa}\left[\mathrm{M}+\mathrm{Na}^{+}\right]$611.1584, found 611.1588. 


\section{Scheme S5}

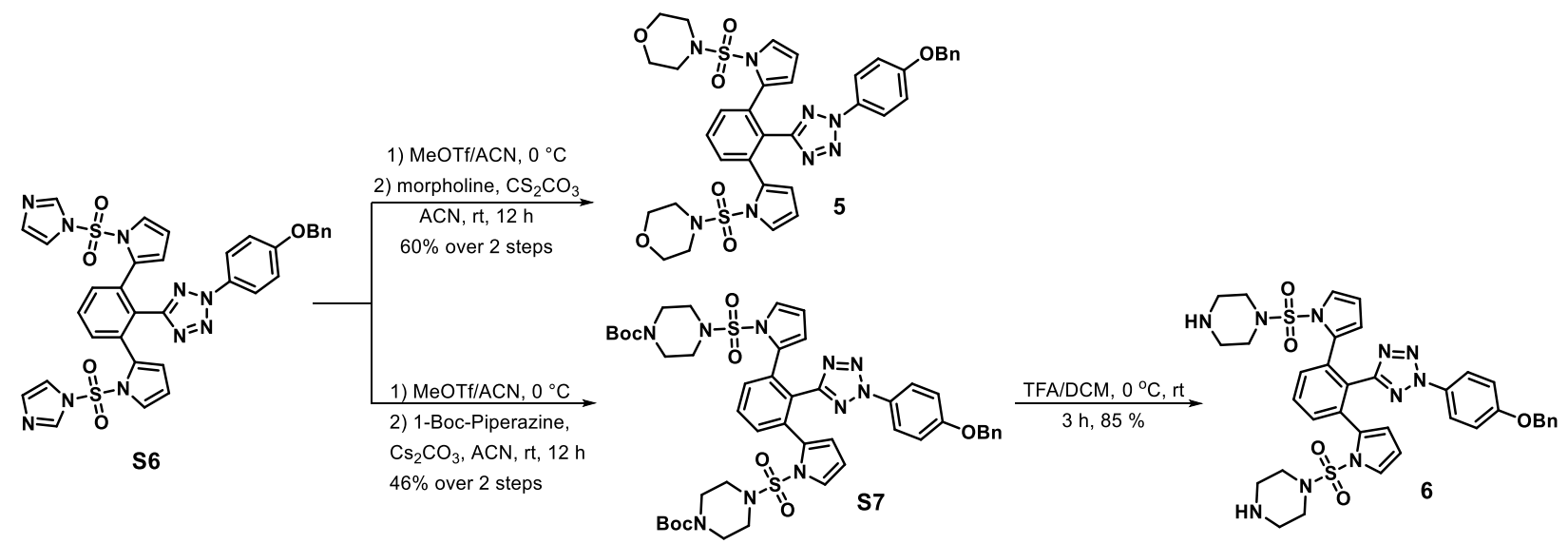

Tetrazoles $\mathbf{5}$ and $\mathbf{S 7}$ were synthesized by following a literature procedure. ${ }^{7}$

2-(4-(Benzyloxy)phenyl)-5-(2,6-bis(1-(morpholinosulfonyl)-1H-pyrrol-2-yl)phenyl)-2H-tetrazole (5):

Step 1: To a solution of $\mathbf{S 6}(40 \mathrm{mg}, 0.055 \mathrm{mmol})$ in dry acetonitrile $(1 \mathrm{~mL})$ was added MeOTf $(45 \mathrm{mg}, 0.27$ $\mathrm{mmol}$ ) at $0{ }^{\circ} \mathrm{C}$ and the reaction mixture was stirred for $4 \mathrm{~h}$. The reaction mixture was then concentrated under reduced pressure. The crude product was used in next step without further purification.

Step 2: To a solution of crude reaction in $A C N$ in dry acetonitrile $(1 \mathrm{~mL})$ was added $\mathrm{Cs}_{2} \mathrm{CO}_{3}(36 \mathrm{mg}, 0.11$ $\mathrm{mmol})$ and morpholine $(23.5 \mathrm{mg}, 0.27 \mathrm{mmol})$ at $0{ }^{\circ} \mathrm{C}$ and the reaction mixture was stirred for $12 \mathrm{~h}$ at room temperature. The reaction mixture was concentrated under reduced pressure. Then, reaction mixture diluted with water and extracted with EtOAc. The combined organic layers were collected, dried over anhydrous $\mathrm{Na}_{2} \mathrm{SO}_{4}$, filtered, and concentrated under reduced pressure. The residue was purified by flash chromatography using ethyl acetate/hexanes as eluent to afford the desired product. Yield: ( $25 \mathrm{mg}, 60$ \%); Physical appearance: off-white solid; ${ }^{1} \mathrm{H}$ NMR (400 MHz, $\left.\mathrm{CDCl}_{3}\right) \delta 7.91$ (d, J = 8.8 Hz, 2H), 7.71 (s, 2H), $7.63-7.52(\mathrm{~m}, 1 \mathrm{H}), 7.50-7.31(\mathrm{~m}, 5 \mathrm{H}), 7.15-6.96(\mathrm{~m}, 4 \mathrm{H}), 6.32-5.68(\mathrm{~m}, 4 \mathrm{H}), 5.12(\mathrm{~s}, 2 \mathrm{H}), 3.60(\mathrm{~s}, 8 \mathrm{H})$, 3.09 (s, 8H); ${ }^{13} \mathrm{C} \mathrm{NMR}\left(100 \mathrm{MHz}, \mathrm{CD}_{3} \mathrm{OD}\right) \delta 163.29,160.05,136.62,133.07,132.48,130.07,129.83,128.23$, $127.75,127.25,123.36,121.17,116.89,115.53,111.03,70.08,43.10,42.63$; HRMS calcd for $\mathrm{C}_{36} \mathrm{H}_{36} \mathrm{~N}_{8} \mathrm{O}_{7} \mathrm{~S}_{2} \mathrm{Na}\left[\mathrm{M}+\mathrm{Na}^{+}\right]$779.2041, found 779.2049.

2-(4-(Benzyloxy)phenyl)-5-(2,6-bis(1-(morpholinosulfonyl)-1H-pyrrol-2-yl)phenyl)-2H-tetrazole

(S7):

Compound S7 was synthesized using same procedure as tetrazole 5. Yield: (27 mg 52\%; Physical appearance: off-white solid. ${ }^{1} \mathrm{H}$ NMR $\left(300 \mathrm{MHz}, \mathrm{CDCl}_{3}\right) \delta 7.86-7.65(\mathrm{~m}, 4 \mathrm{H}), 7.58(\mathrm{t}, J=7.6 \mathrm{~Hz}, 1 \mathrm{H}), 7.48$ - $7.32(\mathrm{~m}, 5 \mathrm{H}), 7.09(\mathrm{~d}, J=8.8 \mathrm{~Hz}, 4 \mathrm{H}), 6.06(\mathrm{~s}, 4 \mathrm{H}), 5.12(\mathrm{~s}, 2 \mathrm{H}), 3.37(\mathrm{~s}, 8 \mathrm{H}), 3.08(\mathrm{~s}, 8 \mathrm{H}), 1.41(\mathrm{~s}, 18 \mathrm{H}) ;{ }^{13} \mathrm{C}$ $\operatorname{NMR}\left(75 \mathrm{MHz}, \mathrm{CDCl}_{3}\right) \delta 159.55,154.23,136.23,133.06,130.35,129.81,128.66,128.19,127.87,127.41$, 
123.64, 121.17, 116.64, 115.73, 110.39, 80.34, 70.33, 45.80, 28.27; HRMS calcd for $\mathrm{C}_{46} \mathrm{H}_{54} \mathrm{~N}_{10} \mathrm{O}{ }_{9} \mathrm{~S}_{2} \mathrm{Na}[\mathrm{M}+$ $\left.\mathrm{Na}^{+}\right]$977.3409, found 977.3413 .

2-(4-(Benzyloxy)phenyl)-5-(2,6-bis(1-(piperazin-1-ylsulfonyl)-1H-pyrrol-2-yl)phenyl)-2H-tetrazole (6): To a solution of $\mathbf{S 7}$ ( $30 \mathrm{mg}, 0.030 \mathrm{mmol}$ ) in DCM (1 mL) was added 2,2,2-trifluoroacetic acid (1 mL), and the mixture was stirred at $0{ }^{\circ} \mathrm{C}$ until all starting materials were consumed. The solvent was removed under reduced pressure and the resulting crude product was treated with diethyl ether to obtain a white precipitate. The precipitate was filtered off, washed with small portions of diethyl ether, and dried under reduced pressure to obtain 6. Yield: (17 mg, 80\%); Physical appearance: off-white solid. ${ }^{1} \mathrm{H}$ NMR ( $400 \mathrm{MHz}$, $\left.\mathrm{CD}_{3} \mathrm{OD}\right) \delta 7.79(\mathrm{~d}, J=8.8 \mathrm{~Hz}, 2 \mathrm{H}), 7.74(\mathrm{~d}, J=7.4 \mathrm{~Hz}, 2 \mathrm{H}), 7.69-7.63(\mathrm{~m}, 1 \mathrm{H}), 7.44(\mathrm{~d}, J=7.2 \mathrm{~Hz}, 2 \mathrm{H}), 7.38$ $(\mathrm{t}, J=7.2 \mathrm{~Hz}, 2 \mathrm{H}), 7.34-7.29(\mathrm{~m}, 1 \mathrm{H}), 7.25-7.11(\mathrm{~m}, 4 \mathrm{H}), 6.39-5.81(\mathrm{~m}, 4 \mathrm{H}), 5.15(\mathrm{~s}, 2 \mathrm{H}), 3.40(\mathrm{~s}, 8 \mathrm{H})$, 3.21 (s, 8H); ${ }^{13} \mathrm{C} \mathrm{NMR}\left(100 \mathrm{MHz}, \mathrm{CD}_{3} \mathrm{OD}\right) \delta 163.29,160.05,136.62,133.07,132.48,130.07,129.83,128.23$, $127.75,127.25,123.36,121.17,116.89,115.53,111.03,70.08,43.10,42.63$; HRMS calcd for $\mathrm{C}_{36} \mathrm{H}_{39} \mathrm{~N}_{10} \mathrm{O}_{5} \mathrm{~S}_{2}$ $\left[\mathrm{M}+\mathrm{H}^{+}\right]$755.2541, found 755.2547.

\section{Scheme S5}
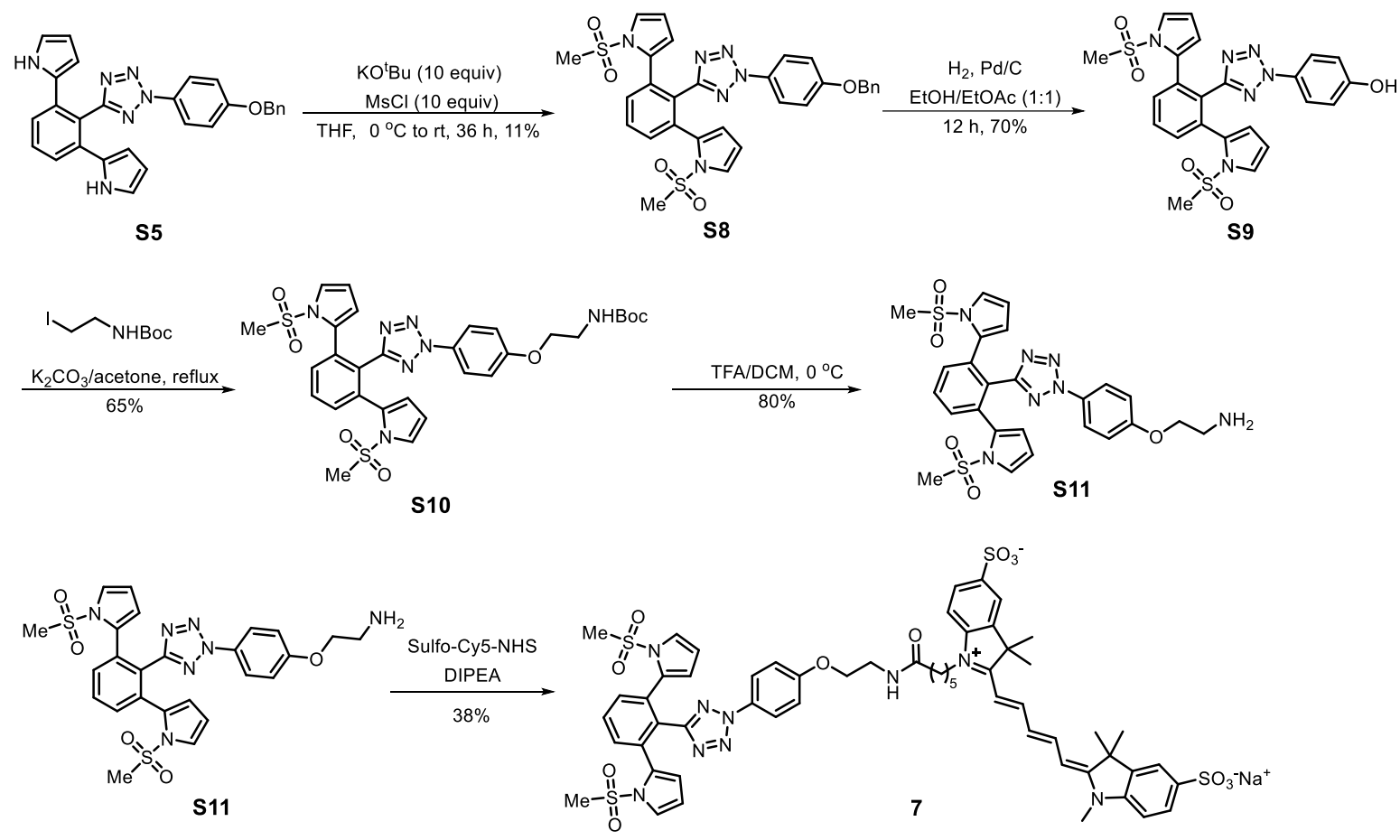

2-(4-(Benzyloxy)phenyl)-5-(2,6-bis(1-(methylsulfonyl)-1H-pyrrol-2-yl)phenyl)-2H-tetrazole (S8): The title compound was prepared using the same procedure as tetrazole 2. Yield: (60 mg, 11\%); Physical appearance: off-white solid. ${ }^{1} \mathrm{H}$ NMR $\left(300 \mathrm{MHz}, \mathrm{CDCl}_{3}\right) \delta 7.79-7.69(\mathrm{~m}, 4 \mathrm{H}), 7.61(\mathrm{t}, \mathrm{J}=7.2 \mathrm{~Hz}, 1 \mathrm{H}), 7.49$ 
- $7.33(\mathrm{~m}, 5 \mathrm{H}), 7.20(\mathrm{~s}, 2 \mathrm{H}), 7.05(\mathrm{~d}, \mathrm{~J}=8.2 \mathrm{~Hz}, 2 \mathrm{H}), 6.35-5.65(\mathrm{~m}, 4 \mathrm{H}), 5.12(\mathrm{~s}, 2 \mathrm{H}), 3.17(\mathrm{~s}, 6 \mathrm{H}) ;{ }^{13} \mathrm{C}$ NMR $\left(75 \mathrm{MHz}, \mathrm{CDCl}_{3}\right) \delta 159.62,136.10,133.95,132.03,131.92,130.24,128.73,128.29,128.01,127.39,122.77$, 121.19, 116.66, 115.64, 111.69, 70.36, 43.14; HRMS calcd for $\mathrm{C}_{30} \mathrm{H}_{27} \mathrm{~N}_{6} \mathrm{O}_{5} \mathrm{~S}_{2}\left[\mathrm{M}+\mathrm{H}^{+}\right] 615.1479$, found 615.1480 .

4-(5-(2,6-Bis(1-(methylsulfonyl)-1H-pyrrol-2-yl)phenyl)-2H-tetrazol-2-yl)phenol (S9): Yield: (35 mg, 70\%); Physical appearance: off-white solid. ${ }^{1} \mathrm{H}$ NMR (300 MHz, $\left.\mathrm{CDCl}_{3}\right) \delta 7.88-7.53(\mathrm{~m}, 5 \mathrm{H}), 7.25-7.11$ $(\mathrm{m}, 2 \mathrm{H}), 6.88(\mathrm{~d}, J=8.8 \mathrm{~Hz}, 2 \mathrm{H}), 6.44(\mathrm{~s}, 1 \mathrm{H}), 6.28-5.58(\mathrm{~m}, 4 \mathrm{H}), 3.09(\mathrm{~s}, 6 \mathrm{H}) ;{ }^{13} \mathrm{C} \mathrm{NMR}\left(75 \mathrm{MHz}, \mathrm{CDCl}_{3}\right) \delta$ 157.44, 133.87, 132.09, 131.92, 129.81, 128.13, 122.79, 121.58, 121.42, 116.76, 116.28, 111.84, 43.15; HRMS calcd for $\mathrm{C}_{23} \mathrm{H}_{21} \mathrm{~N}_{6} \mathrm{O}_{5} \mathrm{~S}_{2}\left[\mathrm{M}+\mathrm{H}^{+}\right]$525.1009, found 525.1010.

tert-Butyl (2-(4-(5-(2,6-bis(1-(methylsulfonyl)-1H-pyrrol-2-yl)phenyl)-2H-tetrazol-2-yl)phenoxy)ethyl) carbamate (S10): The compound $\mathbf{S 1 0}$ synthesized by using literature procedure as an off-white solid (25 $\mathrm{mg}, 65 \%) ;{ }^{1} \mathrm{H}$ NMR $\left(400 \mathrm{MHz}, \mathrm{CDCl}_{3}\right) \delta 7.77-7.69(\mathrm{~m}, 4 \mathrm{H}), 7.60(\mathrm{t}, J=8.0 \mathrm{~Hz}, 1 \mathrm{H}), 7.19(\mathrm{~s}, 2 \mathrm{H}), 6.97(\mathrm{~d}, J$ $=8.8 \mathrm{~Hz}, 2 \mathrm{H}), 6.30-5.80(\mathrm{~m}, 4 \mathrm{H}), 4.96(\mathrm{~s}, 1 \mathrm{H}), 4.06(\mathrm{t}, \mathrm{J}=4.2 \mathrm{~Hz}, 2 \mathrm{H}), 3.61-3.50(\mathrm{~m}, 2 \mathrm{H}), 3.16(\mathrm{~s}, 6 \mathrm{H})$, 1.46 (s, 9H); ${ }^{13} \mathrm{C}$ NMR $\left(100 \mathrm{MHz}, \mathrm{CDCl}_{3}\right) \delta 159.56,155.86,133.99,132.11,131.98,130.41,128.05,122.78$, $121.28,116.66,115.27,111.67,79.77,67.67,43.15,28.39$; HRMS calcd for $\mathrm{C}_{30} \mathrm{H}_{34} \mathrm{~N}_{7} \mathrm{O}_{7} \mathrm{~S}_{2}\left[\mathrm{M}+\mathrm{H}^{+}\right]$ 668.1956, found 668.1957.

2-(4-(5-(2,6-Bis(1-(methylsulfonyl)-1H-pyrrol-2-yl)phenyl)-2H-tetrazol-2-yl)phenoxy)ethan-1-amine

(S11): The title compound was prepared using a similar procedure as tetrazole 6. Yield: (13 mg, 70\%); Physical appearance: off-white solid. ${ }^{1} \mathrm{H}$ NMR (500 MHz, CD $\left.{ }_{3} \mathrm{OD}\right) \delta 7.80$ (d, $\left.J=9.0 \mathrm{~Hz}, 2 \mathrm{H}\right), 7.68(\mathrm{t}, J=7.2$ $\mathrm{Hz}, 2 \mathrm{H}), 7.64-7.58(\mathrm{~m}, 1 \mathrm{H}), 7.22-7.12(\mathrm{~m}, 4 \mathrm{H}), 6.26-5.75(\mathrm{~m}, 4 \mathrm{H}), 4.29(\mathrm{~d}, J=5.0 \mathrm{~Hz}, 2 \mathrm{H}), 3.40(\mathrm{~d}, J=$ $5.0 \mathrm{~Hz}, 2 \mathrm{H}), 3.12(\mathrm{~s}, 6 \mathrm{H}) ;{ }^{13} \mathrm{C}$ NMR $\left(126 \mathrm{MHz}, \mathrm{CD}_{3} \mathrm{OD}\right) \delta$ 159.07, 133.40, 132.47, 131.89, 130.69, 127.87, $127.29,122.50,121.13,116.21,115.27,111.08,64.38,42.08,38.76$. HRMS calcd for $\mathrm{C}_{25} \mathrm{H}_{26} \mathrm{~N}_{7} \mathrm{O}_{5} \mathrm{~S}_{2}\left[\mathrm{M}+\mathrm{H}^{+}\right]$ 568.1431 , found 568.1426 .

Sodium 1-(6-((2-(4-(5-(2,6-bis(1-(methylsulfonyl)-1H-pyrrol-2-yl)phenyl)-2H-tetrazol-2-yl)phenoxy) ethyl)amino)-6-oxohexyl)-3,3-dimethyl-2-((1E,3E)-5-((E)-1,3,3-trimethyl-5-sulfonatoindolin-2-ylidene) penta-1,3-dien-1-yl)-3H-indol-1-ium-5-sulfonate (7): To a solution of S11 (2.15 mg, $0.0026 \mathrm{mmol})$ in 500 $\mu \mathrm{L}$ DMF were added DIPEA $(2 \mu \mathrm{L}, 0.0078 \mathrm{mmol})$ and sulfo-Cy5-NHS ester $(2.0 \mathrm{mg}, 0.0026 \mathrm{mmol})$. The mixture was stirred at room temperature overnight. It was then concentrated to dryness and the residue was purified by reverse-phase HPLC using acetonitrile/ $\mathrm{H}_{2} \mathrm{O}$ as eluent to give the titled compound (38\% 
yield). The identity and purity of desired compound was verified by ESI-LCMS and HPLC, respectively. HRMS calcd for $\mathrm{C}_{57} \mathrm{H}_{61} \mathrm{~N}_{9} \mathrm{O}_{12} \mathrm{~S}_{4}\left[\mathrm{M}+\mathrm{H}^{+}\right]$1192.3395, found 1192.3387 .

\section{Synthesis of $N^{6}-((((1 R, 8 S, 9 S)-$ bicyclo[6.1.0]non-4-yn-9-yl)methoxy)carbonyl)-L-lysine (BCNK):}

\section{Scheme S6}
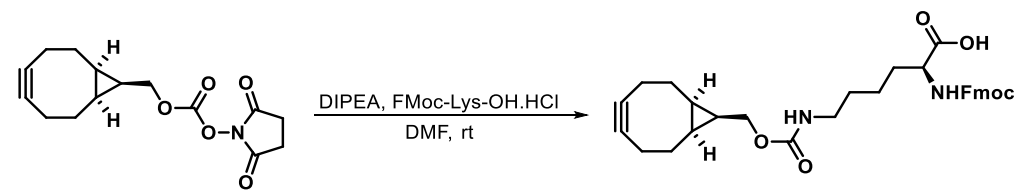

DIEA, DCM, rt, $8 \mathrm{~h}$

$56 \%$ yield over 2 steps

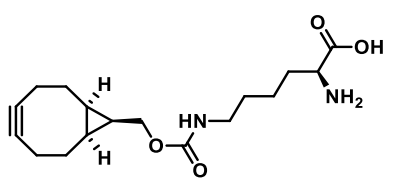

BCNK was synthesized as an off-white solid ( $31 \mathrm{mg}, 56 \%)$ by following a reported procedure. ${ }^{8}$

\section{HEK293T Cell Culture and Transfection}

HEK293T cells were maintained in growth medium containing Dulbecco's modified eagle medium (DMEM, Life Technologies) supplemented with $10 \%(\mathrm{v} / \mathrm{v}$ ) fetal bovine serum (FBS, Life Technologies) and $10 \mu \mathrm{g} / \mathrm{mL}$ Gentamicin (Life Technologies). Transfection was performed at $70-80 \%$ confluency using 3:1 reagent: DNA ratio of Lipofectamine 2000 (Life Technologies) with $2.5 \mu \mathrm{g}$ of total DNA or polyethylenimine (PEI, Polysciences, Inc.) with $3 \mu \mathrm{g}$ of total DNA per $35 \mathrm{~mm}$ dish. For imaging experiments, cells were kept in imaging medium (FluoroBrite DMEM supplemented with 10\% FBS, 4 mM L-glutamine, and 25 mM HEPES).

\section{Bioorthogonal Labeling of BCNK-Encoded GCGR-GFP and Confocal Microscopy}

Bioorthogonal Labeling of BCNK-Encoded GCGR-GFP was performed using similar protocol published in the literature. ${ }^{1,9}$ HEK 293T cells were cotransfected with a 2:1 ratio of BCN-tRNA synthetase (BCNRS) ${ }^{10}$ and pCMV-GCGRH372TAG-GFP plasmids. For BocK incorporation, HEK 293T cells were cotransfected with a 4:1 ratio of pCMV-MmPyIRS-U6-tRNA and pCMV-GCGRH372TAG-GFP plasmids. A solution of $20 \mathrm{mM}$ BCNK in DMSO was diluted in growth medium to obtain a final concentration of $200 \mu \mathrm{M} \mathrm{BCNK}$, and the resulting medium was filtered through $0.2 \mu \mathrm{m}$ poly(ether sulfone) membrane. For Bock, a final concentration of $1 \mathrm{mM}$ in growth medium was used. The medium was added to the cells followed by the transfection mixture. The cells were incubated for an additional $24-48 \mathrm{~h}$ and then washed with the growth medium prior to labeling. A fresh solution of tetrazole 7 was prepared from $1 \mathrm{mM}$ stock solution in DMSO to a final concentration of $200 \mathrm{nM}$ and in $1 \mathrm{~mL}$ of growth medium. The solution was added to HEK293T cells expressing BocK or BCNK-encoded GCGR and the culture was exposed to $302 \mathrm{~nm}$ UV light for a brief period ( $15 \mathrm{~s}, 30 \mathrm{~s}$ and or $60 \mathrm{~s})$. The tetrazole-containing medium was removed, and the cells were washed 
with growth medium before incubation in $1 \mathrm{~mL}$ of growth medium at $37^{\circ} \mathrm{C}$ and $5 \% \mathrm{CO}_{2}$ for an additional $30 \mathrm{~min}$. The medium was then switched to FluoroBrite DMEM before laser scanning confocal microscopy. The confocal images were acquired using a Zeiss LSM 710 equipped with Plan-Apochromat 20×/0.8 M27 or 40x/1.3 Oil DIC M27 objective with ex. 488/em. 493-598 nm for the GFP channel and ex. 640/em. 645 $-759 \mathrm{~nm}$ for the Cy5 channel.

\section{Computational Details}

Calculations were carried out with the Gaussian16 program package. ${ }^{11}$ Geometry optimizations were performed with the B3LYP/6-31+G(d) level of theory including Grimme's DFT-D3 dispersion correction ${ }^{12}$ and the SMD implicit solvation model using the dielectric constant of water. ${ }^{13}$ Single-point energy calculations and frequency analysis on the B3LYP-D3-optimized geometries were performed with the $\omega B 97 X-D / 6-311++G(d, p)$ level of theory and the SMD solvation model with water as the solvent. Transition states were determined using the QST3 method implemented in Gaussian16. Frequency calculations confirmed the nature of the minima for the reactant complexes and products, and the nature of saddle points, with only one imaginary frequency, for the transition states. $\Delta \mathrm{G}$ and $\Delta \mathrm{G}^{\ddagger}$ were calculated at $298 \mathrm{~K}$ from the frequency analysis results. Cartesian coordinates for the reactant complexes (R) (both end-on and side-on), transition states (TS), and products (P) are reported in the Cartesian Coordinates section.

\section{References}

(1) An, P.; Lewandowski, T. M.; Erbay, T. G.; Liu, P.; Lin, Q. Sterically Shielded, Stabilized Nitrile Imine for Rapid Bioorthogonal Protein Labeling in Live Cells. J. Am. Chem. Soc. 2018, 140, 4860-4868.

(2) Jiang, S.; Wu, X.; Liu, H.; Deng, J.; Zhang, X.; Yao, Z.; Zheng, Y.; Li, B.; Yu, Z. Ring-Strain-Promoted Ultrafast Diaryltetrazole-Alkyne Photoclick Reactions Triggered by Visible Light. Chemphotochem 2020, 4, 327-331.

(3) Alamudi, S. H.; Satapathy, R.; Kim, J.; Su, D.; Ren, H.; Das, R.; Hu, L.; Alvarado-Martínez, E.; Lee, J. Y.; Hoppmann, C.; Peña-Cabrera, E.; Ha, H.-H.; Park, H.-S.; Wang, L.; Chang, Y.-T. Development of backgroundfree tame fluorescent probes for intracellular live cell imaging. Nature Communications 2016, 7, 11964.

(4) McGarry, D. J.; Shchepinova, M. M.; Lilla, S.; Hartley, R. C.; Olson, M. F. A Cell-Permeable Biscyclooctyne As a Novel Probe for the Identification of Protein Sulfenic Acids. ACS Chem. Biol. 2016, 11, 3300-3304.

(5) An, P.; Yu, Z.; Lin, Q. Design of oligothiophene-based tetrazoles for laser-triggered photoclick chemistry in living cells. Chem Commun (Camb) 2013, 49, 9920-9922.

(6) Yu, Z. P.; Lin, Q. Design of Spiro[2.3]hex-1-ene, a Genetically Encodable Double-Strained Alkene for Superfast Photoclick Chemistry. J. Am. Chem. Soc. 2014, 136, 4153-4156.

(7) Qrareya, H.; Protti, S.; Fagnoni, M. Aryl Imidazylates and Aryl Sulfates As Electrophiles in Metal-Free ArSN1 Reactions. J. Org. Chem 2014, 79, 11527-11533. 
(8) Lang, K.; Davis, L.; Wallace, S.; Mahesh, M.; Cox, D. J.; Blackman, M. L.; Fox, J. M.; Chin, J. W. Genetic Encoding of bicyclononynes and trans-cyclooctenes for site-specific protein labeling in vitro and in live mammalian cells via rapid fluorogenic Diels-Alder reactions. J Am Chem Soc 2012, 134, 10317-10320.

(9) Gangam, S. K.; Lin, Q. Fluorescent bioorthogonal labeling of class B GPCRs in live cells. Methods Enzymol. 2020, 641, 95-111.

(10) Peng, T.; Hang, H. C. Site-Specific Bioorthogonal Labeling for Fluorescence Imaging of Intracellular Proteins in Living Cells. J. Am. Chem. Soc. 2016, 138, 14423-14433.

(11) Frisch, M. J.; Trucks, G. W.; Schlegel, H. B.; Scuseria, G. E.; Robb, M. A.; Cheeseman, J. R.; Scalmani, G.; Barone, V.; Petersson, G. A.; Nakatsuji, H.; Li, X.; M, C.; Marenich, A. V.; Bloino, J.; Janesko, B. G.; Gomperts, R.; Mennucci, B.; Hratchian, H. P.; Ortiz, J. V.; Izmaylov, A. F.; Sonnenberg, J. L.; Williams-Young, D.; Ding, F.; Lipparini, F.; Egidi, F.; Goings, J.; Peng, B.; Petrone, A.; Henderson, T.; Ranasinghe, D.; Zakrzewski, V. G.; Gao, J.; Rega, N.; Zheng, G.; Liang, W.; Hada, M.; Ehara, M.; Toyota, K.; Fukuda, R.; Hasegawa, J.; Ishida, M.; Nakajima, T.; Honda, Y.; Kitao, O.; H. Nakai; Vreven, T.; Throssell, K.; J. A. Montgomery, J.; Peralta, J. E.; Ogliaro, F.; Bearpark, M. J.; Heyd, J. J.; Brothers, E. N.; Kudin, K. N.; Staroverov, V. N.; Keith, T. A.; Kobayashi, R.; Normand, J.; Raghavachari, K.; Rendell, A. P.; Burant, J. C.; Iyengar, S. S.; Tomasi, J.; Cossi, M.; Millam, J. M.; Klene, M.; Adamo, C.; Cammi, R.; Ochterski, J. W.; Martin, R. L.; Morokuma, K.; Farkas, O.; Foresman, J. B.; Fox, D. J. Gaussian 16, Revision B.01, Gaussian, Inc., Wallingford, CT.: 2016.

(12) Grimme, S.; Antony, J.; Ehrlich, S.; Krieg, H. A consistent and accurate ab initio parameterization of density functional dispersion correction (DFT-D) for the 94 elements H-Pu. J Chem Phys 2010, 132, 154104.

(13) Marenich, A. V.; Cramer, C. J.; Truhlar, D. G. Universal Solvation Model Based on Solute Electron Density and on a Continuum Model of the Solvent Defined by the Bulk Dielectric Constant and Atomic Surface Tensions. J Phys Chem B 2009, 113, 6378-6396. 
${ }^{1} \mathrm{H}$ and ${ }^{13} \mathrm{C}$ NMR Spectra

\begin{tabular}{|c|c|}
\hline 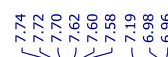 & 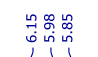 \\
\hline
\end{tabular}
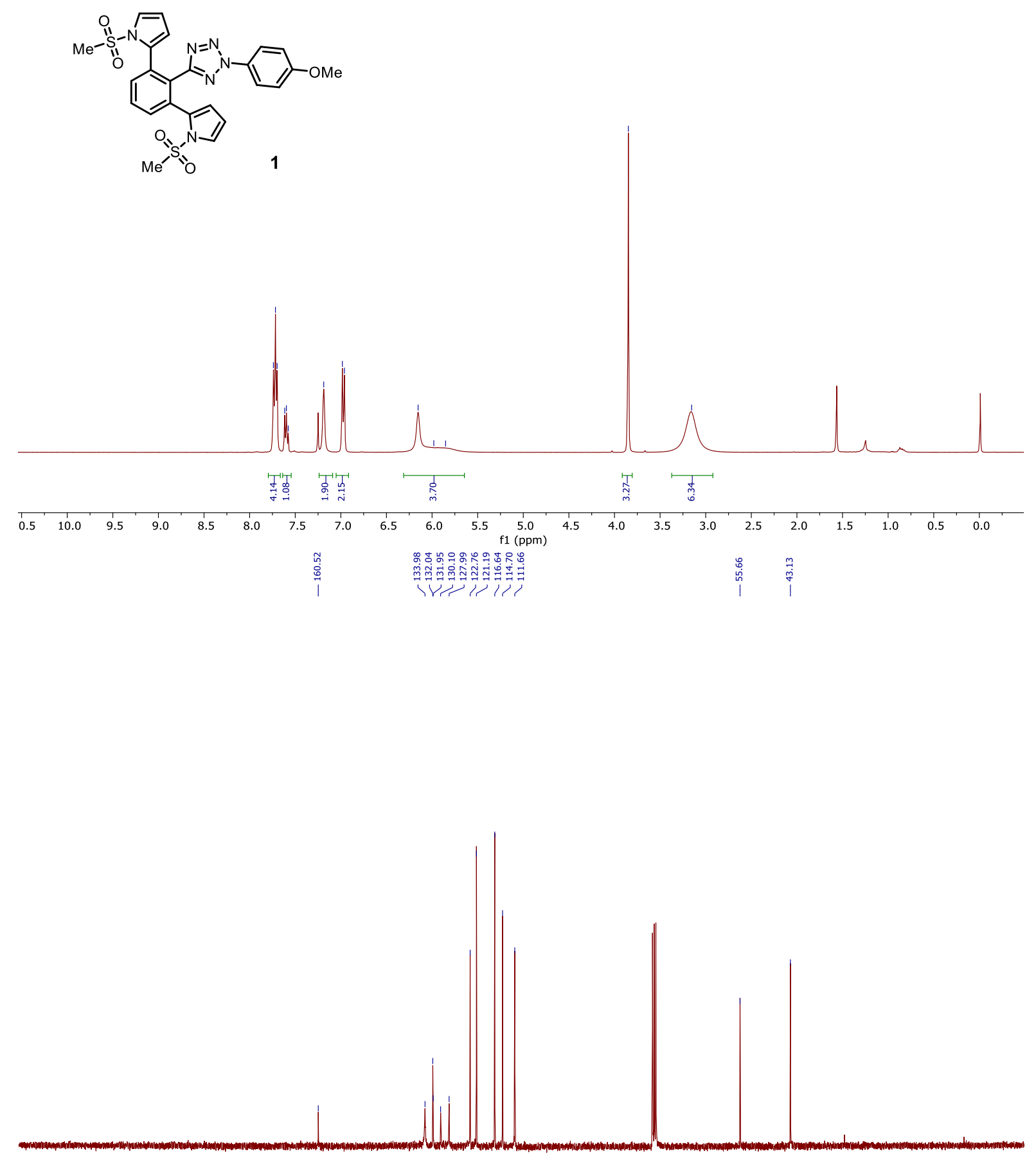

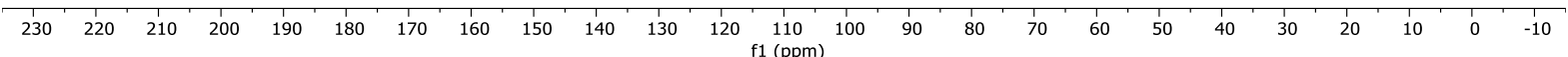




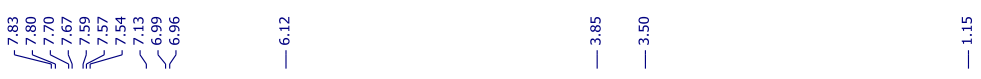
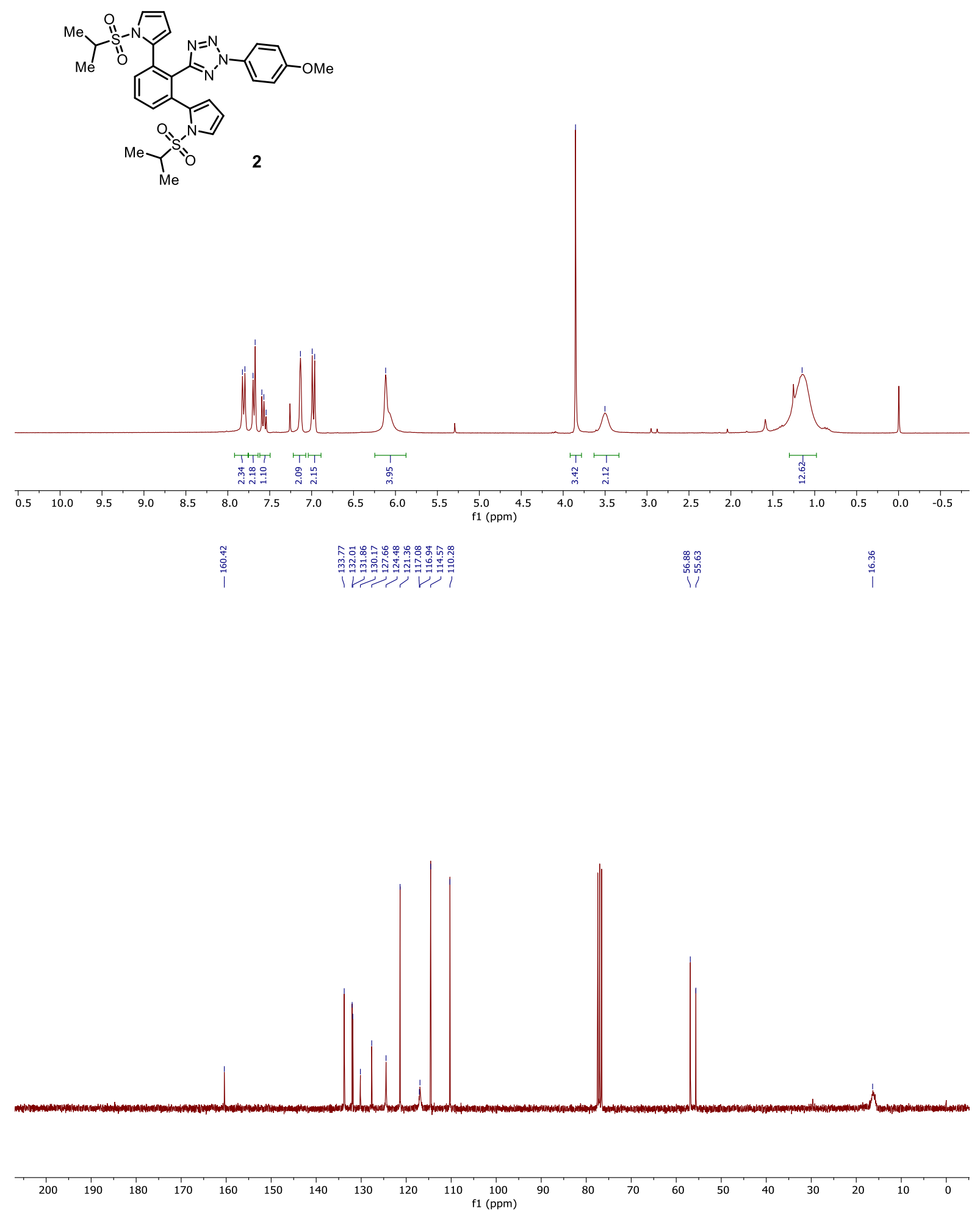


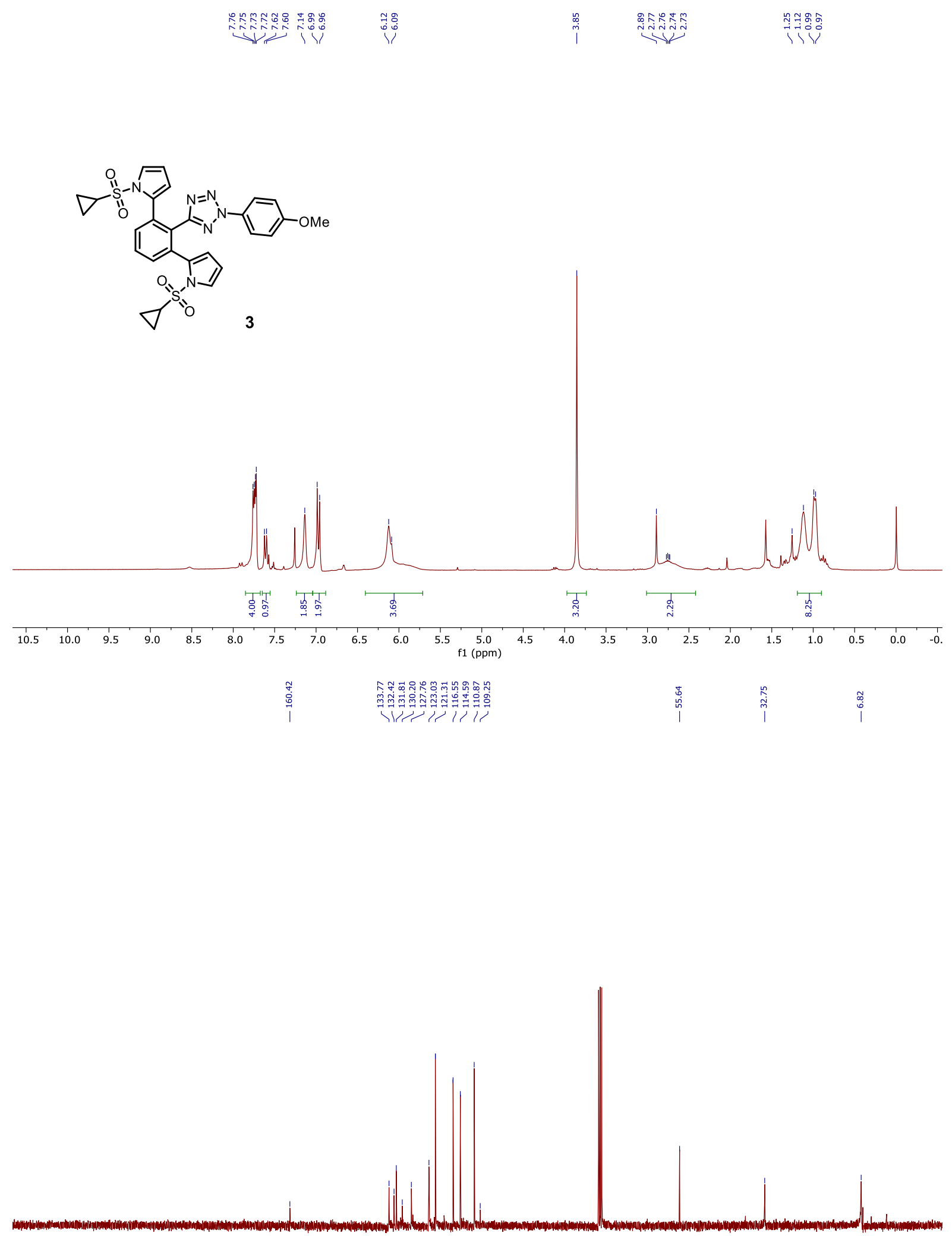

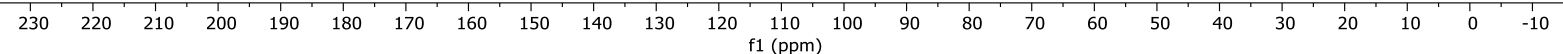



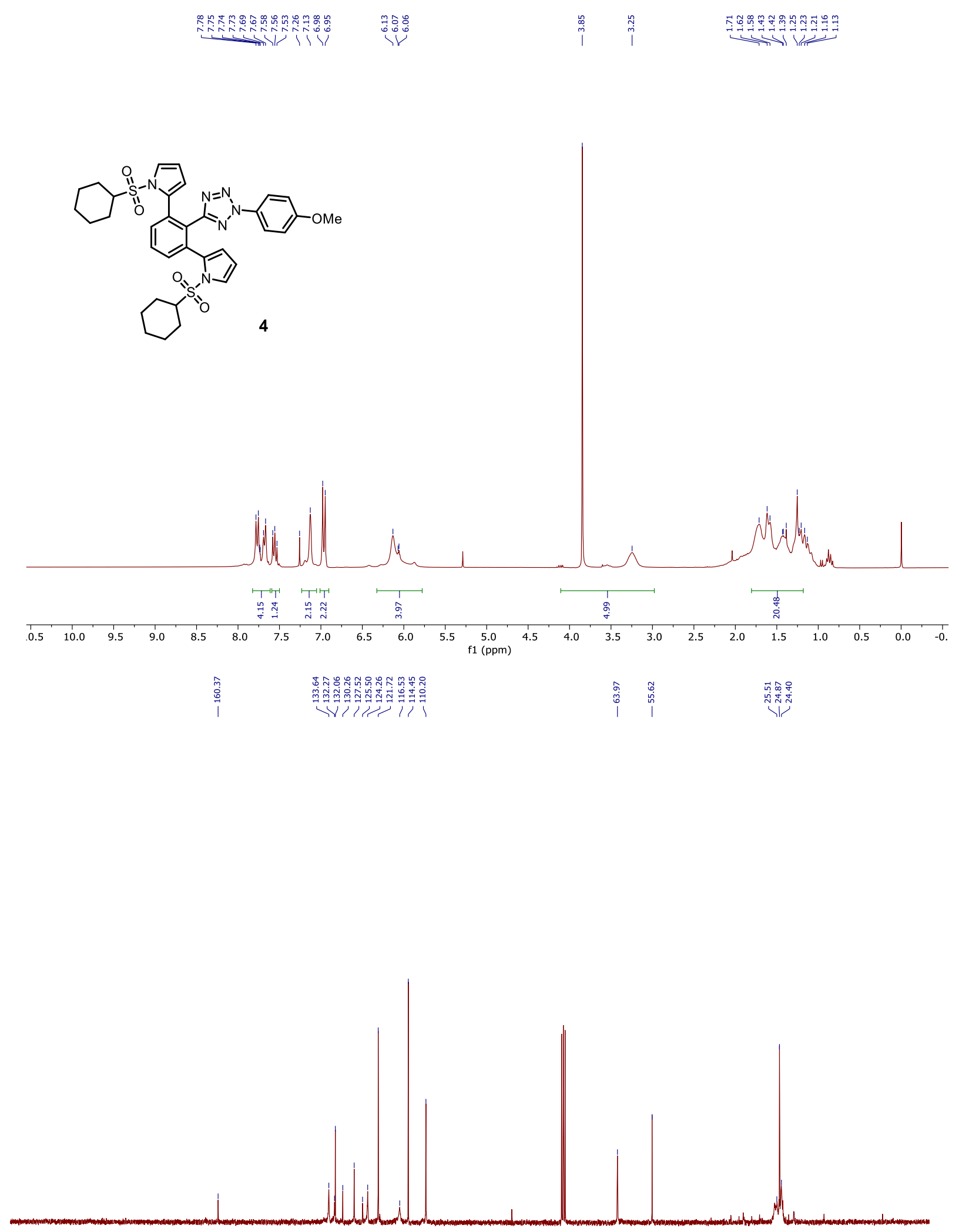

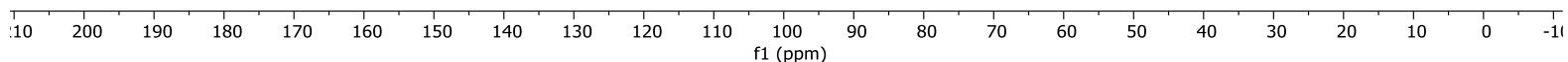




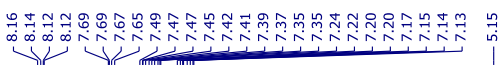
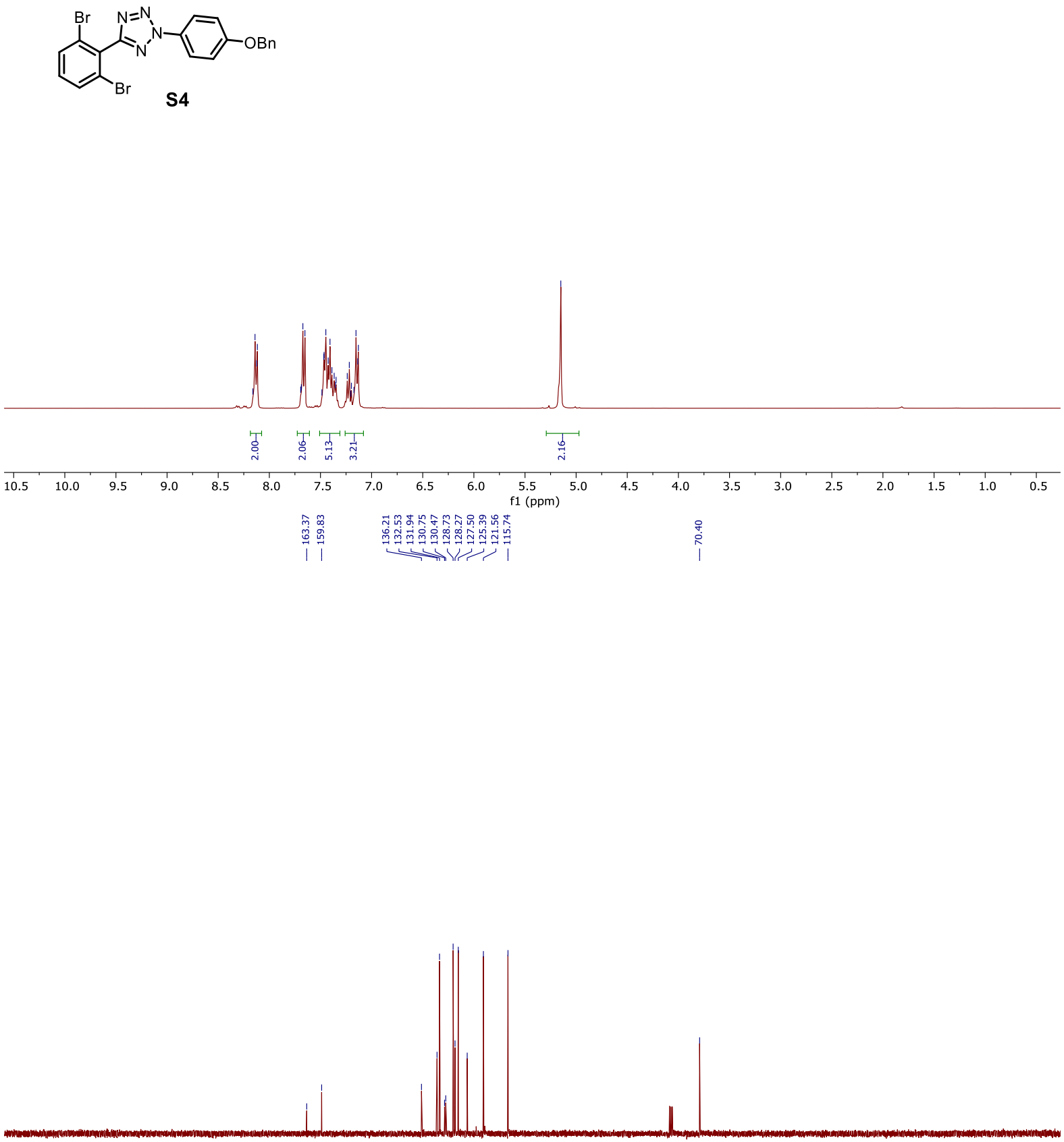

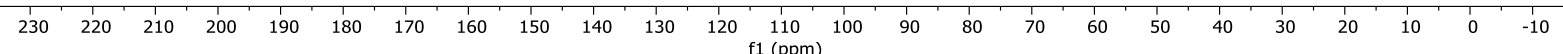



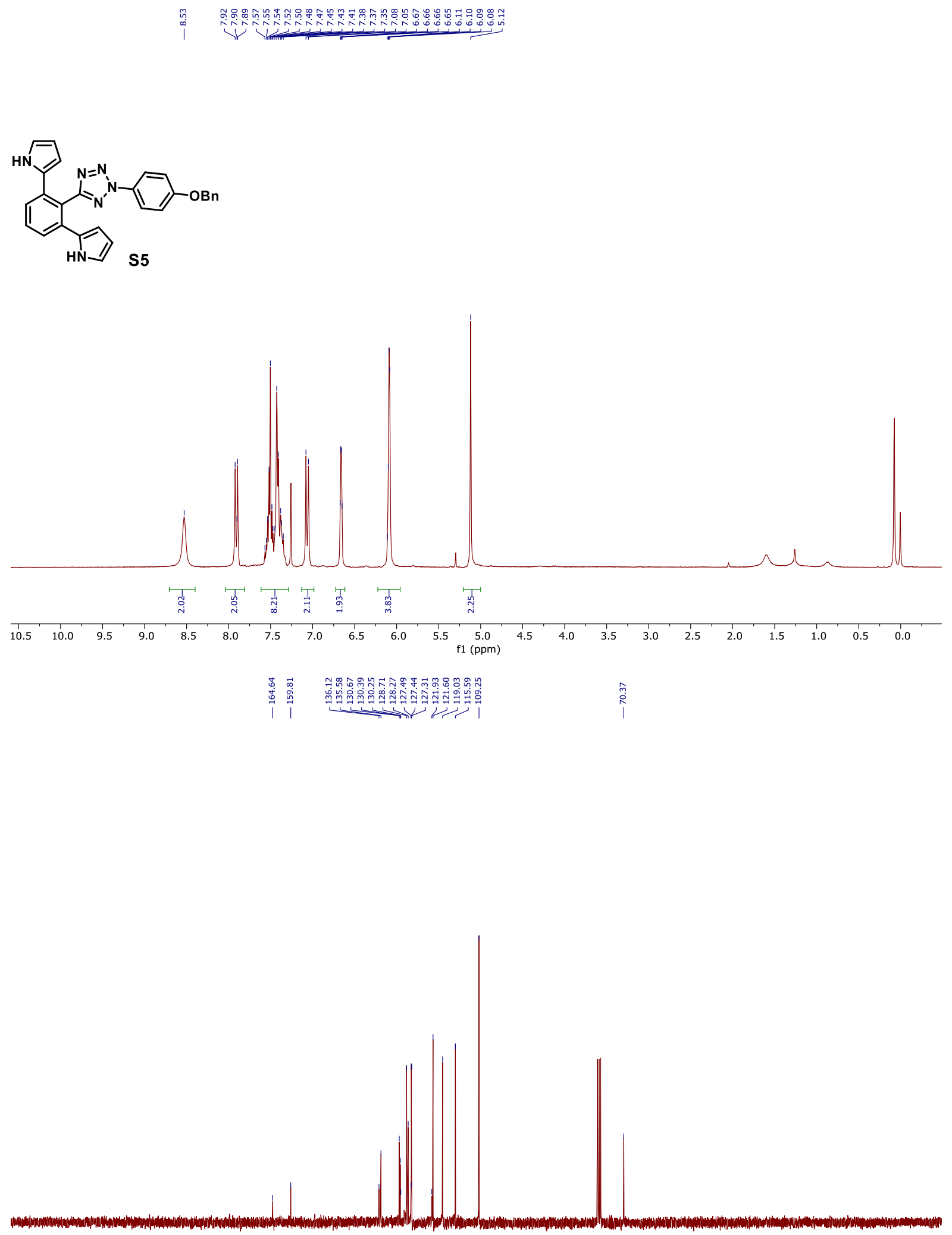

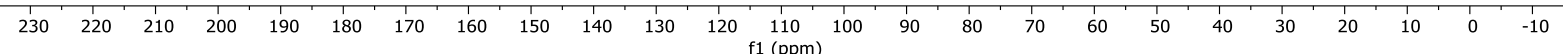



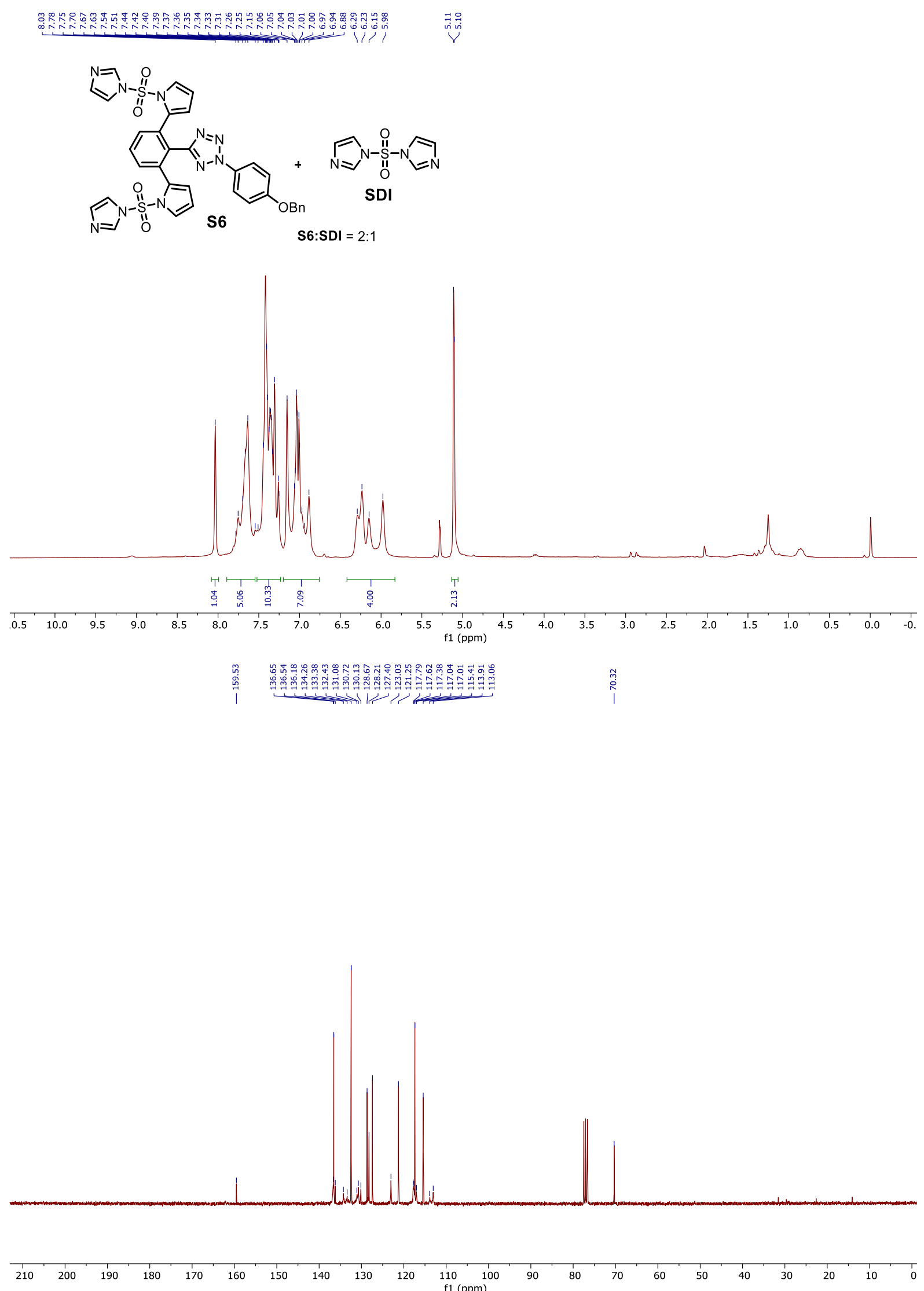

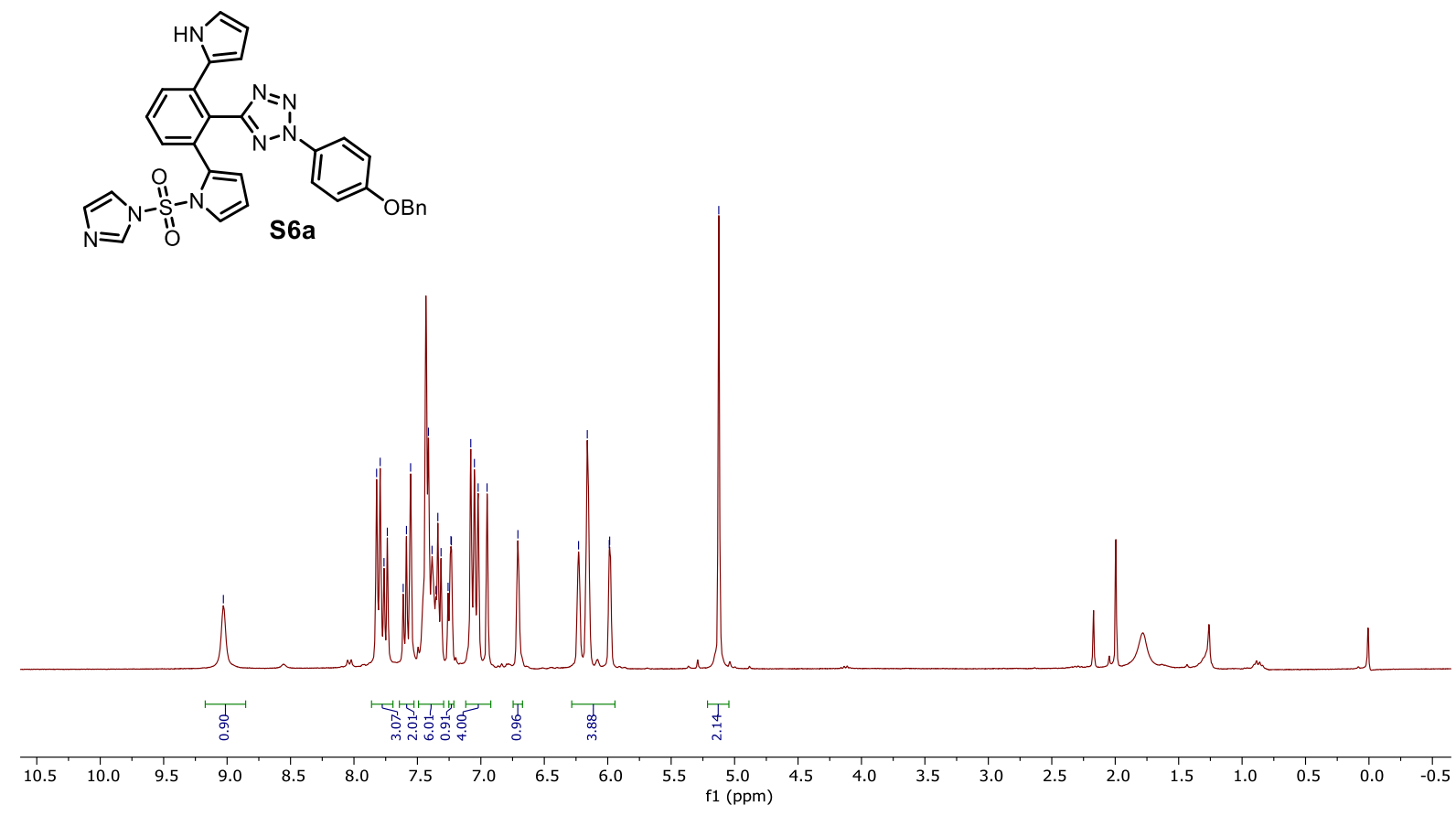

L

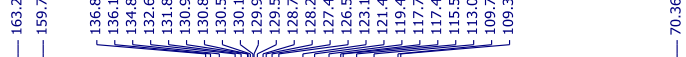

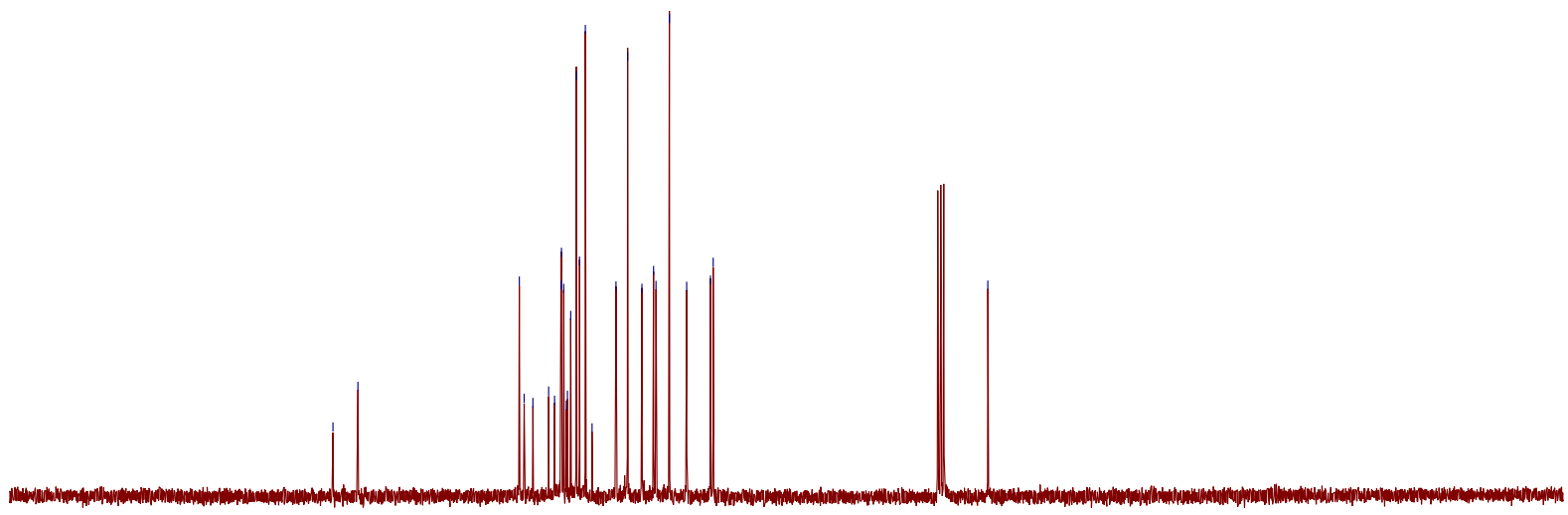

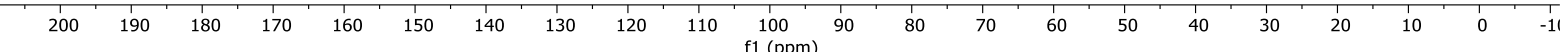




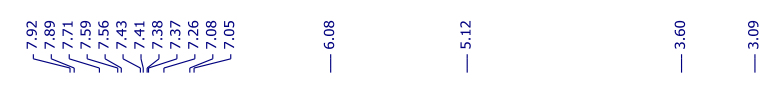
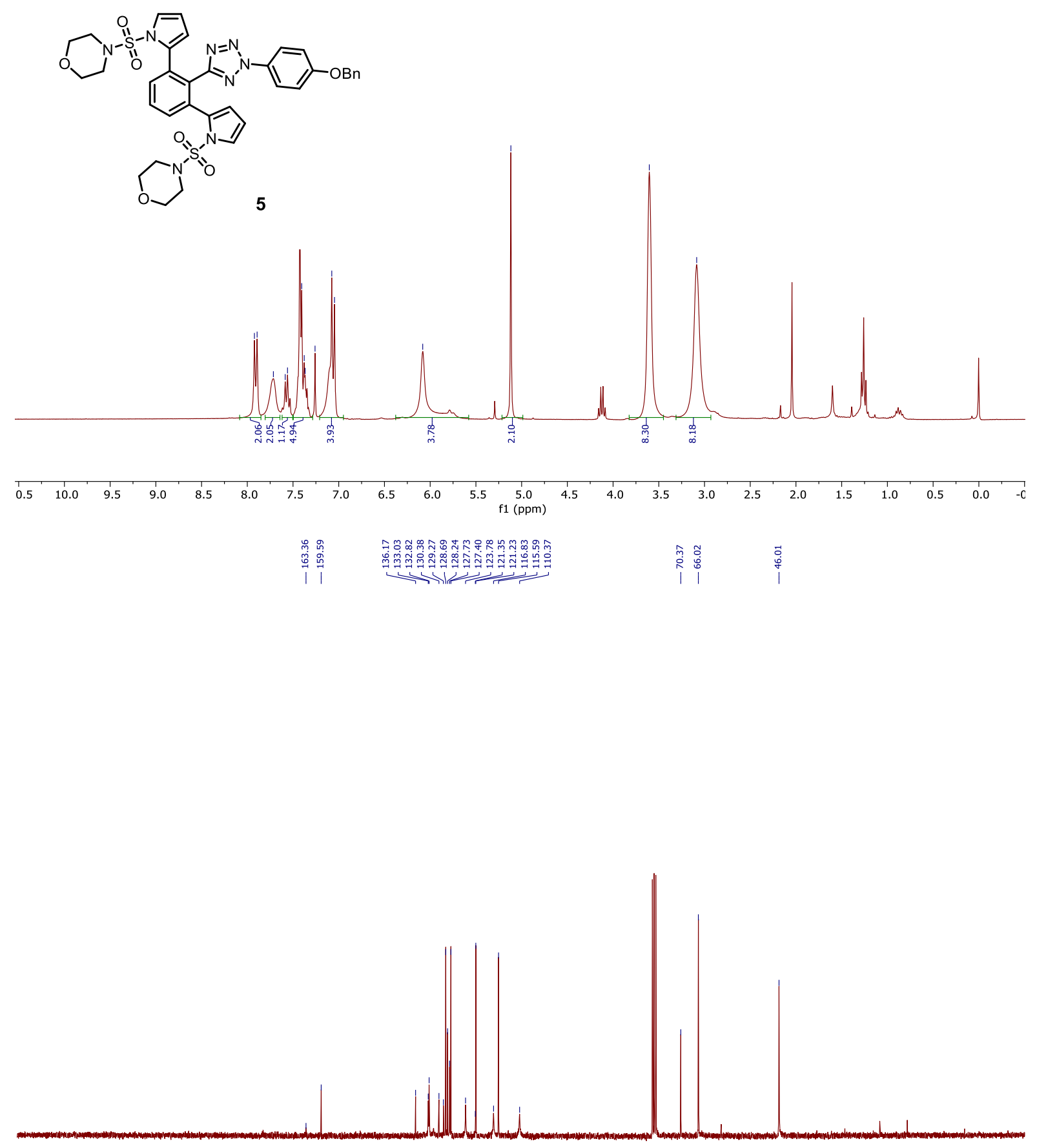

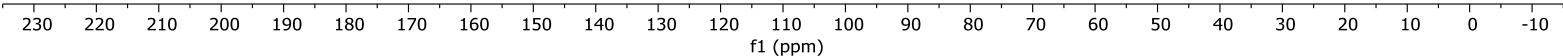



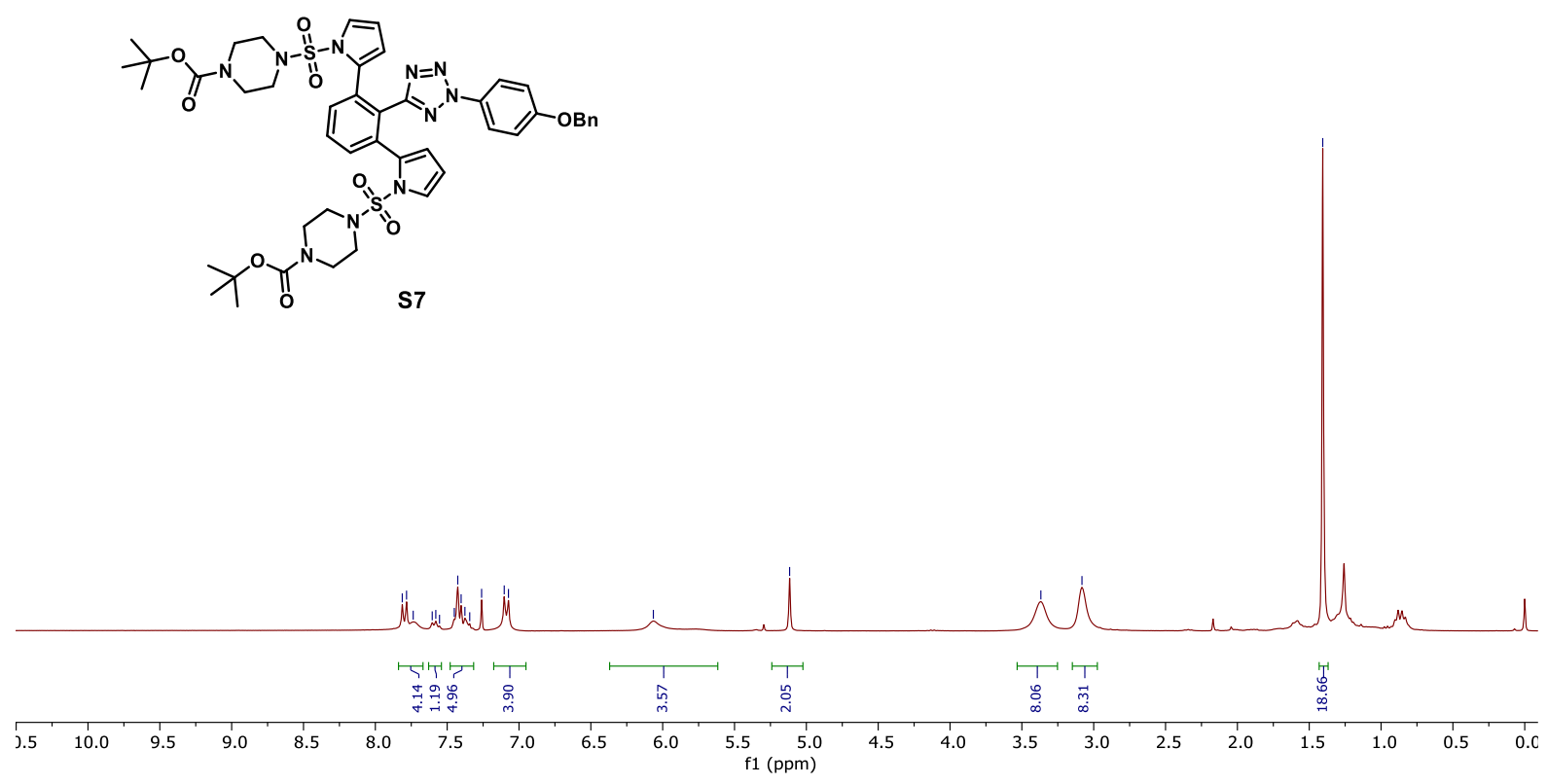

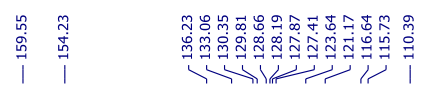
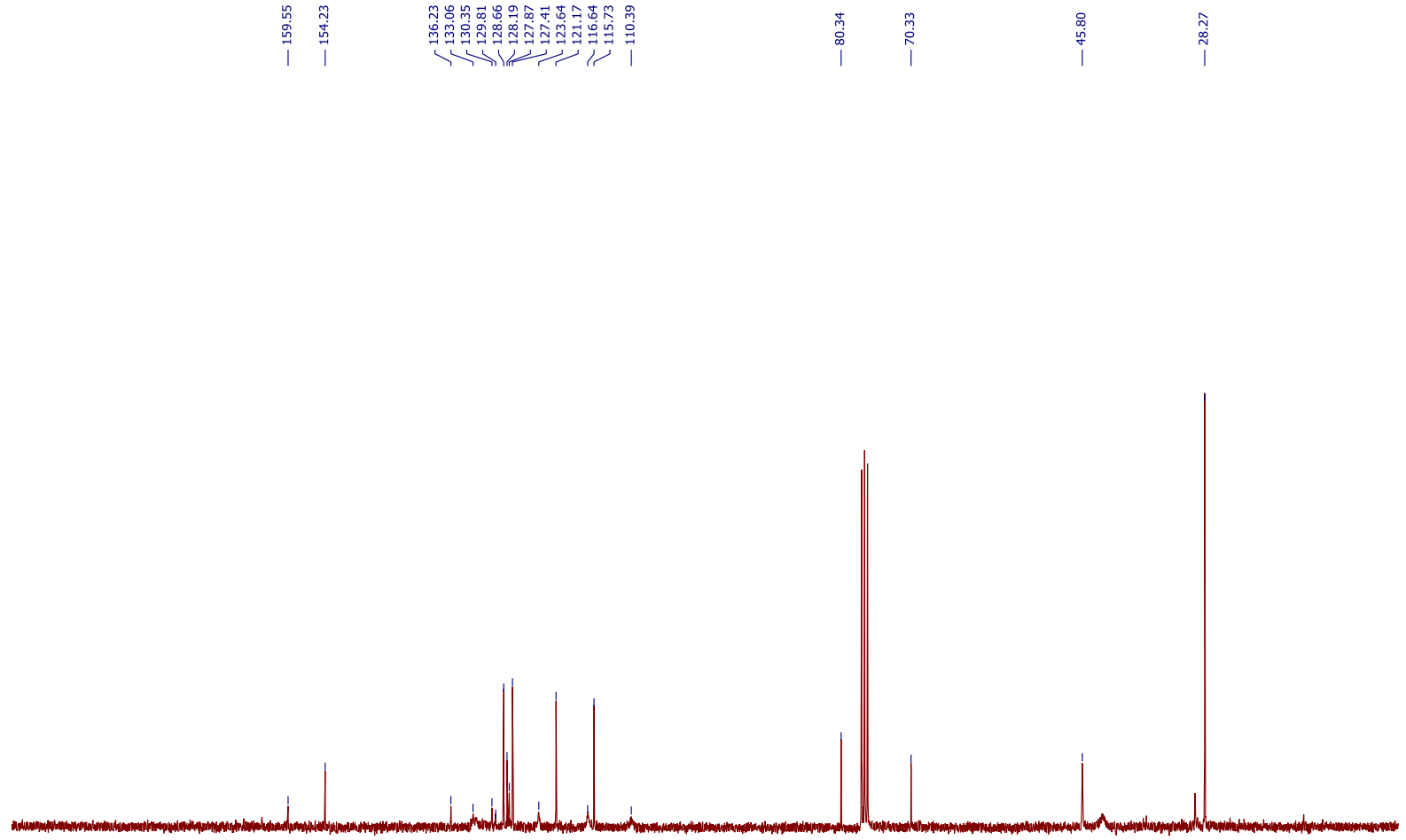

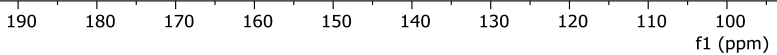



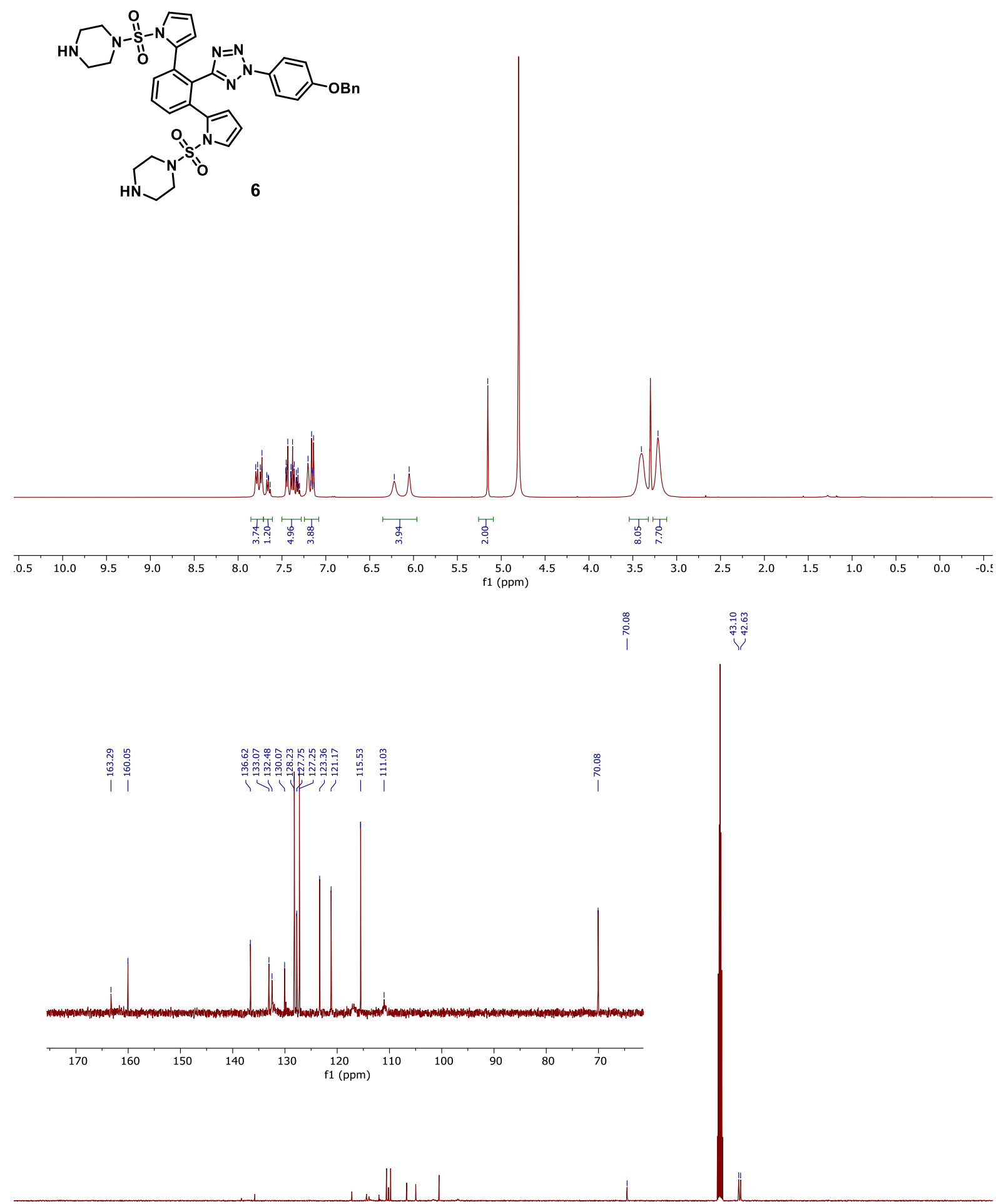

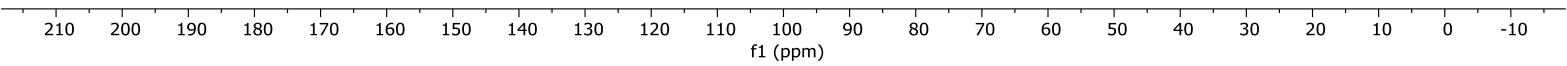




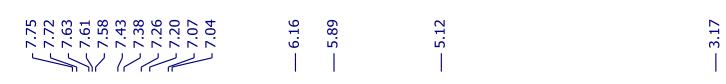
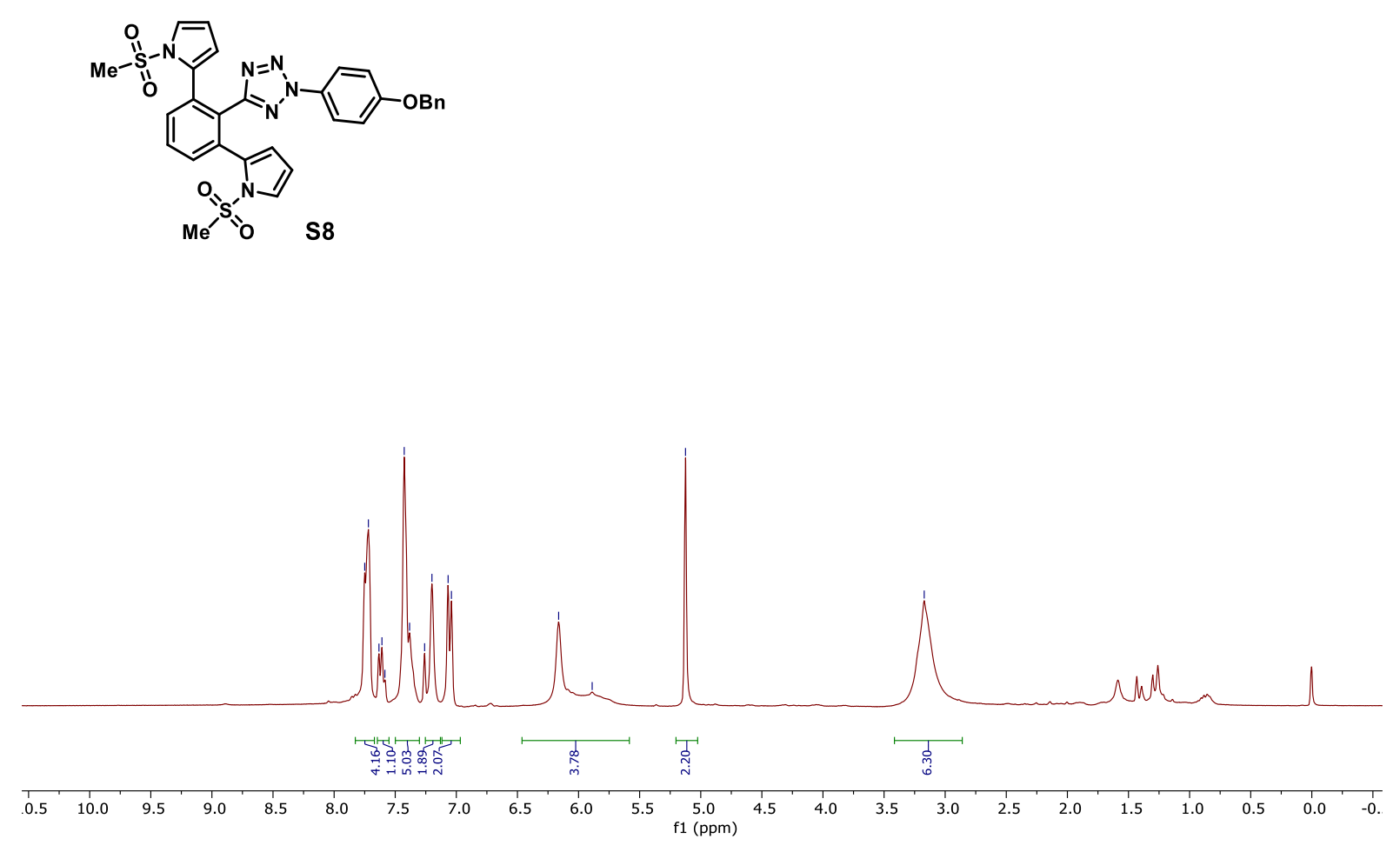

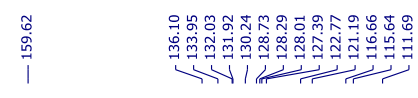

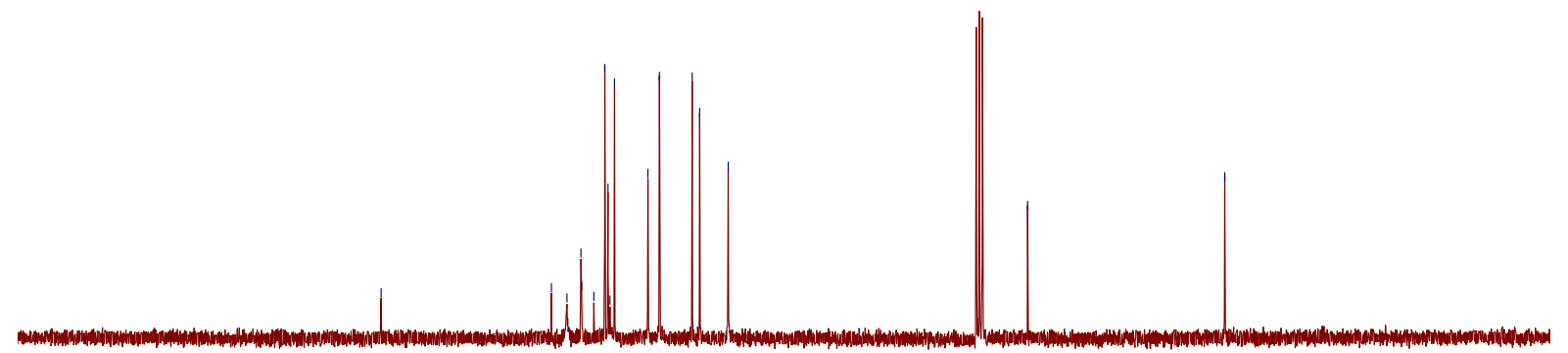

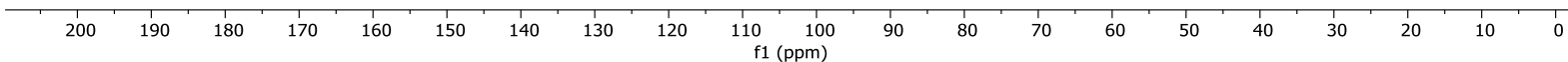



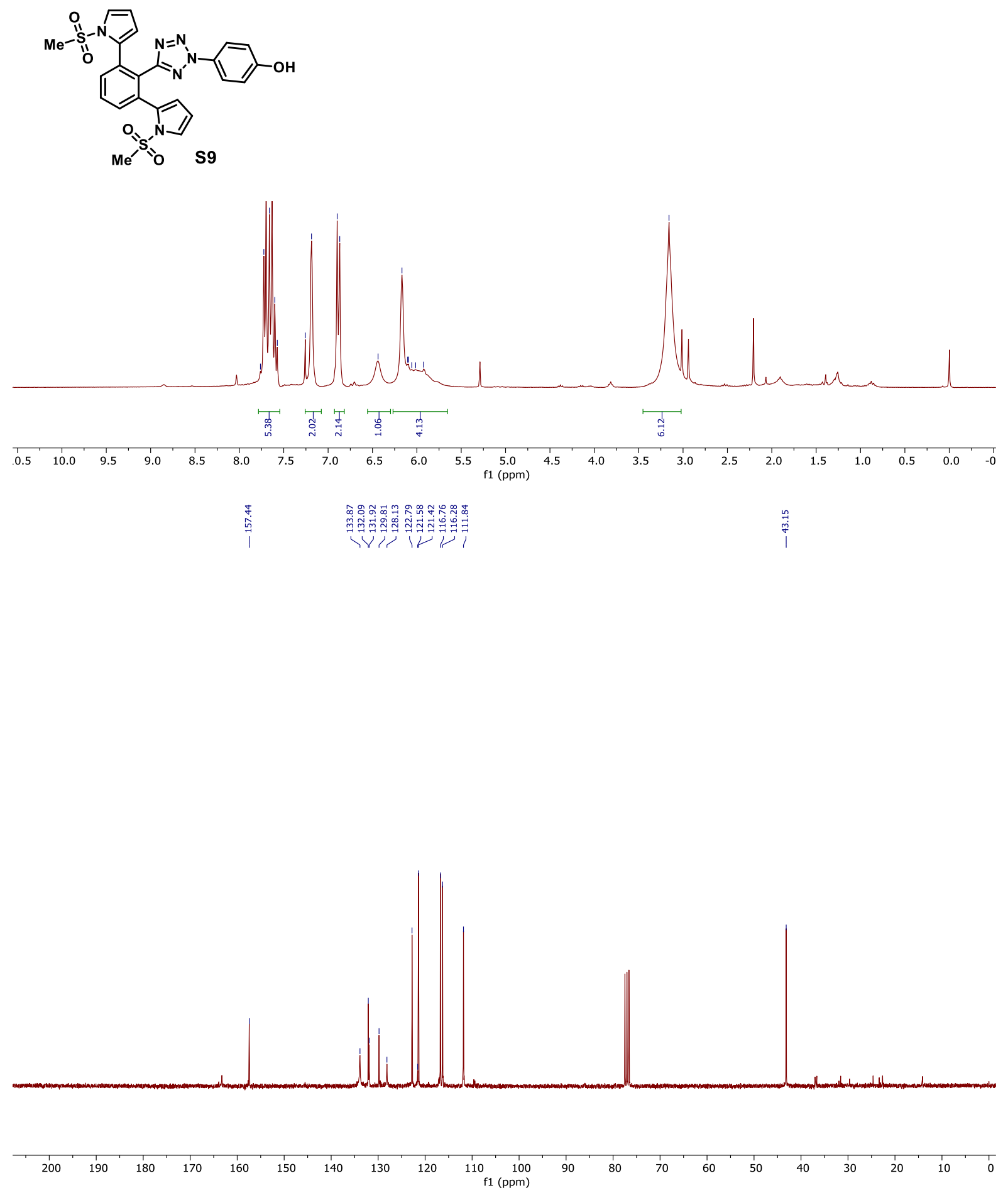


\section{$\underbrace{n=1}$}
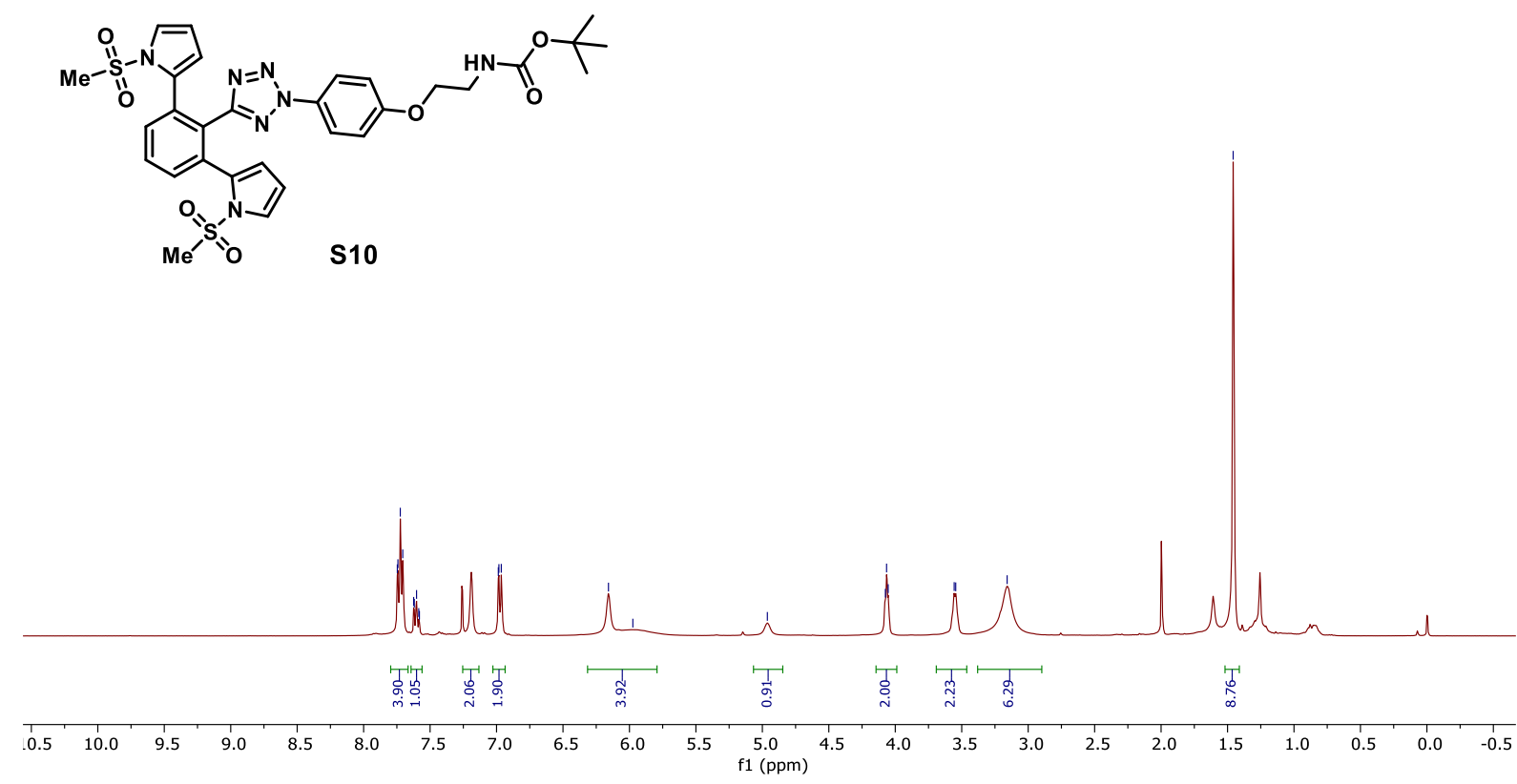

0
L

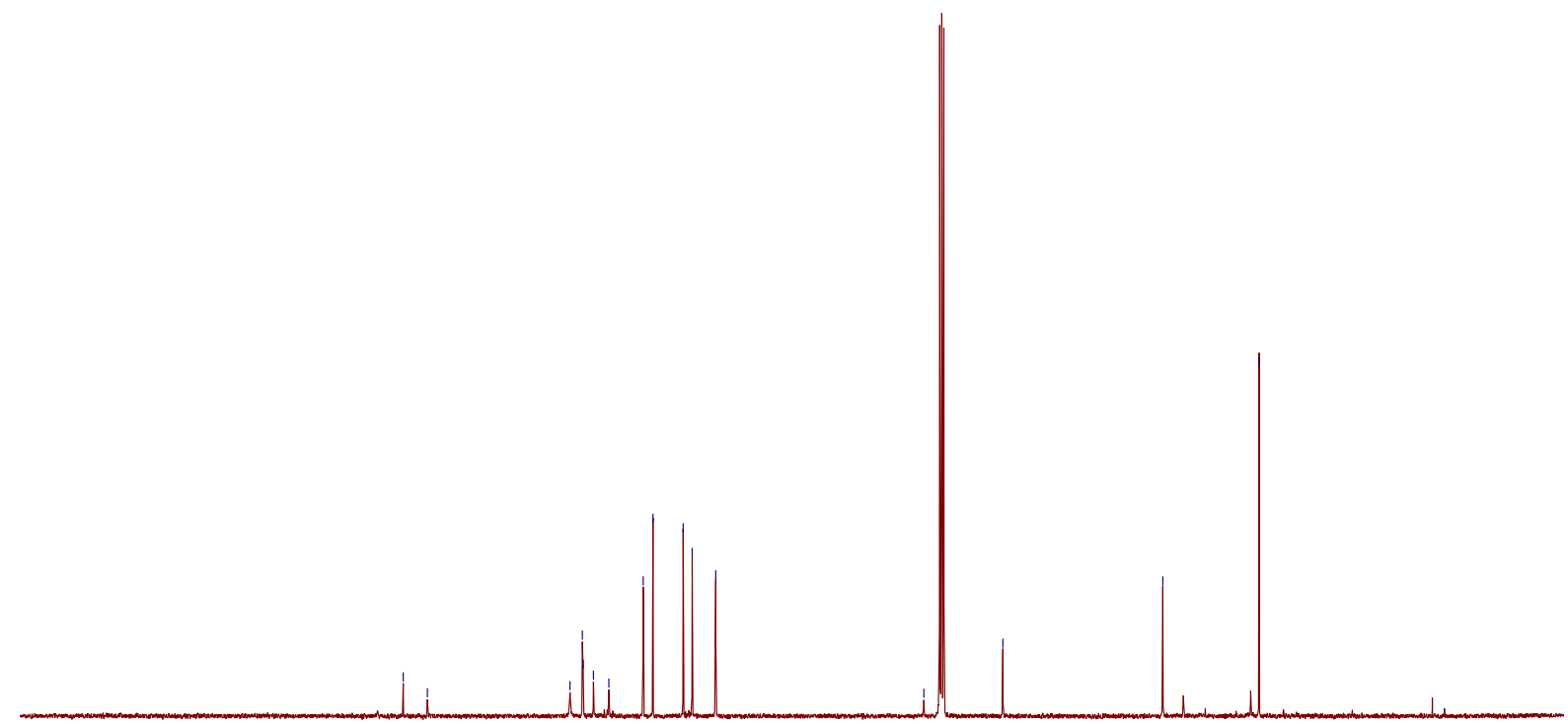

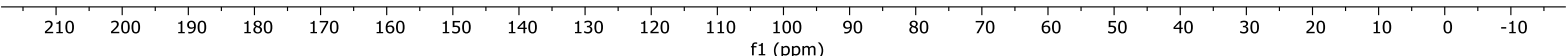




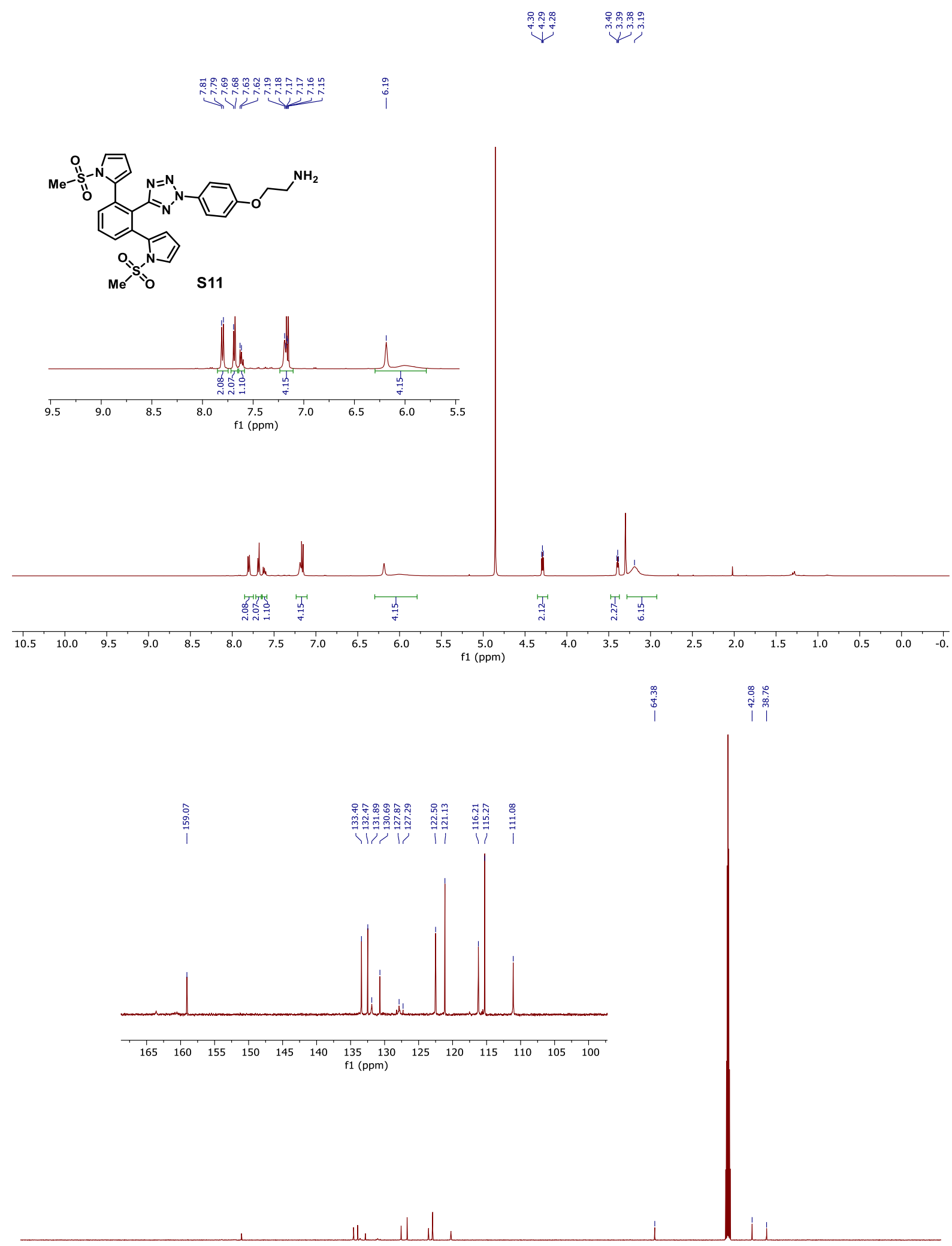

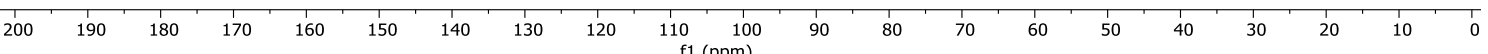




\section{Computed Structures and Cartesian Coordinates}

\section{R-BCN, end-on}

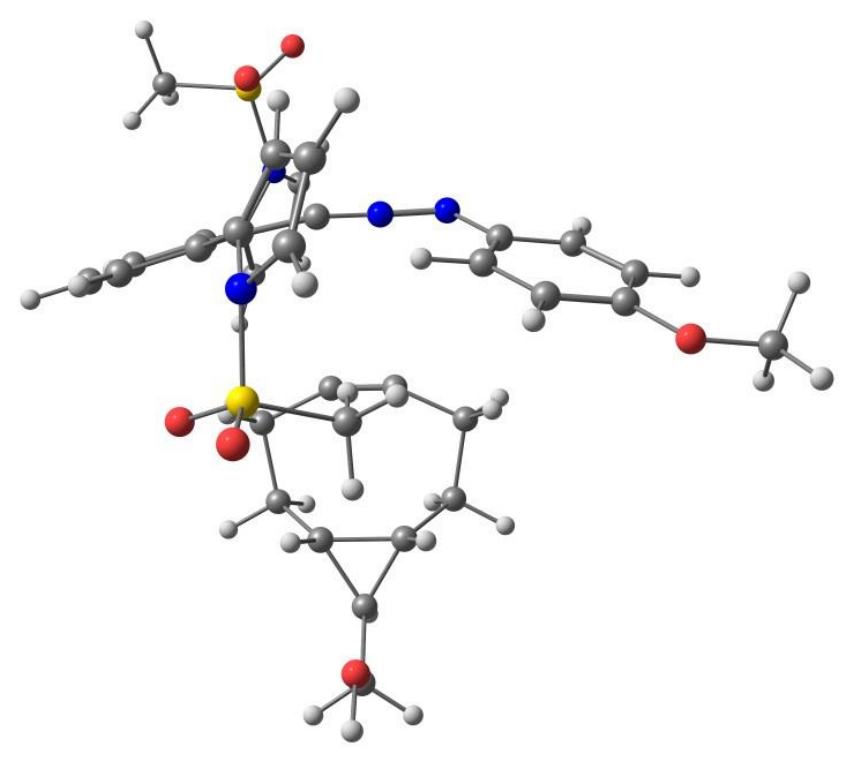

Figure S23. NI-BCN reactant complex with BCN in end-on configuration. The geometry was optimized at the B3LYP-D3/6-31+G(d)/SMD(water) level of theory.

$\begin{array}{llll}\text { C } & -5.097262000 & 5.424571000 & 0.425315000 \\ \text { O } & -4.477250000 & 4.391080000 & -0.349334000 \\ \text { C } & -3.186968000 & 4.021029000 & -0.019826000 \\ \text { C } & -2.618711000 & 3.010015000 & -0.807075000 \\ \text { C } & -1.327942000 & 2.556736000 & -0.554861000 \\ \text { C } & -0.571062000 & 3.105340000 & 0.500062000 \\ \text { N } & 0.732026000 & 2.685440000 & 0.851578000 \\ \text { N } & 1.140564000 & 1.654197000 & 0.227626000 \\ \text { C } & 1.573087000 & 0.711023000 & -0.309398000 \\ \text { C } & 1.977428000 & -0.578284000 & -0.732243000 \\ \text { C } & 2.898133000 & -1.315494000 & 0.057790000 \\ \text { C } & 3.201208000 & -2.627799000 & -0.315118000 \\ \text { C } & 2.622058000 & -3.200231000 & -1.451588000 \\ \text { C } & 1.750154000 & -2.456682000 & -2.245552000 \\ \text { C } & 1.417700000 & -1.138436000 & -1.907660000 \\ \text { C } & 0.571142000 & -0.302412000 & -2.772412000\end{array}$




\begin{tabular}{|c|c|c|c|}
\hline$C$ & 0.890009000 & 0.917437000 & 041000 \\
\hline$C$ & -0.182035000 & 1.334837000 & -4.173223000 \\
\hline$C$ & -1.147100000 & 0.366493000 & -4.130332000 \\
\hline $\mathrm{N}$ & -0.685909000 & -0.674043000 & -3.309146000 \\
\hline D & -1.851465000 & -1.708326000 & -2.569506000 \\
\hline 0 & -1.145437000 & -2.873014000 & -2.023851000 \\
\hline ) & -2.880896000 & -1.917232000 & -3.601061000 \\
\hline E & -2.529261000 & -0.719332000 & -1.243240000 \\
\hline $\mathrm{H}$ & -2.889850000 & 0.214386000 & -1.677448000 \\
\hline H & -1.747546000 & -0.550440000 & -0.500573000 \\
\hline $\mathrm{H}$ & -3.356082000 & -1.297173000 & -0.824598000 \\
\hline $\mathrm{H}$ & -2.113785000 & 0.299670000 & -4.606371000 \\
\hline $\mathrm{H}$ & -0.224753000 & 2.241238000 & -4.763108000 \\
\hline $\mathrm{H}$ & 1.826395000 & 1.434973000 & -3.160228000 \\
\hline H & 1.328688000 & -2.891922000 & -3.144847000 \\
\hline H & 2.870509000 & -4.220076000 & -1.729978000 \\
\hline H & 3.899857000 & -3.196 & 000 \\
\hline$C$ & 3.462073000 & -0.761181000 & 1.298247000 \\
\hline C & 3.329786000 & -1.230744000 & 2.582975000 \\
\hline C & 4.029066000 & -0.349390000 & 3.468805000 \\
\hline C & 4.591814000 & 0.642569000 & 2.714615000 \\
\hline $\mathrm{N}$ & 4.217537000 & 0.436707000 & 1.377901000 \\
\hline$S$ & 5.217214000 & 1.039931000 & 0.111977000 \\
\hline 0 & 5.864478000 & 2.242275000 & 0.659771000 \\
\hline 0 & 4.388416000 & 1.169004000 & -1.092991000 \\
\hline C & 6.422598000 & -0.263494000 & -0.122576000 \\
\hline$H$ & 6.939049000 & -0.418961000 & 0.827391000 \\
\hline $\mathrm{H}$ & 5.889326000 & -1.162177000 & -0.441354000 \\
\hline $\mathrm{H}$ & 7.113709000 & 0.079661000 & -0.898000000 \\
\hline $\mathrm{H}$ & 5.206632000 & 1.487600000 & 2.985159000 \\
\hline $\mathrm{H}$ & 4.087015000 & -0.430247000 & 4.546661000 \\
\hline $\mathrm{H}$ & 2.743671000 & -2.097192000 & 2.859835000 \\
\hline C & -1.143410000 & 4.126391000 & 1.273088000 \\
\hline C & -2.440357000 & 4.584456000 & 1.023421000 \\
\hline H & -2.850786000 & 5.368649000 & 1.649480000 \\
\hline $\mathrm{H}$ & -0.571349000 & 4.556513000 & 2.091086000 \\
\hline $\mathrm{H}$ & -0.914084000 & 1.770153000 & -1.177748000 \\
\hline $\mathrm{H}$ & -3.200632000 & 2.581180000 & -1.618719000 \\
\hline $\mathrm{H}$ & -6.093576000 & 5.555893000 & -0.000771000 \\
\hline $\mathrm{H}$ & -5.183677000 & 5.130055000 & 1.478282000 \\
\hline $\mathrm{H}$ & -4.537470000 & 6.364606000 & 0.347970000 \\
\hline C & -0.327870000 & -1.059408000 & 1.762610000 \\
\hline
\end{tabular}




$\begin{array}{lrrr}\text { C } & -0.954810000 & -0.068701000 & 2.081778000 \\ \text { C } & -0.148992000 & -2.500250000 & 1.554858000 \\ \text { C } & -2.133219000 & 0.650847000 & 2.576123000 \\ \text { C } & -3.074000000 & -0.439882000 & 3.169985000 \\ \text { H } & -2.631871000 & 1.184436000 & 1.755747000 \\ \text { H } & -1.885246000 & 1.398557000 & 3.338648000 \\ \text { C } & -3.495242000 & -1.493408000 & 2.154950000 \\ \text { H } & -2.567869000 & -0.912046000 & 4.020483000 \\ \text { H } & -3.975261000 & 0.051915000 & 3.563541000 \\ \text { C } & -2.708108000 & -2.744619000 & 1.746211000 \\ \text { C } & -3.961156000 & -2.865699000 & 2.580462000 \\ \text { H } & -4.052769000 & -1.062566000 & 1.323348000 \\ \text { C } & -1.349590000 & -3.182586000 & 2.275854000 \\ \text { H } & -2.839277000 & -2.991954000 & 0.693085000 \\ \text { H } & -1.275174000 & -2.973265000 & 3.349821000 \\ \text { H } & -1.257526000 & -4.271361000 & 2.152811000 \\ \text { H } & -0.155883000 & -2.740367000 & 0.484169000 \\ \text { H } & 0.798868000 & -2.872347000 & 1.958562000 \\ \text { H } & -3.790674000 & -3.101229000 & 3.632337000 \\ \text { C } & -5.232439000 & -3.497704000 & 2.060150000 \\ \text { H } & -6.092620000 & -3.145212000 & 2.648159000 \\ \text { H } & -5.174725000 & -4.591056000 & 2.164159000 \\ \text { O } & -5.425627000 & -3.156052000 & 0.672965000 \\ \text { H } & -6.232534000 & -3.600089000 & 0.365320000\end{array}$

\section{R-BCN, side-on}

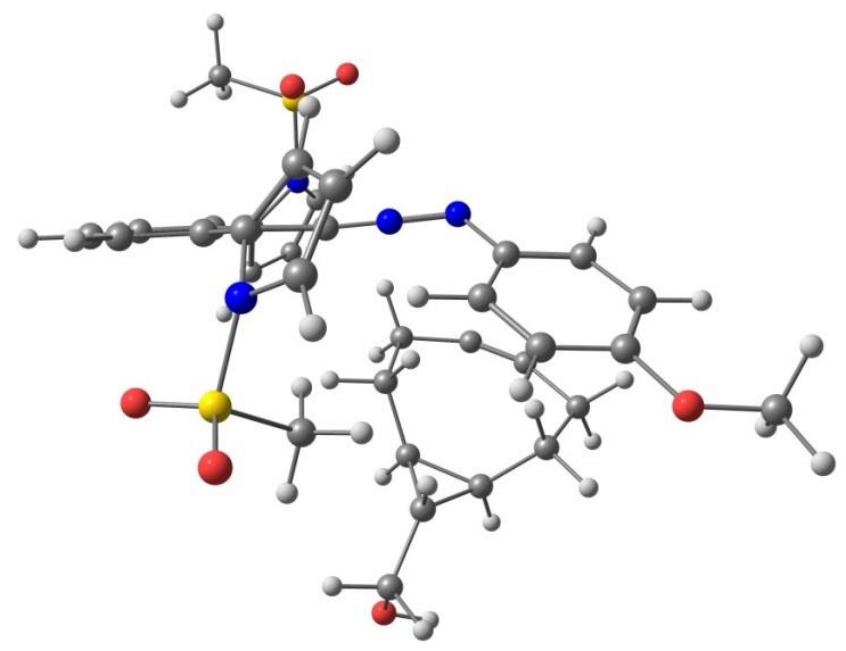


Figure S24. NI-BCN reactant complex with $B C N$ in side-on configuration. The geometry was optimized at the B3LYP-D3/6-31+G(d)/SMD(water) level of theory.

$\begin{array}{llll}\text { C } & 6.434631000 & -0.884915000 & -3.025772000 \\ \text { O } & 5.493638000 & 0.053757000 & -2.490148000 \\ \text { C } & 4.170042000 & -0.335231000 & -2.406192000 \\ \text { C } & 3.681762000 & -1.579249000 & -2.826417000 \\ \text { C } & 2.325927000 & -1.881121000 & -2.672369000 \\ \text { C } & 1.437645000 & -0.957147000 & -2.103262000 \\ \text { N } & 0.092988000 & -1.364149000 & -1.946865000 \\ \text { N } & -0.631460000 & -0.563591000 & -1.273244000 \\ \text { C } & -1.355566000 & 0.079735000 & -0.619235000 \\ \text { C } & -2.254534000 & 0.961444000 & 0.028049000 \\ \text { C } & -3.289595000 & 0.428508000 & 0.840420000 \\ \text { C } & -4.139113000 & 1.311220000 & 1.513844000 \\ \text { C } & -3.972006000 & 2.693889000 & 1.395798000 \\ \text { C } & -2.958408000 & 3.212557000 & 0.590978000 \\ \text { C } & -2.088787000 & 2.364094000 & -0.105042000 \\ \text { C } & -1.046787000 & 2.892214000 & -1.002702000 \\ \text { C } & -0.913224000 & 2.703793000 & -2.358633000 \\ \text { C } & 0.242265000 & 3.413864000 & -2.809798000 \\ \text { C } & 0.809915000 & 4.022810000 & -1.723722000 \\ \text { N } & 0.004750000 & 3.753540000 & -0.608657000 \\ \text { S } & 0.639687000 & 3.915873000 & 0.983086000 \\ \text { O } & -0.487421000 & 4.138322000 & 1.897410000 \\ \text { O } & 1.686270000 & 4.945201000 & 0.879827000 \\ \text { C } & 1.381172000 & 2.323124000 & 1.316098000 \\ \text { H } & 2.187125000 & 2.177574000 & 0.595070000 \\ \text { H } & 0.608566000 & 1.558182000 & 1.219352000 \\ \text { H } & 1.767870000 & 2.366780000 & 2.338188000 \\ \text { H } & 1.691741000 & 4.637498000 & -1.626795000 \\ \text { H } & 0.608216000 & 3.473823000 & -3.826540000 \\ \text { H } & -1.596723000 & 2.120409000 & -2.962468000 \\ \text { H } & -2.839371000 & 4.285494000 & 0.486363000 \\ \text { H } & -4.642898000 & 3.366593000 & 1.921810000 \\ \text { H } & -4.936617000 & 0.904770000 & 2.128468000 \\ \text { C } & -3.431095000 & -1.019577000 & 1.056071000 \\ \text { C } & -3.359049000 & -1.709926000 & 2.242083000 \\ & -3.524492000 & -3.105935000 & 1.971381000\end{array}$




\begin{tabular}{|c|c|c|c|}
\hline & 0 & 0 & \\
\hline & 3.607692000 & 00 & 00 \\
\hline & 200000 & $-1.67 \varepsilon$ & 00 \\
\hline & -3.832449000 & 230000 & 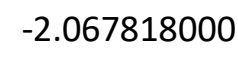 \\
\hline & -4.424941000 & -2.954707000 & \\
\hline & -6.102567000 & -1.290282000 & -0.90 \\
\hline & -6.0 & 00 & \\
\hline & -6 & -1 & \\
\hline & -6.4 & -2.1 & \\
\hline & -3.8 & -4.1 & \\
\hline & -3.4 & -3.9 & 2. \\
\hline & -3.1 & -1.2 & \\
\hline & 000 & 0.25 & -1.7 \\
\hline & 3.286930000 & 0.603155000 & -1.85 \\
\hline & 3.666599000 & 027000 & -1.5 \\
\hline & 1.27 & 1.0 & -1. \\
\hline & 1.9 & -2 & \\
\hline & & -2.3 & \\
\hline & 97000 & -1.7 & -2. \\
\hline & 00 & -1.1 & -4 \\
\hline & 7.403 & $-0.3 \varepsilon$ & -2.9 \\
\hline & 2.14 & -3.9 & 0.5 \\
\hline & 000 & -3.5 & 0.8 \\
\hline & 000 & -2.6 & 1.4 \\
\hline & 0.75 & -1.3 & 1.6 \\
\hline & 1.9 & -1.4 & \\
\hline & & $-1 . \varepsilon$ & \\
\hline & 7000 & -2.2 & \\
\hline & 44000 & -3.72 & 0.3 \\
\hline & 74000 & -4.4 & 1.0 \\
\hline & 3.943907000 & -3.89 & -0.6 \\
\hline & 3.3545 & -1.59 & 0.05 \\
\hline & 4.927705000 & -2.04686 & 0.707 \\
\hline & 3.878 & -2.47 & \\
\hline & 3.079888000 & -0.45 & כ. \\
\hline & 3.051536000 & 0.213863000 & 1.68821 \\
\hline & 3.617714000 & 0.243402000 & 3.78187600 \\
\hline & 2.966598000 & 1.084762000 & 100410600 \\
\hline & 0 & 0.6 & 3.57 \\
\hline & 3.659430000 & -0.581390000 & 4.9602250 \\
\hline & 4.317507000 & -1.282555000 & 4.8195 \\
\hline & 1.699100000 & -1.806291000 & 3.5961060 \\
\hline
\end{tabular}




$\begin{array}{lrrr}H & 1.073730000 & -0.935500000 & 0.709624000 \\ H & 0.040737000 & -0.634110000 & 2.102588000 \\ H & -0.394929000 & -3.088958000 & 2.350448000 \\ H & -0.836439000 & -2.527213000 & 0.744525000\end{array}$

\section{TS-BCN}

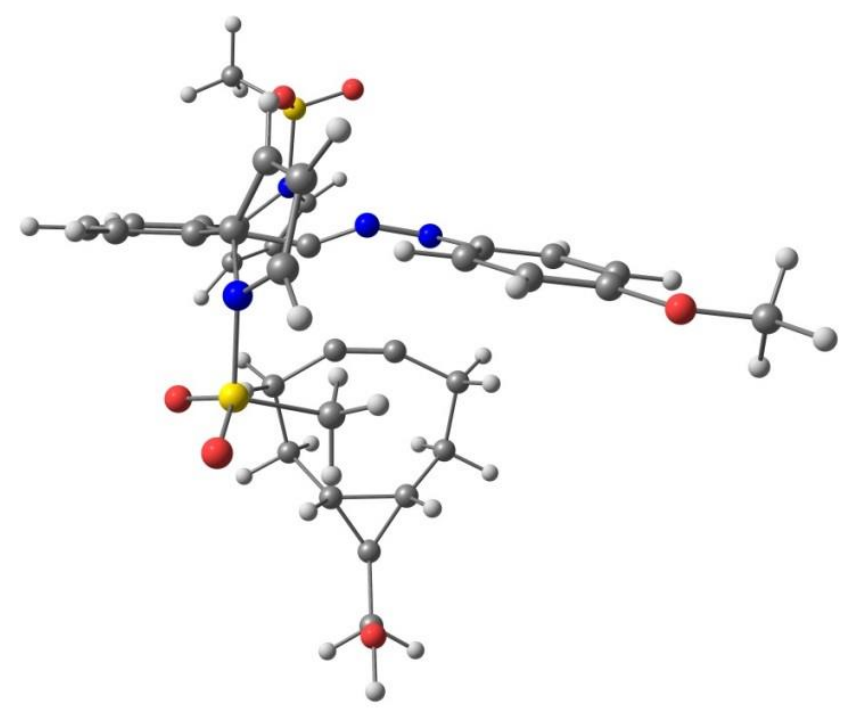

Figure S25. NI-BCN transition state (TS2) with BCN in end-on configuration. The geometry was optimized at the B3LYP-D3/6-31+G(d)/SMD(water) level of theory.

$\begin{array}{llll}\text { C } & 5.630698000 & 4.675023000 & -1.883537000 \\ \text { O } & 4.862871000 & 4.186751000 & -0.775284000 \\ \text { C } & 3.653433000 & 3.580142000 & -1.041612000 \\ \text { C } & 2.936293000 & 3.123194000 & 0.075414000 \\ \text { C } & 1.708283000 & 2.494886000 & -0.087535000 \\ \text { C } & 1.161963000 & 2.310101000 & -1.373466000 \\ \text { N } & -0.040607000 & 1.623938000 & -1.626503000 \\ \text { N } & -0.710737000 & 1.272610000 & -0.595383000 \\ \text { C } & -1.148362000 & 0.361350000 & 0.052092000 \\ \text { C } & -2.021114000 & -0.095607000 & 1.087640000 \\ \text { C } & -3.166190000 & -0.864778000 & 0.749742000 \\ \text { C } & -3.892074000 & -1.482298000 & 1.774374000 \\ \text { C } & -3.508652000 & -1.339702000 & 3.110104000 \\ \text { C } & -2.415016000 & -0.537698000 & 3.440401000\end{array}$




\begin{tabular}{|c|c|c|c|}
\hline C & -1.663282000 & 0.094221000 & 2.4435 \\
\hline C & -0.582565000 & 1.036506000 & 2.810908000 \\
\hline C & -0.652940000 & 2.408500000 & 2.849872000 \\
\hline$C$ & 0.577605000 & 2.920351000 & 3.373012000 \\
\hline 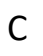 & 1.388553000 & 1.853678000 & 3.647699000 \\
\hline V & 0.676833000 & 0.683742000 & 3.347012000 \\
\hline & 1.520477000 & -0.791588000 & 3.103671000 \\
\hline 0 & 0.519553000 & -1.865547000 & 3.074472000 \\
\hline 0 & 2.567604000 & -0.814859000 & 377000 \\
\hline C & 2.288479000 & -0.602287000 & 250000 \\
\hline $\mathrm{H}$ & 2.905786000 & 0.297310000 & 1.531552000 \\
\hline $\mathrm{H}$ & 1.508511000 & -0.523049000 & 0.739921000 \\
\hline $\mathrm{H}$ & 2.903253000 & -1.492121000 & 1.342889000 \\
\hline $\mathrm{H}$ & 2.396635000 & 1.799237000 & 4.031323000 \\
\hline $\mathrm{H}$ & 0.829942000 & 3.960580000 & 3.532995000 \\
\hline H & -1.523096000 & 2.981233000 & 2.554718000 \\
\hline H & -2.139514000 & -0.387862000 & 4.480291000 \\
\hline $\mathrm{H}$ & -4.080292000 & -1.828295000 & 3.893648000 \\
\hline $\mathrm{H}$ & -4.770577000 & -2.066117000 & 1.515259000 \\
\hline C & -3.568929000 & -1.070730000 & -0.648193000 \\
\hline C & -3.765424000 & -2.255952000 & -1.315691000 \\
\hline C & -4.060661000 & -1.969714000 & -2.687453000 \\
\hline C & -4.056106000 & -0.611878000 & -2.840405000 \\
\hline $\mathrm{N}$ & -3.714619000 & -0.031107000 & -1.605824000 \\
\hline$S$ & -4.394203000 & 1.513399000 & -1.238362000 \\
\hline $\mathrm{O}$ & -4.327618000 & 2.277800000 & -2.494135000 \\
\hline $\mathrm{O}$ & -3.720063000 & 2.043757000 & -0.048573000 \\
\hline C & -6.097035000 & 1.125294000 & -0.839536000 \\
\hline $\mathrm{H}$ & -6.540634000 & 0.623666000 & -1.702338000 \\
\hline $\mathrm{H}$ & -6.095636000 & 0.480360000 & 0.042269000 \\
\hline $\mathrm{H}$ & -6.599326000 & 2.074427000 & -0.631908000 \\
\hline $\mathrm{H}$ & -4.252422000 & 0.011665000 & -3.699790000 \\
\hline $\mathrm{H}$ & -4.228483000 & -2.692627000 & -3.475414000 \\
\hline $\mathrm{H}$ & -3.640166000 & -3.235283000 & -0.872050000 \\
\hline C & 1.880901000 & 2.780001000 & -2.482905000 \\
\hline C & 3.120180000 & 3.406537000 & -2.326297000 \\
\hline $\mathrm{H}$ & 3.651750000 & 3.750185000 & -3.206098000 \\
\hline $\mathrm{H}$ & 1.471384000 & 2.639346000 & -3.479553000 \\
\hline $\mathrm{H}$ & 1.169198000 & 2.145257000 & 0.784541000 \\
\hline $\mathrm{H}$ & 3.351348000 & 3.264009000 & 1.070101000 \\
\hline$\pi$ & 6.530973000 & 5.112164000 & -1.448254000 \\
\hline H & 5.907859000 & 3.857530000 & -2.559900000 \\
\hline
\end{tabular}




$\begin{array}{lrrr}\text { H } & 5.077829000 & 5.443924000 & -2.436489000 \\ \text { C } & -0.026853000 & -1.430178000 & -1.124569000 \\ \text { C } & 0.644423000 & -0.857716000 & -1.982604000 \\ \text { C } & -0.281782000 & -2.661694000 & -0.346801000 \\ \text { C } & 1.734881000 & -0.737084000 & -2.954588000 \\ \text { C } & 2.393235000 & -2.135578000 & -3.107905000 \\ \text { H } & 2.476881000 & -0.005642000 & -2.606736000 \\ \text { H } & 1.378946000 & -0.380484000 & -3.929170000 \\ \text { C } & 2.924903000 & -2.706137000 & -1.802100000 \\ \text { H } & 1.661099000 & -2.822974000 & -3.548229000 \\ \text { H } & 3.222928000 & -2.051277000 & -3.824547000 \\ \text { C } & 2.099087000 & -3.497299000 & -0.786346000 \\ \text { C } & 3.129593000 & -4.194821000 & -1.639924000 \\ \text { H } & 3.685503000 & -2.076707000 & -1.338476000 \\ \text { C } & 0.614205000 & -3.798765000 & -0.900423000 \\ \text { H } & 2.410162000 & -3.322261000 & 0.242554000 \\ \text { H } & 0.342091000 & -3.990960000 & -1.945362000 \\ \text { H } & 0.394008000 & -4.718306000 & -0.338653000 \\ \text { H } & -0.058503000 & -2.486781000 & 0.712769000 \\ \text { H } & -1.334501000 & -2.956577000 & -0.394606000 \\ \text { H } & 2.723855000 & -4.802059000 & -2.450787000 \\ \text { C } & 4.394345000 & -4.794050000 & -1.068242000 \\ \text { H } & 5.153168000 & -4.886813000 & -1.859059000 \\ \text { H } & 4.186239000 & -5.801041000 & -0.677662000 \\ \text { O } & 4.905946000 & -3.963354000 & -0.007060000 \\ \text { H } & 5.716537000 & -4.378202000 & 0.330320000\end{array}$

\section{P-BCN}




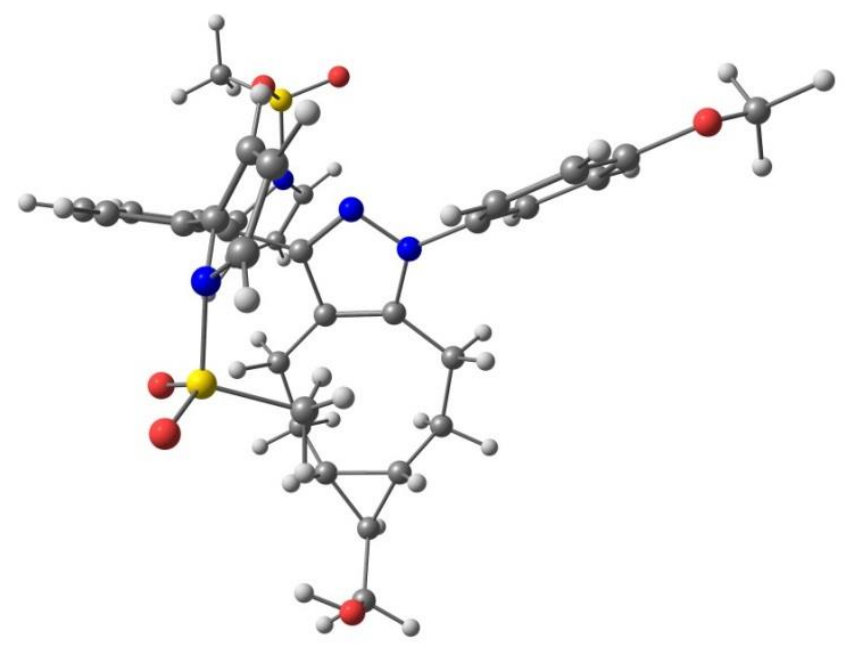

Figure S26. NI-BCN product. The geometry was optimized at the B3LYP-D3/6-31+G(d)/SMD(water) level of theory.

$\begin{array}{llll}\text { C } & 0.720886000 & 8.013227000 & 0.296070000 \\ \text { O } & 1.057145000 & 6.911360000 & 1.152504000 \\ \text { C } & 0.790309000 & 5.638942000 & 0.711117000 \\ \text { C } & 0.199686000 & 5.341304000 & -0.524685000 \\ \text { C } & -0.030849000 & 4.006162000 & -0.872330000 \\ \text { C } & 0.335353000 & 2.977861000 & -0.005864000 \\ \text { N } & 0.100730000 & 1.610345000 & -0.348046000 \\ \text { N } & -0.745408000 & 0.891620000 & 0.429431000 \\ \text { C } & -0.652812000 & -0.352920000 & -0.028410000 \\ \text { C } & -1.361707000 & -1.485508000 & 0.619938000 \\ \text { C } & -2.385389000 & -2.184910000 & -0.064001000 \\ \text { C } & -2.895272000 & -3.377988000 & 0.463960000 \\ \text { C } & -2.421030000 & -3.875273000 & 1.679513000 \\ \text { C } & -1.474551000 & -3.147970000 & 2.397648000 \\ \text { C } & -0.948844000 & -1.949365000 & 1.887233000 \\ \text { C } & -0.057975000 & -1.147481000 & 2.762149000 \\ \text { C } & -0.410389000 & -0.070928000 & 3.537734000 \\ \text { C } & 0.703000000 & 0.298220000 & 4.359854000 \\ \text { C } & 1.725544000 & -0.566495000 & 4.085897000 \\ \text { N } & 1.264109000 & -1.490869000 & 3.134389000 \\ \text { S } & 2.412503000 & -2.308735000 & 2.160529000 \\ \text { O } & 1.684393000 & -3.298539000 & 1.356122000\end{array}$




\begin{tabular}{|c|c|c|c|}
\hline 0 & 3.457911000 & -2.770828000 & 3.090077000 \\
\hline$C$ & 3.088441000 & -1.016060000 & 1.120492000 \\
\hline$H$ & 3.438247000 & -0.216003000 & 1.776484000 \\
\hline H & 2.302216000 & -0.667640000 & 0.449119000 \\
\hline$H$ & 3.921918000 & -1.456360000 & 0.568327000 \\
\hline$y$ & 2.734196000 & -0.629356000 & 4.467012000 \\
\hline & 0.733672000 & 1.101313000 & 5.085154000 \\
\hline - & -1.391169000 & 0.386018000 & 3.531834000 \\
\hline $\mathrm{H}$ & -1.139784000 & -3.498640000 & 3.370 \\
\hline $\mathrm{H}$ & -2.817636000 & -4.803151000 & 2.08 \\
\hline $\mathrm{H}$ & -3.680831000 & -3.900743000 & -0.074494000 \\
\hline C & -2.944344000 & -1.681394000 & -1.333782000 \\
\hline C & -2.928559000 & -2.250917000 & -2.582806000 \\
\hline C & -3.555365000 & -1.352528000 & -3.508705000 \\
\hline C & -3.963575000 & -0.252031000 & -2.810116000 \\
\hline$N$ & -3.563645000 & -0.410873000 & -1.469707000 \\
\hline$S$ & -4.575026000 & 0.278267000 & -0.255 \\
\hline $\mathrm{O}$ & -3.895755000 & 0.172988000 & 1.039581000 \\
\hline $\mathrm{O}$ & -4.940415000 & 1.611678000 & -0.763250000 \\
\hline C & -6.009596000 & -0.796769000 & -0.261 \\
\hline $\mathrm{H}$ & -5.676557000 & -1.798922000 & 0.019022000 \\
\hline $\mathrm{H}$ & -6.710819000 & -0.395571000 & 0.475891000 \\
\hline $\mathrm{H}$ & -6.441136000 & -0.783919000 & -1.264721000 \\
\hline $\mathrm{H}$ & -4.492058000 & 0.637528000 & -3.119190000 \\
\hline $\mathrm{H}$ & -3.665064000 & -1.499139000 & -4.575692000 \\
\hline $\mathrm{H}$ & -2.454941000 & -3.195115000 & -2.819743000 \\
\hline C & 0.923961000 & 3.278193000 & 1.229975000 \\
\hline C & 1.146746000 & 4.602579000 & 1.589655000 \\
\hline $\mathrm{H}$ & 1.600928000 & 4.850870000 & 2.544569000 \\
\hline $\mathrm{H}$ & 1.200981000 & 2.471897000 & 1.903189000 \\
\hline $\mathrm{H}$ & -0.499309000 & 3.769697000 & -1.823017000 \\
\hline $\mathrm{H}$ & -0.092013000 & 6.125977000 & -1.212591000 \\
\hline $\mathrm{H}$ & 1.271753000 & 7.955579000 & -0.649910000 \\
\hline $\mathrm{H}$ & -0.357200000 & 8.042534000 & 0.100243000 \\
\hline $\mathrm{H}$ & 1.019840000 & 8.909557000 & 0.841831000 \\
\hline C & 0.272964000 & -0.461517000 & -1.119544000 \\
\hline C & 0.759593000 & 0.839975000 & -1.289791000 \\
\hline C & 1.783865000 & 1.570684000 & -2.129750000 \\
\hline C & 2.695988000 & 0.801177000 & -3.088780000 \\
\hline C & 3.532351000 & -0.275343000 & -2.430745000 \\
\hline C & 3.000364000 & -1.690280000 & -2.323190000 \\
\hline C & 1.609460000 & -2.023040000 & -2.812608000 \\
\hline
\end{tabular}




$\begin{array}{llll}\mathrm{C} & 0.535963000 & -1.821821000 & -1.738475000 \\ \mathrm{H} & 0.766919000 & -2.502599000 & -0.908264000 \\ \mathrm{H} & -0.409675000 & -2.183853000 & -2.152855000 \\ \mathrm{H} & 1.362734000 & -1.454637000 & -3.715218000 \\ \mathrm{H} & 1.573005000 & -3.082069000 & -3.104802000 \\ \mathrm{H} & 3.269449000 & -2.228072000 & -1.415306000 \\ \mathrm{C} & 4.130824000 & -1.377534000 & -3.272187000 \\ \mathrm{H} & 3.867784000 & -1.358235000 & -4.331505000 \\ \mathrm{C} & 5.541268000 & -1.889717000 & -3.045659000 \\ \mathrm{H} & 6.259123000 & -1.248149000 & -3.568341000 \\ \mathrm{H} & 5.640140000 & -2.907062000 & -3.451249000 \\ \mathrm{O} & 5.963965000 & -1.878540000 & -1.668990000 \\ \mathrm{H} & 5.429877000 & -2.523759000 & -1.175879000 \\ \mathrm{H} & 4.132428000 & 0.068317000 & -1.587647000 \\ \mathrm{H} & 2.109873000 & 0.382817000 & -3.912769000 \\ \mathrm{H} & 3.363980000 & 1.544347000 & -3.545697000 \\ \mathrm{H} & 2.423660000 & 2.126627000 & -1.429732000 \\ \mathrm{H} & 1.259549000 & 2.337694000 & -2.713160000\end{array}$

R-Sph, side-on

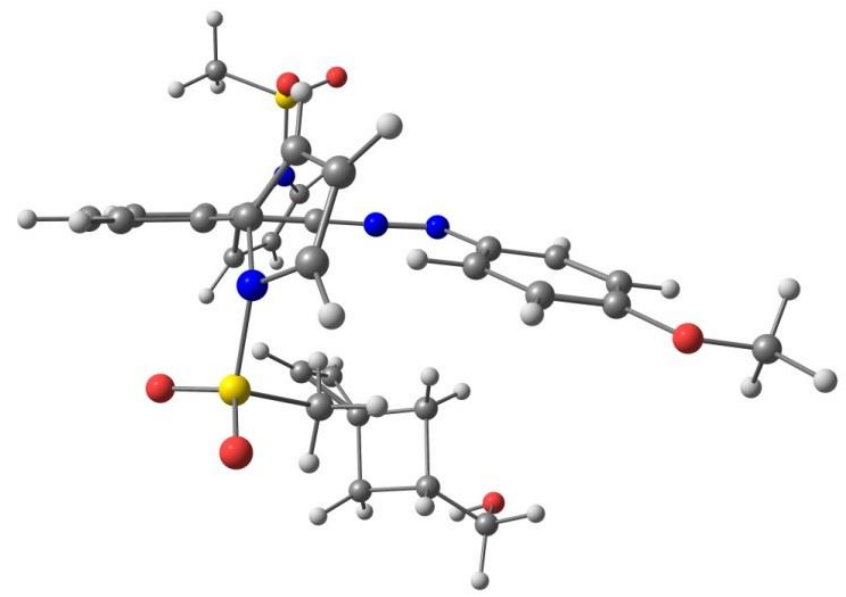

Figure S27. NI-Sph reactant complex with Sph in side-on configuration. The geometry was optimized at the B3LYP-D3/6-31+G(d)/SMD(water) level of theory. 


\begin{tabular}{|c|c|c|c|}
\hline 0 & 5.646561000 & -0.104413000 & 2000 \\
\hline C & 4.353590000 & -0.515391000 & -2.531020000 \\
\hline & 3.481988000 & 0.468523000 & -2.043132000 \\
\hline 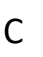 & 2.161059000 & 0.153962000 & -1.743394000 \\
\hline C & 1.676926000 & -1.157333000 & -1.920229000 \\
\hline N & 0.364135000 & -1.570438000 & -1.602389000 \\
\hline $\mathrm{N}$ & -0.361722000 & -0.673905000 & -1.063980000 \\
\hline C & -1.098381000 & 0.083158000 & -0.5643 \\
\hline C & -1.996813000 & 0.9731 & 3000 \\
\hline C & -3.167291000 & 0.463181000 & 0.693411000 \\
\hline C & -3.999232000 & 1.351559000 & 1.381638000 \\
\hline C & -3.695079000 & 2.713980000 & 1.452582000 \\
\hline C & -2.557431000 & 3.210212000 & 0.816394000 \\
\hline C & -1.698580000 & 2.357340000 & 0.114606000 \\
\hline C & -0.527880000 & 2.881834000 & -0.615184000 \\
\hline C & -0.335331000 & 2.958804000 & -1.974122000 \\
\hline C & 0.929103000 & 3.580021000 & -2.224841000 \\
\hline C & 1.499874000 & 3.869655000 & -1.0156 \\
\hline$N$ & 0.598062000 & 3.489507000 & -0.011903000 \\
\hline S & 1.147104000 & 3.221943000 & 1.595507000 \\
\hline $\mathrm{O}$ & -0.021728000 & 3.296870000 & 2.481743000 \\
\hline O & 2.255880000 & 4.169651000 & 1.790725000 \\
\hline C & 1.769939000 & 1.546212000 & 1.566031000 \\
\hline $\mathrm{H}$ & 2.614472000 & 1.509781000 & 0.876213000 \\
\hline $\mathrm{H}$ & 0.958906000 & 0.897551000 & 1.238036000 \\
\hline $\mathrm{H}$ & 2.075649000 & 1.304052000 & 2.587296000 \\
\hline $\mathrm{H}$ & 2.446067000 & 4.321649000 & -0.758888000 \\
\hline $\mathrm{H}$ & 1.363709000 & 3.794562000 & -3.192513000 \\
\hline $\mathrm{H}$ & -1.051155000 & 2.616994000 & -2.710979000 \\
\hline $\mathrm{H}$ & -2.327619000 & 4.270328000 & 0.853669000 \\
\hline $\mathrm{H}$ & -4.354645000 & 3.388876000 & 1.989862000 \\
\hline $\mathrm{H}$ & -4.894120000 & 0.963680000 & 1.859042000 \\
\hline C & -3.466116000 & -0.975862000 & 0.717500000 \\
\hline C & -3.606065000 & -1.791576000 & 1.813919000 \\
\hline C & -3.829320000 & -3.132446000 & 1.364175000 \\
\hline C & -3.835902000 & -3.119275000 & -0.002762000 \\
\hline$N$ & -3.566378000 & -1.807839000 & -0.427872000 \\
\hline$S$ & -4.183136000 & -1.278511000 & -1.947372000 \\
\hline O & -4.161391000 & -2.464825000 & -2.817402000 \\
\hline O & -3.422975000 & -0.089480000 & -2.351063000 \\
\hline C & -5.871105000 & -0.816040000 & -1.569162000 \\
\hline $\mathrm{H}$ & -6.371669000 & -1.688721000 & -1.143797000 \\
\hline
\end{tabular}




$\begin{array}{lrrr}\text { H } & -5.841589000 & 0.015089000 & -0.860505000 \\ \text { H } & -6.336350000 & -0.512770000 & -2.511373000 \\ \text { H } & -3.987588000 & -3.906292000 & -0.726020000 \\ \text { H } & -3.944083000 & -4.010790000 & 1.986152000 \\ \text { H } & -3.489764000 & -1.461576000 & 2.838069000 \\ \text { C } & 2.553488000 & -2.131992000 & -2.418796000 \\ \text { C } & 3.882042000 & -1.821107000 & -2.723428000 \\ \text { H } & 4.531812000 & -2.602448000 & -3.100944000 \\ \text { H } & 2.195223000 & -3.148827000 & -2.556757000 \\ \text { H } & 1.509646000 & 0.931337000 & -1.362231000 \\ \text { H } & 3.847231000 & 1.482169000 & -1.899170000 \\ \text { H } & 7.520684000 & -0.550319000 & -3.408437000 \\ \text { H } & 6.706136000 & -1.894989000 & -2.556245000 \\ \text { H } & 6.248588000 & -1.489176000 & -4.243132000 \\ \text { C } & -0.268313000 & -1.200506000 & 2.508710000 \\ \text { C } & 1.101950000 & -1.795231000 & 2.611301000 \\ \text { C } & -0.222517000 & -2.494864000 & 2.654068000 \\ \text { H } & -0.744728000 & -3.439428000 & 2.741759000 \\ \text { C } & 2.209404000 & -1.872208000 & 1.537402000 \\ \text { H } & 2.152711000 & -1.129066000 & 0.737859000 \\ \text { H } & 2.314986000 & -2.864078000 & 1.080847000 \\ \text { C } & 3.263149000 & -1.572324000 & 2.645608000 \\ \text { H } & 3.696693000 & -0.571089000 & 2.537568000 \\ \mathrm{C} & 2.144120000 & -1.601558000 & 3.734862000 \\ \text { H } & 2.207883000 & -2.445084000 & 4.436556000 \\ \text { H } & 2.039171000 & -0.678045000 & 4.317473000 \\ \text { C } & 4.418745000 & -2.551992000 & 2.793561000 \\ \text { H } & 5.023090000 & -2.292366000 & 3.674950000 \\ \text { O } & 4.010622000 & -3.933512000 & 2.882801000 \\ \text { H } & 3.487671000 & -4.047030000 & 3.694142000 \\ \text { H } & 5.065198000 & -2.504637000 & 1.910624000 \\ \text { H } & -0.853026000 & -0.297423000 & 2.394843000\end{array}$

\section{R-Sph, end-on}




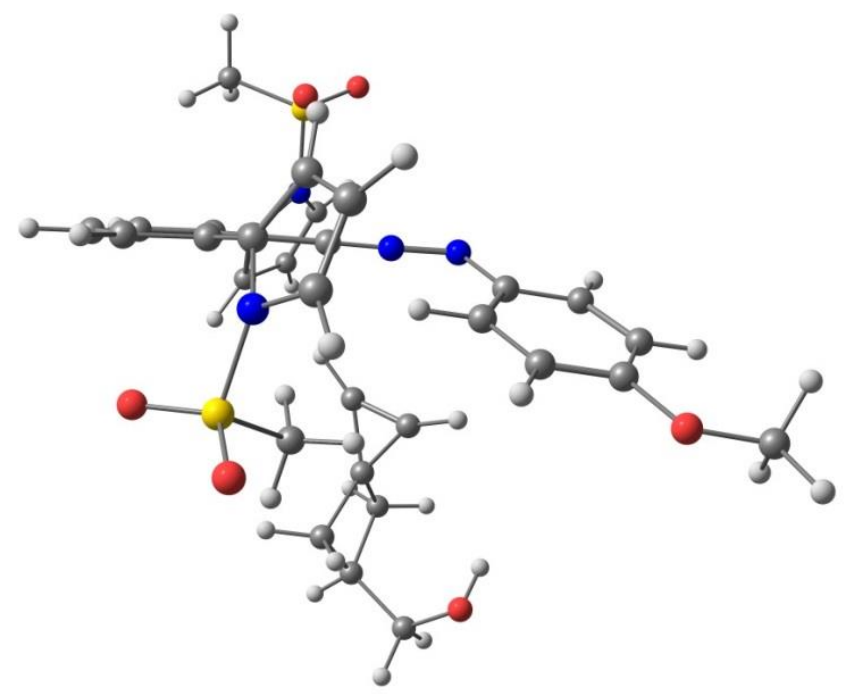

Figure S28. NI-Sph reactant complex with Sph in end-on configuration. The geometry was optimized at the B3LYP-D3/6-31+G(d)/SMD(water) level of theory.

$\begin{array}{llll}\text { C } & -6.278948000 & -1.256246000 & -3.783297000 \\ \text { O } & -5.410532000 & -1.689369000 & -2.728847000 \\ \text { C } & -4.113210000 & -1.213825000 & -2.721792000 \\ \text { C } & -3.305005000 & -1.648289000 & -1.661517000 \\ \text { C } & -1.984588000 & -1.223726000 & -1.561883000 \\ \text { C } & -1.436338000 & -0.348728000 & -2.520604000 \\ \text { N } & -0.116858000 & 0.154323000 & -2.475050000 \\ \text { N } & 0.541355000 & -0.180925000 & -1.438214000 \\ \text { C } & 1.208734000 & -0.433330000 & -0.513417000 \\ \text { C } & 2.006832000 & -0.731533000 & 0.615127000 \\ \text { C } & 3.062781000 & 0.144449000 & 0.982476000 \\ \text { C } & 3.799507000 & -0.140951000 & 2.135966000 \\ \text { C } & 3.505163000 & -1.262694000 & 2.916255000 \\ \text { C } & 2.475162000 & -2.126101000 & 2.542315000 \\ \text { C } & 1.716824000 & -1.881677000 & 1.392118000 \\ \text { C } & 0.665750000 & -2.814514000 & 0.941678000 \\ \text { C } & 0.649857000 & -3.600233000 & -0.187793000 \\ \text { C } & -0.575437000 & -4.335442000 & -0.218477000 \\ \text { C } & -1.303312000 & -3.983730000 & 0.886743000 \\ \text { N } & -0.538435000 & -3.079459000 & 1.631820000 \\ \text { S } & -1.231844000 & -2.133881000 & 2.890154000\end{array}$




\begin{tabular}{|c|c|c|c|}
\hline 0 & -0.192641000 & -1.911743000 & 3.904 \\
\hline 0 & -2.462214000 & -2.843714000 & 3.274702000 \\
\hline$C$ & -1.641057000 & -0.580576000 & 2.104088000 \\
\hline H & -2.367077000 & -0.777435000 & 1.313686000 \\
\hline$H$ & -0.725046000 & -0.141557000 & 1.708432000 \\
\hline$y$ & -2.069207000 & 0.052369000 & 2.885910000 \\
\hline & -2.278219000 & -4.291983000 & 1.232028000 \\
\hline & -0.885182000 & -5.046382000 & 2000 \\
\hline & 1.453731000 & -3.640665000 & 30000 \\
\hline H & 2.256390000 & -3.006687000 & 32000 \\
\hline H & 4.089642000 & -1.470696000 & 3.807480000 \\
\hline$H$ & 4.610957000 & 0.524263000 & 2.415441000 \\
\hline C & 3.332927000 & 1.381119000 & 0.232906000 \\
\hline$C$ & 3.272987000 & 2.677261000 & 0.686036000 \\
\hline$C$ & 3.563246000 & 3.558706000 & -0.404489000 \\
\hline$C$ & 3.809923000 & 2.790693000 & -1.508580000 \\
\hline$N$ & 3.628267000 & 1.445 & -1.152 \\
\hline$S$ & 4.476034000 & 0.218199000 & -2.015393000 \\
\hline $\mathrm{O}$ & 4.612254000 & 0.724737000 & -3.389843000 \\
\hline $\mathrm{O}$ & 3.773066000 & -1.051068000 & -1.793310000 \\
\hline C & 6.073388000 & 0.174072000 & -1.207032000 \\
\hline $\mathrm{H}$ & 6.513544000 & 1.171364000 & -1.277419000 \\
\hline $\mathrm{H}$ & 5.916710000 & -0.123132000 & -0.167360000 \\
\hline $\mathrm{H}$ & 6.678862000 & -0.564504000 & -1.740408000 \\
\hline $\mathrm{H}$ & 4.081960000 & 3.054957000 & -2.519376000 \\
\hline $\mathrm{H}$ & 3.564129000 & 4.640767000 & -0.377015000 \\
\hline$H$ & 2.989716000 & 2.959217000 & 1.692111000 \\
\hline C & -2.250164000 & 0.073375000 & -3.582112000 \\
\hline C & -3.578228000 & -0.351374000 & -3.688270000 \\
\hline $\mathrm{H}$ & -4.176990000 & 0.000702000 & -4.520543000 \\
\hline $\mathrm{H}$ & -1.842334000 & 0.750209000 & -4.328448000 \\
\hline $\mathrm{H}$ & -1.379116000 & -1.575710000 & -0.735286000 \\
\hline $\mathrm{H}$ & -3.718535000 & -2.323473000 & -0.916757000 \\
\hline $\mathrm{H}$ & -7.239308000 & -1.738229000 & -3.591516000 \\
\hline $\mathrm{H}$ & -6.403959000 & -0.166670000 & -3.767476000 \\
\hline $\mathrm{H}$ & -5.898256000 & -1.571860000 & -4.762279000 \\
\hline C & -0.514268000 & 2.402951000 & 0.405588000 \\
\hline C & -1.652409000 & 3.143664000 & 1.034309000 \\
\hline C & -1.690831000 & 2.187739000 & -0.113986000 \\
\hline $\mathrm{H}$ & -2.310675000 & 1.675492000 & -0.838445000 \\
\hline C & -2.316921000 & 2.976323000 & 2.419911000 \\
\hline H & -1.597290000 & 2.873616000 & 3.241647000 \\
\hline
\end{tabular}




$\begin{array}{llll}\text { H } & -3.061894000 & 2.175762000 & 2.500372000 \\ \text { C } & -2.887507000 & 4.421500000 & 2.277277000 \\ \text { H } & -2.656759000 & 5.087268000 & 3.116720000 \\ \text { C } & -1.992758000 & 4.649680000 & 1.017695000 \\ \text { H } & -2.499801000 & 5.023965000 & 0.116974000 \\ \text { H } & -1.128227000 & 5.294415000 & 1.218821000 \\ \text { C } & -4.389030000 & 4.504212000 & 2.028929000 \\ \text { H } & -4.669407000 & 5.537639000 & 1.777321000 \\ \text { O } & -4.864526000 & 3.613463000 & 0.997118000 \\ \text { H } & -4.408954000 & 3.830165000 & 0.165920000 \\ \text { H } & -4.937344000 & 4.209430000 & 2.929987000 \\ \text { H } & 0.548918000 & 2.198605000 & 0.418193000\end{array}$

TS-Sph

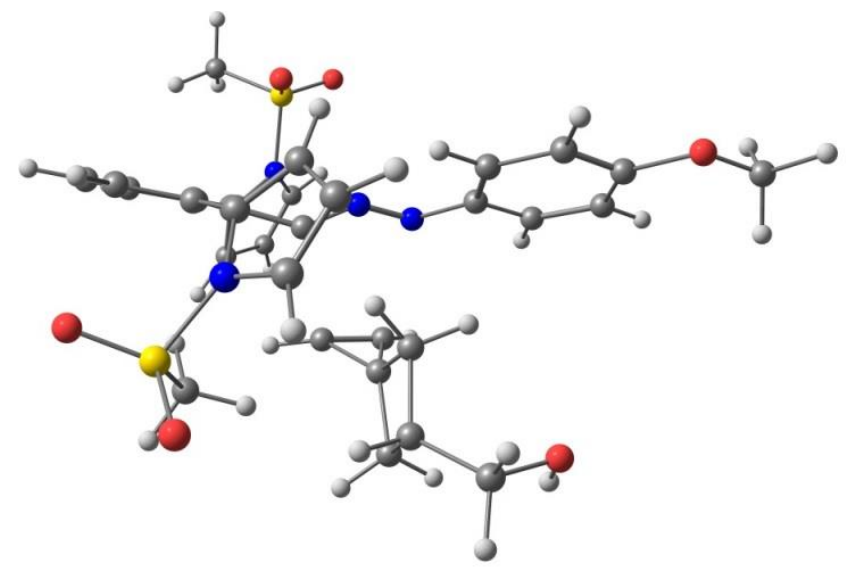

Figure S29. NI-Sph transition state (TS1) with Sph in side-on configuration. The geometry was optimized at the B3LYP-D3/6-31+G(d)/SMD(water) level of theory.

$\begin{array}{llll}\text { C } & 6.883833000 & -3.430678000 & -1.140917000 \\ \text { O } & 5.878306000 & -2.642556000 & -1.792569000 \\ \text { C } & 4.654873000 & -2.510777000 & -1.173074000 \\ \text { C } & 3.708451000 & -1.722235000 & -1.847254000 \\ \text { C } & 2.446444000 & -1.518426000 & -1.303410000 \\ \text { C } & 2.098456000 & -2.106077000 & -0.070411000 \\ \text { N } & 0.862215000 & -1.918059000 & 0.579351000 \\ \text { N } & 0.009579000 & -1.179969000 & -0.014564000\end{array}$




\begin{tabular}{|c|c|c|c|}
\hline C & -0.734287000 & -0.234647000 & 0.11 \\
\hline$C$ & -1.992618000 & 0.288719000 & -0.345913000 \\
\hline$C$ & -3.193139000 & -0.252137000 & 0.177187000 \\
\hline$C$ & -4.413143000 & 0.336051000 & -0.168500000 \\
\hline $\mathcal{L}$ & -4.454685000 & 1.433496000 & -1.033531000 \\
\hline & -3.272208000 & 1.958626000 & -1.554564000 \\
\hline & -2.030347000 & 1.411305000 & 67000 \\
\hline & -0.764479000 & 1.965778000 & -1.721452000 \\
\hline$C$ & 0.164550000 & 1.382165000 & 4000 \\
\hline$C$ & 1.255444000 & 2.287710000 & 58000 \\
\hline C & 0.990349000 & 3.413688000 & -1.994909000 \\
\hline $\mathrm{N}$ & -0.252145000 & 3.236042000 & -1.382252000 \\
\hline$S$ & -0.941478000 & 4.410097000 & -0.330279000 \\
\hline 0 & -2.257919000 & 4.793380000 & -0.862559000 \\
\hline $\mathrm{O}$ & 0.090078000 & 5.450078000 & -0.188199000 \\
\hline$c$ & -1.152921000 & 3.551051000 & 1.222391000 \\
\hline H & -0.181855000 & 3.174675000 & 1.538325000 \\
\hline $\mathrm{H}$ & -1.876403000 & 2.747344000 & 039000 \\
\hline $\mathrm{H}$ & -1.533043000 & 4.298845000 & 1.925025000 \\
\hline $\mathrm{H}$ & 90000 & 4.320934000 & -1.843376000 \\
\hline $\mathrm{H}$ & 2.145412000 & 2.121605000 & -3.322758000 \\
\hline $\mathrm{H}$ & 0.059582000 & 0.393606000 & -2.980130000 \\
\hline $\mathrm{H}$ & -3.302841000 & 2.802729000 & -2.234607000 \\
\hline $\mathrm{H}$ & -5.409450000 & 1.873235000 & -1.306390000 \\
\hline $\mathrm{H}$ & -5.331068000 & -0.082150000 & 0.234046000 \\
\hline C & -3.156004000 & -1.374374000 & 1.134356000 \\
\hline C & -3.416161000 & -1.365439000 & 2.482923000 \\
\hline C & -3.189395000 & -2.681888000 & 3.001995000 \\
\hline C & -2.800174000 & -3.480475000 & 1.961673000 \\
\hline $\mathrm{N}$ & -2.731085000 & -2.682996000 & 0.811138000 \\
\hline$S$ & -2.839499000 & -3.390886000 & -0.750065000 \\
\hline $\mathrm{O}$ & -2.231579000 & -4.724436000 & -0.620675000 \\
\hline $\mathrm{O}$ & -2.276246000 & -2.440847000 & -1.716275000 \\
\hline C & -4.604782000 & -3.538498000 & -1.008845000 \\
\hline $\mathrm{H}$ & -5.012248000 & -4.154360000 & -0.203874000 \\
\hline $\mathrm{H}$ & -5.029963000 & -2.532145000 & -0.997970000 \\
\hline $\mathrm{H}$ & -4.746478000 & -4.015646000 & -1.982770000 \\
\hline $\mathrm{H}$ & -2.549028000 & -4.529554000 & 1.916119000 \\
\hline $\mathrm{H}$ & -3.283986000 & -2.994542000 & 4.033983000 \\
\hline $\mathrm{H}$ & -3.693712000 & -0.483128000 & 3.045570000 \\
\hline C & 3.043760000 & -2.905617000 & 0.587132000 \\
\hline C & 4.318061000 & -3.105806000 & 0.050268000 \\
\hline
\end{tabular}




$\begin{array}{lrrr}\text { H } & 5.027885000 & -3.721482000 & 0.590470000 \\ \text { H } & 2.783107000 & -3.361693000 & 1.538516000 \\ \text { H } & 1.729056000 & -0.896250000 & -1.828770000 \\ \text { H } & 3.978663000 & -1.269570000 & -2.797466000 \\ \text { H } & 7.756892000 & -3.392428000 & -1.794614000 \\ \text { H } & 7.138060000 & -3.009842000 & -0.160789000 \\ \text { H } & 6.555082000 & -4.470425000 & -1.025973000 \\ \text { C } & -0.083812000 & 0.424056000 & 2.264374000 \\ \text { C } & 1.341027000 & 0.881198000 & 2.146401000 \\ \text { C } & 0.860064000 & -0.447347000 & 2.615848000 \\ \text { H } & 1.115786000 & -1.306013000 & 3.219598000 \\ \text { C } & 2.124010000 & 1.281120000 & 0.873517000 \\ \text { H } & 1.527565000 & 1.469982000 & -0.022137000 \\ \text { H } & 2.922650000 & 0.575966000 & 0.620786000 \\ \text { C } & 2.642926000 & 2.538831000 & 1.628154000 \\ \text { H } & 2.121394000 & 3.446103000 & 1.298179000 \\ \text { C } & 2.035415000 & 1.997337000 & 2.960092000 \\ \text { H } & 2.780865000 & 1.612201000 & 3.669457000 \\ \text { H } & 1.369818000 & 2.683629000 & 3.498506000 \\ \text { C } & 4.133739000 & 2.840818000 & 1.574910000 \\ \text { H } & 4.372160000 & 3.683644000 & 2.239887000 \\ \text { O } & 4.978307000 & 1.717775000 & 1.901967000 \\ \text { H } & 4.838283000 & 1.486646000 & 2.835340000 \\ \text { H } & 4.419209000 & 3.121121000 & 0.555162000 \\ \text { H } & -1.077155000 & 0.782132000 & 2.502749000 \\ \text { P-Sph } & & & \\ & & & \\ & & \end{array}$




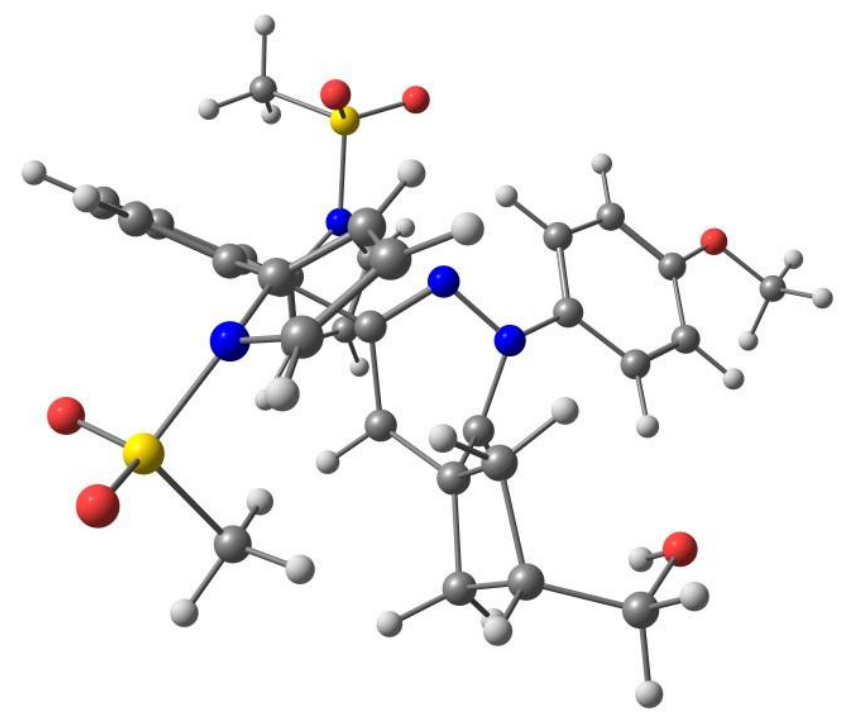

Figure S30. NI-Sph product. The geometry was optimized at the B3LYP-D3/6-31+G(d)/SMD(water) level of theory.

$\begin{array}{llll}\text { C } & -7.458429000 & -2.959103000 & -0.474965000 \\ \text { O } & -6.770946000 & -1.755102000 & -0.837310000 \\ \text { C } & -5.404932000 & -1.705683000 & -0.637586000 \\ \text { C } & -4.774061000 & -0.505036000 & -0.991810000 \\ \text { C } & -3.403156000 & -0.346470000 & -0.815172000 \\ \text { C } & -2.626199000 & -1.397960000 & -0.296713000 \\ \text { N } & -1.234081000 & -1.271696000 & -0.107979000 \\ \text { N } & -0.608669000 & -0.123108000 & -0.566179000 \\ \text { C } & 0.400725000 & 0.149925000 & 0.205280000 \\ \text { C } & 1.144434000 & 1.433436000 & 0.095117000 \\ \text { C } & 0.590565000 & 2.560347000 & 0.744598000 \\ \text { C } & 1.288745000 & 3.771477000 & 0.767975000 \\ \text { C } & 2.525124000 & 3.882167000 & 0.126669000 \\ \text { C } & 3.060077000 & 2.784488000 & -0.541334000 \\ \text { C } & 2.386848000 & 1.550091000 & -0.558300000 \\ \text { C } & 2.937463000 & 0.429410000 & -1.345740000 \\ \text { C } & 2.402778000 & -0.168233000 & -2.462758000 \\ \text { C } & 3.341361000 & -1.118419000 & -2.974777000 \\ \text { C } & 4.441079000 & -1.098879000 & -2.161811000 \\ \text { N } & 4.234218000 & -0.117795000 & -1.180227000 \\ \text { S } & 5.138278000 & -0.166621000 & 0.281412000 \\ \text { O } & 5.102610000 & 1.173053000 & 0.881143000\end{array}$




$\begin{array}{llll}\mathrm{O} & 6.439846000 & -0.747513000 & -0.087069000 \\ \mathrm{C} & 4.231153000 & -1.307332000 & 1.317103000 \\ \mathrm{H} & 4.185357000 & -2.269819000 & 0.805082000 \\ \mathrm{H} & 3.236940000 & -0.890034000 & 1.479563000 \\ \mathrm{H} & 4.782894000 & -1.385120000 & 2.258272000 \\ \mathrm{H} & 5.357083000 & -1.669567000 & -2.181044000 \\ \mathrm{H} & 3.217927000 & -1.741845000 & -3.850929000 \\ \mathrm{H} & 1.439773000 & 0.085487000 & -2.885547000 \\ \mathrm{H} & 4.007482000 & 2.874976000 & -1.062755000 \\ \mathrm{H} & 3.062246000 & 4.826385000 & 0.137273000 \\ \mathrm{H} & 0.856517000 & 4.626776000 & 1.279963000 \\ \mathrm{C} & -0.725230000 & 2.436567000 & 1.416637000 \\ \mathrm{C} & -1.025868000 & 1.976929000 & 2.675669000 \\ \mathrm{C} & -2.450301000 & 1.954529000 & 2.830865000 \\ \mathrm{C} & -3.005759000 & 2.401223000 & 1.662243000 \\ \mathrm{~N} & -1.958811000 & 2.679293000 & 0.777102000 \\ \mathrm{~S} & -2.219978000 & 3.535594000 & -0.681548000 \\ \mathrm{O} & -3.601270000 & 3.219479000 & -1.079590000 \\ \mathrm{O} & -1.120431000 & 3.209131000 & -1.597804000 \\ \mathrm{C} & -2.116740000 & 5.253896000 & -0.192261000 \\ \mathrm{H} & -1.422376000 & -2.902296000 & -0.313481000 \\ \mathrm{H} & -2.865672000 & 5.426428000 & 0.583827000 \\ \mathrm{H} & -1.106784000 & 5.444289000 & 0.176135000 \\ \mathrm{H} & -2.328606000 & 5.850826000 & -1.083939000 \\ \mathrm{H} & -4.033094000 & 2.542748000 & 1.362223000 \\ \mathrm{H} & -3.001314000 & 1.628258000 & 3.703609000 \\ \mathrm{H} & -0.288124000 & 1.649911000 & 3.397185000 \\ \mathrm{C} & -3.259957000 & -2.602267000 & 0.041607000 \\ \mathrm{C} & -4.641938000 & -2.756467000 & -0.115199000 \\ \mathrm{H} & -5.097951000 & -3.700221000 & 0.161185000 \\ \mathrm{H} & -2.675083000 & -3.435109000 & 0.421467000 \\ \mathrm{H} & -2.935789000 & 0.594985000 & -1.071029000 \\ \mathrm{H} & -5.371051000 & 0.312051000 & -1.387857000 \\ \mathrm{H} & -7.510279000 & -2.779087000 & -0.704235000 \\ \mathrm{H} & -7.345907000 & -3.169978000 & 0.595575000 \\ \mathrm{H} & -1.594127000 & -0.815846000 & 1.309933000 \\ \mathrm{H} & -2.361915000 & -0.688692000 \\ \mathrm{H} & -3.086379000 & -1.143388000\end{array}$




$\begin{array}{llll}\text { C } & 1.796897000 & -4.142090000 & 0.558707000 \\ \text { H } & 2.858633000 & -4.411616000 & 0.523433000 \\ \text { C } & 1.391348000 & -3.351392000 & 1.844749000 \\ \text { H } & 0.679412000 & -3.843685000 & 2.520450000 \\ \text { H } & 2.252179000 & -3.013093000 & 2.431213000 \\ \text { C } & 0.990201000 & -5.404375000 & 0.282129000 \\ \text { H } & 1.186118000 & -6.150541000 & 1.065955000 \\ \text { O } & -0.430657000 & -5.183537000 & 0.168388000 \\ \text { H } & -0.762355000 & -4.806521000 & 1.000988000 \\ \text { H } & 1.285988000 & -5.832109000 & -0.681515000 \\ \text { H } & 0.930969000 & -0.465289000 & 2.283506000\end{array}$

